UNIVERSIDADE DE SÃO PAULO

FACULDADE DE ECONOMIA, ADMINISTRAÇÃO E CONTABILIDADE DEPARTAMENTO DE ADMINISTRAÇÃO

PROGRAMA DE MESTRADO PROFISSIONAL EM EMPREENDEDORISMO

RUI SÉRGIO TORRES

Estudo de Impacto do Programa de Treinamento

Comportamental em Empreendedorismo - EMPRETEC 
Prof. Dr. Vahan Agopyan

Reitor da Universidade de São Paulo

Prof. Dr. Adalberto Américo Fischmann

Diretor da Faculdade de Economia, Administração e Contabilidade

Prof. Dr. Moacir de Miranda Oliveira Jr.

Chefe do Departamento de Administração

Prof. Dr. Marcelo Caldeira Pedroso

Coordenador do Programa de Mestrado Profissional em Empreendedorismo 
RUI SÉRGIO TORRES

\title{
Estudo de Impacto do Programa de Treinamento Comportamental em Empreendedorismo - EMPRETEC
}

\author{
Versão Corrigida
}

Dissertação apresentada ao programa de Mestrado Profissional em Empreendedorismo do Departamento de Administração da Faculdade de Economia, Administração e Contabilidade da Universidade de São Paulo, como requisito parcial para a obtenção do grau de Mestre em Ciências.

Orientadora: Profa. Dra. Lisete Barlach 

Elaborada por Rafael Mielli Rodrigues - CRB-8/7286

Seção de Processamento Técnico do SBD/FEA/USP

Torres, Rui Sérgio

Estudo de impacto do programa de treinamento comportamental em empreendedorismo - Empretec / Rui Sérgio Torres. - São Paulo, 2018. $137 \mathrm{p}$.

Dissertação (Mestrado) - Universidade de São Paulo, 2018.

Orientador: Lisete Barlach.

1. Empreendedorismo 2. Educação empreendedora 3. Comportamentos empreendedores I. Universidade de São Paulo. Faculdade de Economia, Administração e Contabilidade. II. Título.

CDD -658.421 
À minha esposa Moema e às minhas filhas Carolina e Maria Luiza, por sua presença, força e amor.

Aos meus pais, Jonas e Zélia, e aos meus sogros, Marco e Ruth, pelos inúmeros ensinamentos e exemplos de caráter, honestidade, bondade e fé. 



\section{AGRADECIMENTOS}

Um agradecimento especial à minha família, Moema, Carolina e Maria Luiza, pela compreensão nas ausências e por terem me apoiado durante esse projeto tão desafiador.

Aos meus sócios, Rossana e Francesco, pela aceitação e apoio incondicionais.

À minha orientadora, Profa. Dra. Lisete Barlach, pelos inúmeros ensinamentos, presença constante, e supervisão serena.

Aos queridos colegas da turma 3 do Mestrado Profissional em Empreendedorismo da FEAUSP, pela companhia, apoio mútuo, alegria, inteligência e capacidade de realizar.

Aos professores do Mestrado Profissional em Empreendedorismo, pela dedicação, capacidade e informações tão preciosas compartilhadas ao longo dessa jornada.

À equipe da FEA-USP responsável pelo programa de Mestrado Profissional em Empreendedorismo, em especial a Fabiana Caseiro, por sua atenção, carinho e preocupação.

Aos amigos Marcos e Mauro Pedro Lopes, pelas inúmeras trocas de informações, apoio, e por permitirem o acesso a pessoas, dados e conteúdo bibliográfico que muito me ajudaram nesse projeto.

Aos amigos Ana Lúcia Emmerich e Paulo Valery, por compartilharem informações e bancos de dados que ajudaram a viabilizar a pesquisa.

À Profa. Sumaia Latif, pelos ensinamentos em estatística, que me ajudaram a compreender as limitações e desafios deste estudo.

Aos mais de trezentos empretecos que participaram da pesquisa, por sua disponibilidade de tempo e disposição em ajudar.

A todas as pessoas que, de uma forma ou de outra, me ajudaram nessa desafiante caminhada. 



\section{RESUMO}

TORRES, Rui Sérgio. Estudo De Impacto Do Programa De Treinamento Comportamental Em Empreendedorismo - EMPRETEC, 2018. 99 p. Dissertação (Mestrado Profissional em Empreendedorismo) - Departamento de Administração da Faculdade de Economia, Administração e Contabilidade da Universidade de São Paulo, 2018.

O empreendedorismo é um tema que atrai cada vez mais interessados, por diferentes razões, em contextos e realidades distintos. Valorizar e apoiar esse fenômeno torna-se essencial para o sucesso econômico e social, não só do Brasil, mas de todo o mundo. Uma das formas de apoio é através de programas de educação empreendedora. Esse estudo visou compreender fatores determinantes para o empreendedorismo, tendo o empreendedor como foco nessas discussões, bem como aspectos comportamentais envolvidos nesse processo, e a efetividade de programas de educação empreendedora. Talvez um dos programas mais aplicados em educação empreendedora, o EMPRETEC é um grande símbolo quando se trata desse assunto. Ao longo dos seus trinta anos de existência, estando presente no Brasil há vinte e cinco, mais de trezentos e cinquenta mil pessoas passaram pelo programa, das quais duzentos e cinquenta mil somente no Brasil. Entretanto, o programa sofreu mudanças no seu formato, conteúdo e duração. Estudos anteriores já haviam demonstrado a efetividade do EMPRETEC, mas não havia disponível nenhum estudo relativo à última mudança, ocorrida em 2011. O presente estudo visou avaliar o impacto desse programa, sob o ponto de vista da efetiva prática dos comportamentos empreendedores, e investigar como no dia a dia os empreendedores os praticam. A partir dos dados obtidos, é possível concluir que os participantes do EMPRETEC adotam a prática efetiva dos comportamentos preconizados pelo programa, e consideram que o EMPRETEC fez diferença em suas jornadas empreendedoras. Uma vez que a presente pesquisa tomou como base a autopercepção dos próprios empreendedores(as), sugere-se a continuidade de estudos sobre este e outros programas de educação empreendedora que sejam capazes de avaliar a prática de comportamentos e seu impacto nos resultados do empreendimento para além da narrativa dos participantes

Palavras-chave: Empreendedorismo. Educação Empreendedora. Comportamentos Empreendedores. 


\begin{abstract}
TORRES, Rui Sérgio. Impact study of the Behavioral Training Program in entrepreneurship - EMPRETEC, 2018. 99 p. Dissertação (Mestrado Profissional em Empreendedorismo) - Departamento de Administração da Faculdade de Economia, Administração e Contabilidade da Universidade de São Paulo, 2018.

Entrepreneurship is a theme that attracts more and more interested, for different reasons, in distinct contexts and realities. Appreciating and supporting this phenomenon is essential for economic and social success, not only for Brazil, but for most countries of the world. One of the ways of supporting is through entrepreneurial educational programs. This study aimed to understand determinant factors for entrepreneurship, having the entrepreneur as a focus on these discussions, as well as behavioral aspects involved in this process, and the effectiveness of entrepreneurial educational programs. Perhaps one of the most famous programs in entrepreneurial education, the EMPRETEC is a great symbol when it comes to this issue. Throughout its thirty years of existence, being present in Brazil for twenty-five, over threehundred and fifty thousand people have attended the program, two-hundred and fifty thousand from Brazil alone. However, it has undergone changes in its format, content and duration. Previous studies had already demonstrated the effectiveness of the EMPRETEC, but no study was available concerning the last change, which occurred in 2011. This study aimed to assess the impact of this program, from the point of view of the effective practice of entrepreneurial behaviors, and to investigate how in everyday life, entrepreneurs practice them. From the data obtained, it is possible to conclude that the participants of the EMPRETEC adopt the effective practice of the behaviors advocated by the program and consider that the EMPRETEC made a difference in their entrepreneurial journeys. As the present research was based on the selfperception of the entrepreneurs, future studies could evaluate the behavioral performance throughout other methods beyond these narratives.
\end{abstract}

Keywords: Entrepreneurship. Entrepreneurial Education. Entrepreneurial Behaviors 


\section{LISTA DE SIGLAS}

BOS Behavioural Observation Scale

CCE Características de Comportamento Empreendedor

FNQ Fundação Nacional para a Qualidade

GEM Global Entrepreneurship Monitor

IBGE Instituto Brasileiro de Geografia e Estatística

MEG Modelo para a Excelência da Gestão

MP Mestrado Profissional

MPE Micro e Pequenas Empresas

MSI Management Systems International

ONU Organização das Nações Unidas

PIB Produto Interno Bruto

PME Pequenas e Médias Empresas

SEBRAE Serviço Brasileiro de Apoio às Micro e Pequenas Empresas

TMR Treinamento de Motivação para a Realização

UNCTAD United Nations Conference On Trade And Development

USAID Agência dos Estados Unidos para o Desenvolvimento Internacional 


\section{LISTA DE QUADROS}

Quadro 1 - Taxas de Empreendedorismo por oportunidade e por necessidade.........................24

Quadro 2 - Características de Comportamento Empreendedor............................................28

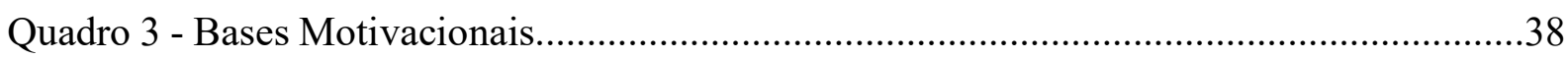

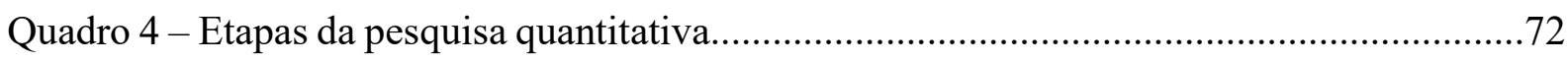

Quadro 5 - Empreendedores estabelecidos por setor da atividade econômica...........................75

Quadro 6 - Enquadramento de empresas por faixa de faturamento.......................................76

Quadro 7 - Percentual de empreendedores estabelecidos por gênero......................................80

Quadro 8 - Distribuição dos empreendedores estabelecidos (TEE) por faixa etária..................81

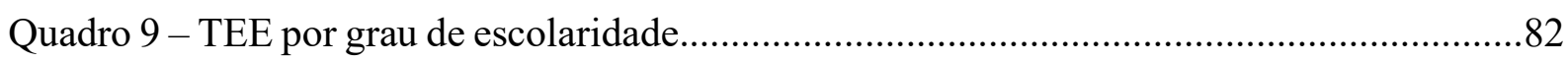




\section{LISTA DE TABELAS}

Tabela 1 - Áreas de conhecimento a serem investigadas....................................................36

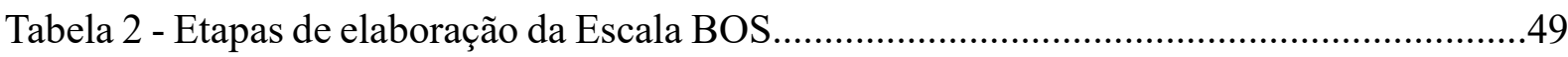

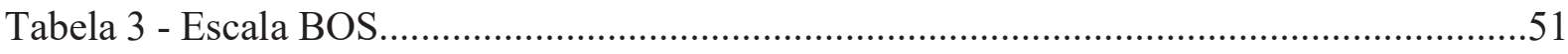

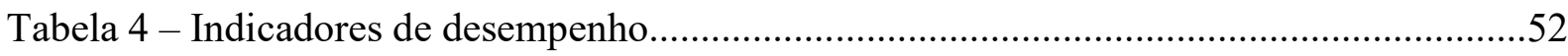

Tabela 5 - Comportamentos utilizados no segundo questionário...........................................63

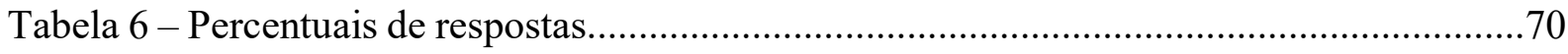

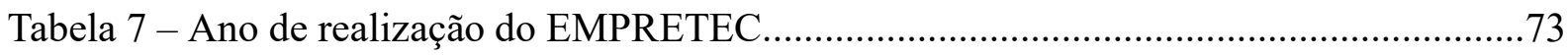

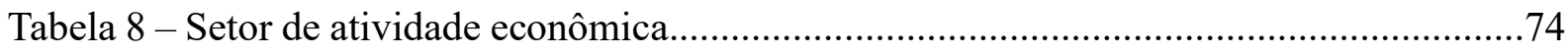

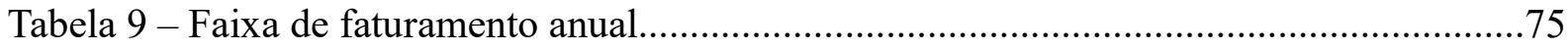

Tabela 10 - Número de colaboradores - antes e depois do EMPRETEC .................................77

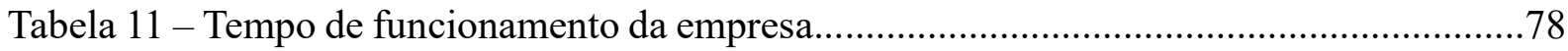

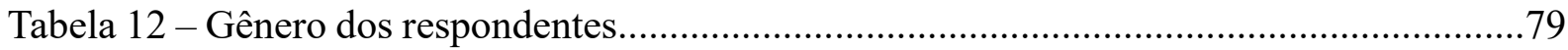

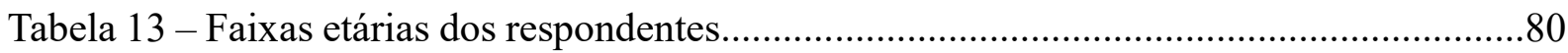

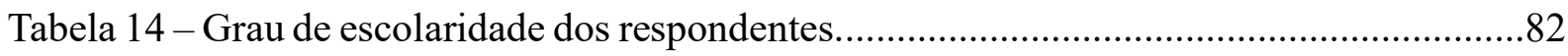

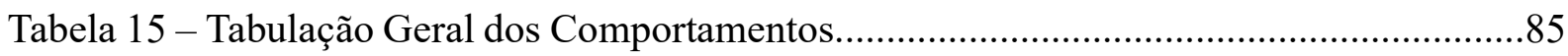

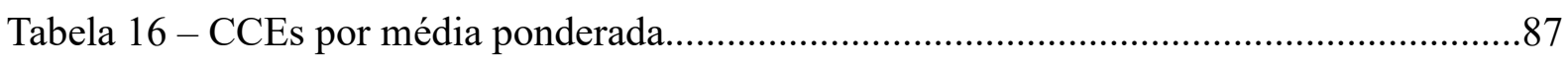

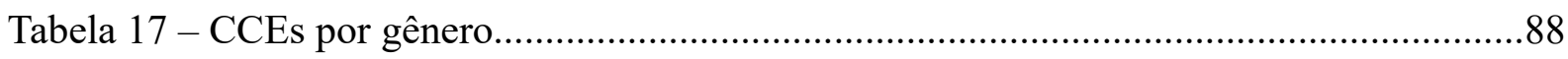

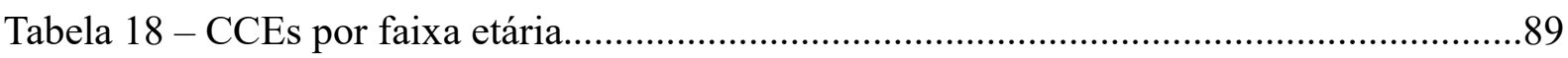

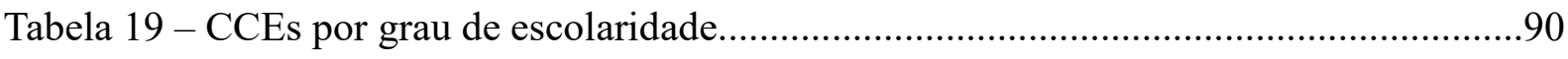

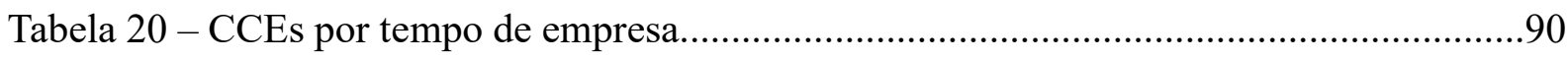

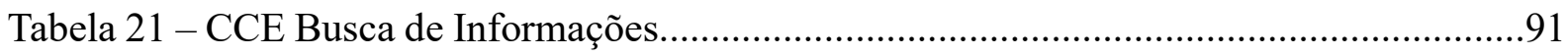

Tabela 22 - CCE Busca de Informações..........................................................................

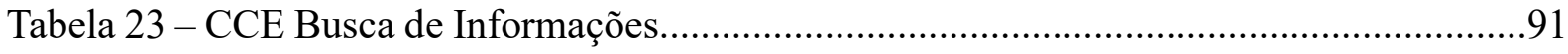

Tabela 24 - CCE Busca de Oportunidades e Iniciativa.......................................................92 


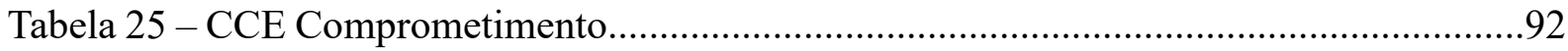

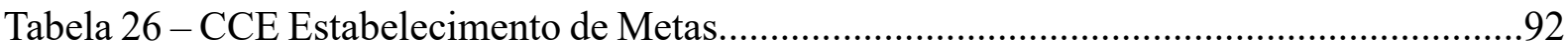

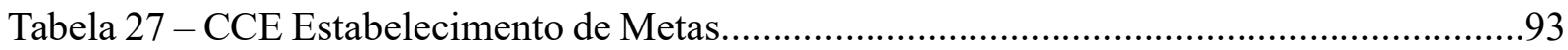

Tabela 28 - CCE Planejamento e Monitoramento Sistemático................................................93

Tabela 29 - CCE Planejamento e Monitoramento Sistemático.................................................93

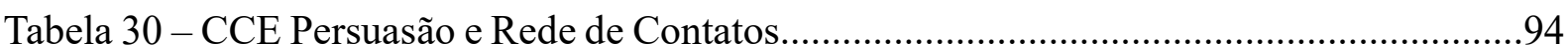




\section{LISTA DE GRÁFICOS}

Gráfico 1 - Ano de realização do EMPRETEC ...................................................................... 72

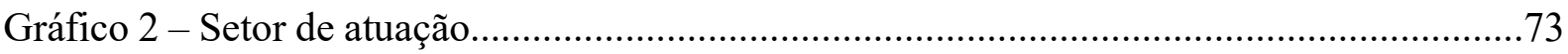

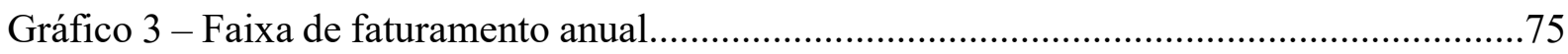

Gráfico 4 - Número de colaboradores ANTES e APÓS o EMPRETEC....................................76

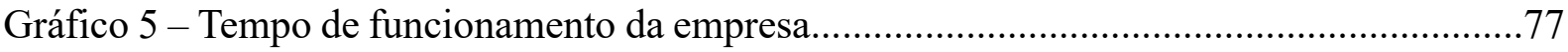

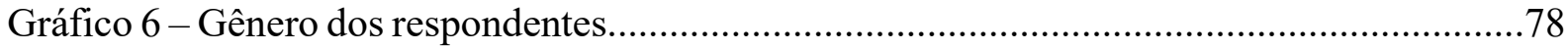

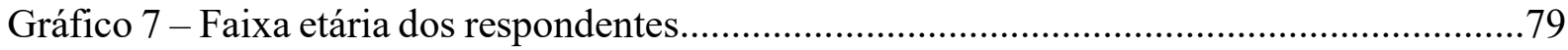

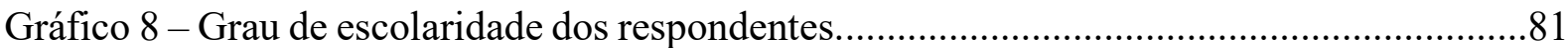




\section{LISTA DE FIGURAS}

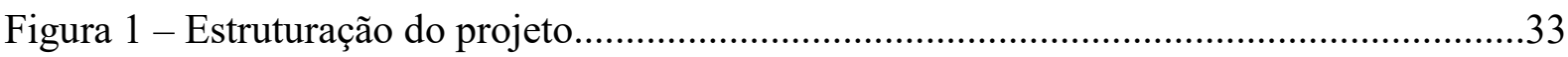

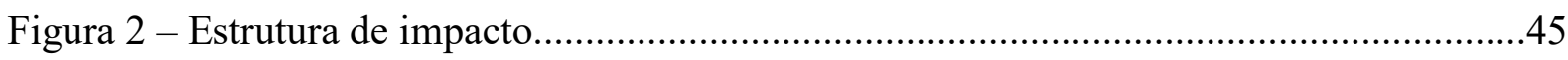

Figura 3 - Ciclo para elaboração de pesquisas...................................................................56

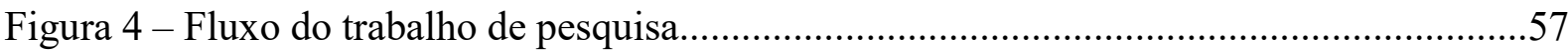




\section{SUMÁRIO}

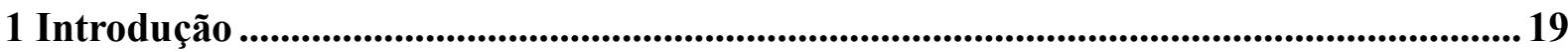

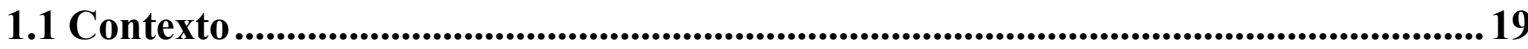

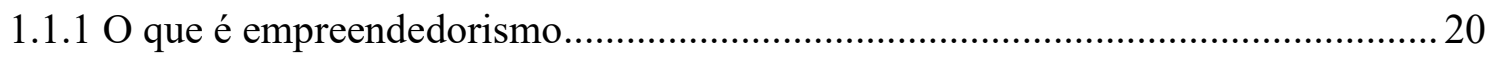

1.1.2 Fatores e elementos determinantes para o empreendedorismo ............................. 22

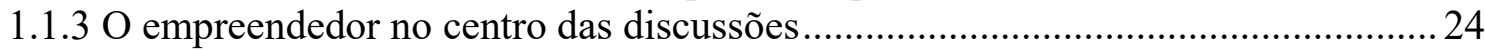

1.2 Relato da experiência (EMPRETEC) ........................................................................... 27

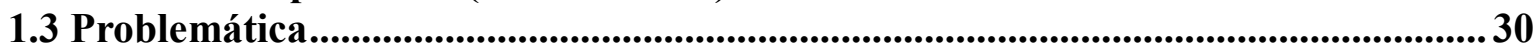

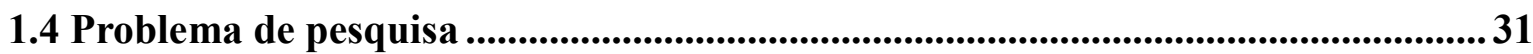

1.5 Objetivos da Pesquisa .......................................................................................... 31

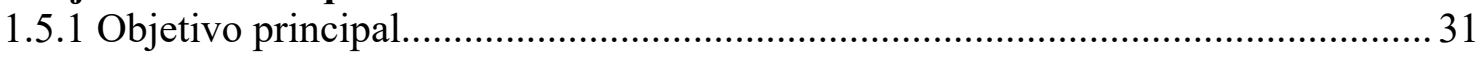

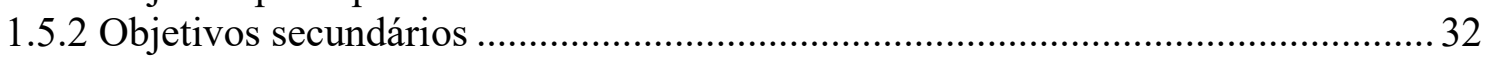

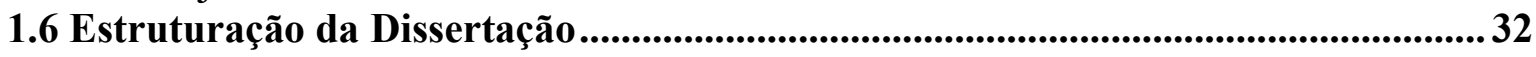

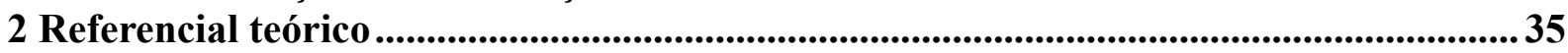

2.1 Teorias Comportamentais sobre empreendedorismo .............................................37

2.2 Educação Empreendedora .....................................................................................................40

2.3 Avaliação de impacto em programas de educação empreendedora .......................... 45

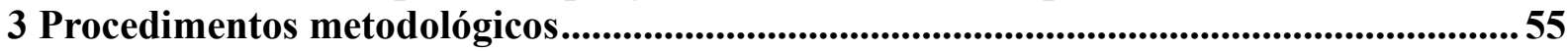

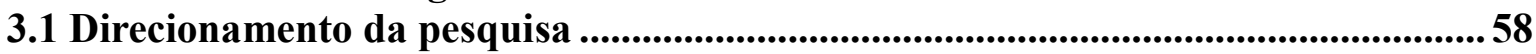

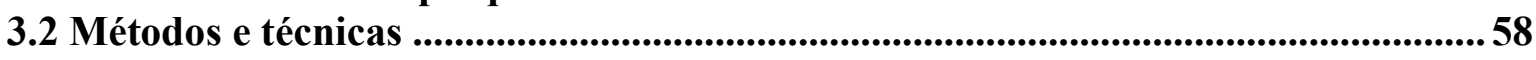

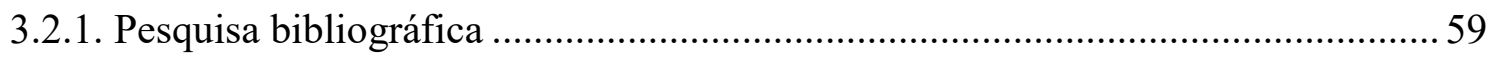

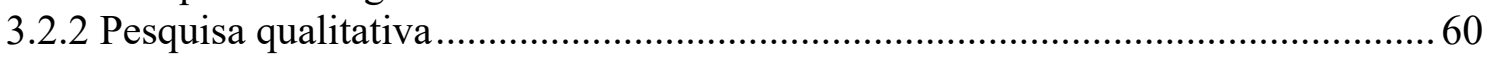

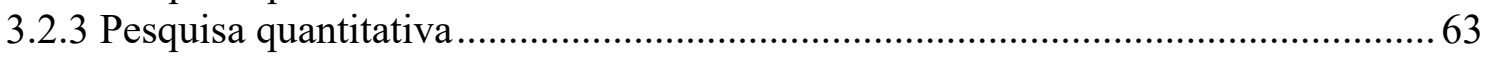

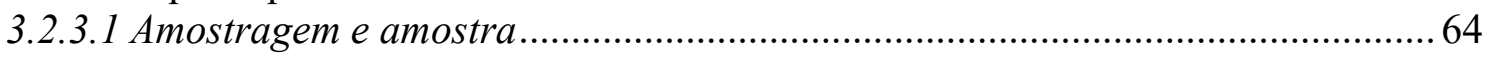

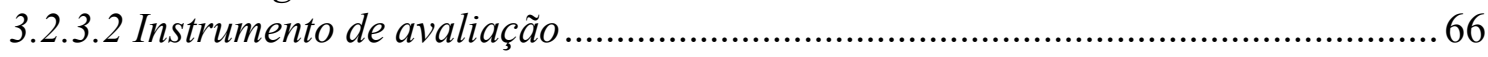

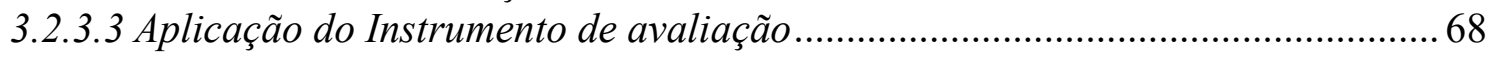

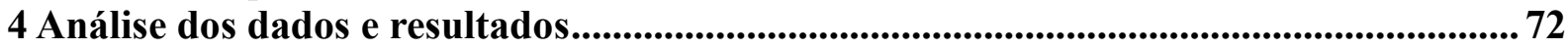

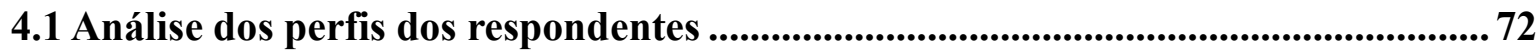

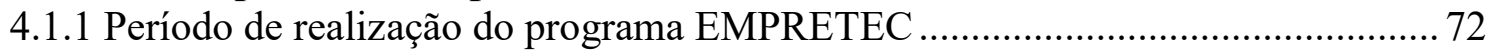

4.1.2 Dados sobre os empreendimentos dos respondentes ............................................. 74

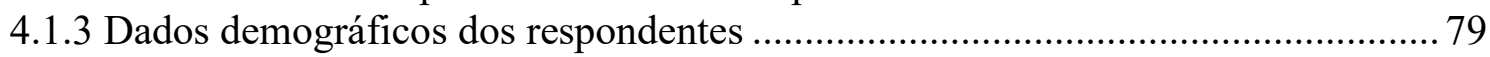

4.2 Comportamentos Empreendedores.......................................................................................... 84

4.3 Práticas de gestão ....................................................................................................90

5 Conclusões, limitações e sugestões para pesquisas futuras...........................................95

5.1 Limitações.................................................................................................................................98

5.2 Sugestões para pesquisas futuras .......................................................................................99

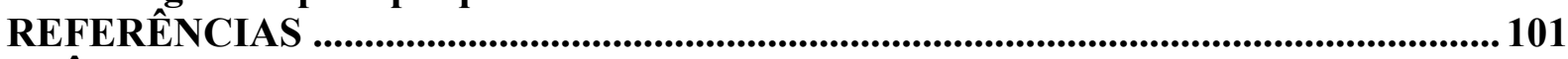

APÊNDICE A - Formulário da Pesquisa Qualitativa......................................................... 105

APÊNDICE B - Formulário Pesquisa Quantitativa .......................................................111

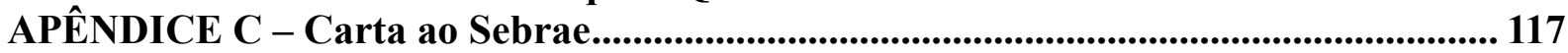

ANEXO A - Resposta do Sebrae ................................................................................................ 118

ANEXO B - Relatório da Consulta ao CEA - IME/USP............................................ 119 




\section{INTRODUÇÃO}

\subsection{Contexto}

\section{"A era dos Empreendedores"}

Esse é o título de um dos módulos do programa de treinamento comportamental para empreendedores, o EMPRETEC ${ }^{1}$, objeto desse estudo. Cada vez mais o tema empreendedorismo é recorrente, não só no Brasil, mas em todo o mundo. Embora não seja recente, esse fenômeno chamado empreendedorismo atrai cada vez mais interessados, sob diferentes pontos de vista e perspectivas.

Como destaca Lopes (1999), em sua dissertação de Mestrado, "Como uma contraofensiva ao desemprego, notam-se esforços tanto de governos, de agências e organismos internacionais, quanto dos próprios indivíduos no esforço para criar renda e empregos, com o estabelecimento de Pequenas e Médias Empresas" (LOPES, 1999, p. 5).

Estatísticas de diversos países apontam o crescimento de pequenos e médios empreendimentos, em proporção bem superior ao crescimento das economias em geral, bem como o aumento da importância dos pequenos e médios empreendimentos na geração de empregos e no bem-estar dos cidadãos em geral.

O SEBRAE - Serviço Brasileiro de Apoio às Micro e Pequenas Empresas, entidade que "promove a competitividade e o desenvolvimento sustentável dos empreendimentos de micro e pequeno porte no Brasil" (SEBRAE, 2017), apontou, em um dos diversos estudos que faz, que o número de micro e pequenas empresas (MPEs) cresceu 27,5\% entre 2005 e 2015 (SEBRAE, 2017), e os empregos formais nas MPEs cresceram 55,3\% nesse mesmo período (SEBRAE, 2017).

\footnotetext{
${ }^{1}$ EMPRETEC é um programa de mudança comportamental autodirigida, aplicado em diversos países no mundo, aqui no Brasil com exclusividade pelo SEBRAE. Note-se de que não se trata de acrônimo ou sigla, sendo esse o nome do programa.
} 
Instituições como o GEM - Global Entrepreneur Monitor, um consórcio que tem como fundadores Babson College, dos EUA, e London Business School, do Reino Unido, além de entidades mantenedoras, como Universidad del Desarollo, do Chile, e Tecnológico de Monterrey, do México, vêm acompanhando o desenvolvimento do empreendedorismo em diversos continentes, em inúmeros países, de diferentes culturas e nível de desenvolvimento econômico, traçando com isso um amplo painel do empreendedorismo no mundo.

Segundo o SEBRAE, a relevância dos pequenos empreendimentos é cada vez maior. A participação das MPEs no Produto Interno Bruto (PIB) brasileiro também vem apresentando significativo aumento nos últimos anos. Ainda de acordo com o SEBRAE,

\footnotetext{
As Micro e Pequenas empresas (doravante MPE) vêm adquirindo, ao longo dos últimos 30 anos, uma importância crescente no país, sendo inquestionável o seu relevante papel socioeconômico desempenhado. Em estudo anteriormente publicado, tal importância no âmbito nacional dimensiona essa afirmativa, ao constatar que as MPE geraram, em 2011, 27\% do Valor Adicionado do conjunto de atividades pesquisadas (PIB), tendo sido observado uma elevação desse percentual quando comparado aos anos anteriores, quando representava $21 \%$ em 1985 e $23,2 \%$ em 2001 (SEBRAE, 2017).
}

A importância do empreendedorismo no Brasil é cada vez maior, como observado pelo GEM. De acordo com o relatório Empreendedorismo no Brasil (GEM, 2015), a taxa total de empreendedorismo (TTE) para o Brasil foi de 39,3\%, observando ainda que essa taxa apresentou aumento significativo em relação a 2014, "intensificando a trajetória de crescimento observada desde 2011" (GEM, 2015, p. 9).

Este mesmo relatório apresenta que 77,7\% dos entrevistados "concordam que no Brasil a maioria das pessoas considera que abrir um negócio é uma opção viável de carreira" (GEM, 2015, p. 17).

Em comparação com outros países, a China apresenta um índice de 26,7\%, os EUA 20\%, a Índia 10,2\%, e a Rússia 8,6\%. Percebe-se, portanto, que, em diferentes países, o tema é cada vez mais presente, estudado, analisado e debatido.

\subsubsection{O que é empreendedorismo}


Para entender melhor o que é o empreendedorismo e o que significa empreender, é necessário buscar conceitos e definições sobre o tema. Existem diversas definições, conceitos e contextos que abrangem o empreendedorismo, sob diferentes pontos de vista.

As primeiras definições de empreendedorismo e empreendedores remontam ao século XVIII. Segundo Morales (2004, p. 24): "Em 1755, Richard Cantillon identificou o empreendedor como sendo quem assume riscos no processo de comprar serviços ou componentes por um certo preço com a intenção de revendê-los mais tarde por um preço incerto".

Outra importante definição de empreendedorismo é apresentada pelo GEM: “O Empreendedorismo consiste em qualquer tentativa de criação de um novo negócio ou novo empreendimento, como, por exemplo: uma atividade autônoma, uma nova empresa ou a expansão de um empreendimento existente" (GEM, 2015, p. 7).

Uma definição bastante abrangente é dada por Lopes (1999):

Um empreendedor é um indivíduo que identifica oportunidades, e para explorá-la toma a iniciativa de reunir, organizar e/ou administrar recursos na forma de uma empresa autônoma, assumindo uma quantidade significativa de risco associado com a participação acionária da empresa, e envolvendo-se e comprometendo-se pessoalmente com seus resultados (LOPES, 1999, p. 35).

Barlach (2009) entende que "o desenvolvimento de competências empreendedoras deve abranger o chamado ciclo de negócios, a saber, criatividade, reconhecimento de oportunidade, invenção ou descoberta de um produto ou serviço, avaliação da oportunidade de negócio, construção do mercado, e do sistema de entrega, crescimento e renovação" (BARLACH, 2009, p. 157).

Empreendedores são, em sua essência, construtores. De sonhos, ideias, projetos, resultados, sucesso, e realização, tanto para si, quanto para os que os cercam.

Além dessas, há inúmeras outras definições sobre o que é empreendedorismo. Pode-se, então, a partir dessas definições, resumir o ato de empreender como sendo:

a) Assumir riscos;

b) Identificar oportunidades; 

c) Saber planejar;
d) Ter criatividade;
e) Ter iniciativa;
f) Comprometer-se e envolver-se

para criar um negócio ou empreendimento. Uma vez dominados esses fatores, poder-se-ia imaginar que as chances de o empreendimento dar certo são altas.

Entretanto, a despeito de um avanço nos números referentes à taxa de mortalidade das empresas após 2 anos de sua fundação, segundo o SEBRAE (SEBRAE, 2017), a realidade mostra que, após 5 anos, 62,2\% das empresas acaba fechando (IBGE, 2017).

Especialistas consultados "apontam melhoras consistentes nos últimos anos" (GEM, 2015), mas ainda consideram políticas públicas como "a principal condição limitante ao empreendedorismo no Brasil" (GEM, 2015, p. 18).

Ainda assim, e a despeito da falta de políticas públicas claras e duradouras, há empreendimentos alcançando resultados, mesmo diante de obstáculos e desafios.

Entender, portanto, porque alguns empreendimentos dão certo, prosperam, geram empregos, lucros para seus proprietários, enquanto outros não, é crucial para compreender diversos contextos e situações, e estabelecer políticas e programas que possam colaborar com a geração de mais empreendimentos no Brasil, além do aperfeiçoamento na gestão dos já existentes.

Antes, porém, é necessário analisar fatores e elementos que determinam o empreendedorismo, apresentando diferentes perspectivas sobre esse assunto.

1.1.2 Fatores e elementos determinantes para o empreendedorismo

Schumpeter (1949), considerado um dos mais importantes economistas da primeira metade do século XX, e McClelland (1958), psicólogo de Harvard, cujas pesquisas iniciais identificaram que pessoas motivadas pela autorrealização, “tornam-se referências clássicas para a discussão de distintas perspectivas sobre os determinantes do empreendedorismo" (ALVIM, 2008, p. 25). 
De um lado, analisando o aspecto econômico dos empreendimentos, e a realidade econômica na qual estavam inseridos, e atribuindo a estes fatores as razões de sucesso (ou insucesso) dos empreendimentos em geral (SCHUMPETER, 1949), e, de outro, teorias comportamentais, entre as quais se destaca a de McClelland (1958), na qual o empreendedor e seu comportamento representam papel central no sucesso (ou fracasso) de seu empreendimento.

Essas duas linhas de pensamento contrapõem aspectos externos, como realidade e desenvolvimento econômico de uma região, ou mesmo de um país, com aspectos internos, nos quais o papel do empreendedor e suas ações são causa dos seus resultados.

Como esse trabalho visa entender o impacto de um programa de treinamento que trabalha aspectos comportamentais dos empreendedores, é importante trazer o papel do empreendedor para o centro das discussões.

Embora não haja estatísticas disponíveis a esse respeito, sabe-se que os chamados empreendedores considerados natos, aqueles que empreendem em quaisquer circunstâncias ou situações, representam uma pequeníssima parcela da população "empreendedora". A maioria dos empreendedores tem o desejo de empreender desencadeado por outras questões, e toma a decisão de empreender em algum momento de sua vida, e por razões e motivos distintos e bastante contextualizados.

Barlach (2009) destaca que "os aspectos emancipatórios do empreendedorismo estão ligados aos sonhos e esforços para criar mudanças no mundo" (BARLACH, 2009, p. 161). Destaca-se aí o empreendedorismo por oportunidade, em que o empreendedor vislumbra uma oportunidade num determinado mercado e decide explorá-la.

Existe também o empreendedorismo por necessidade, em que o candidato a empreendedor acaba sendo levado a empreender para gerar um resultado financeiro que o permita sustentar sua família. Este tipo de empreendedorismo surge de maneira mais forte em momentos de crise, quando as taxas de desemprego são altas, e as perspectivas econômicas, ruins. 
O relatório do GEM (GEM, 2016) apresenta um quadro que ilustra bem a contextualização de empreendedorismo por oportunidade x por necessidade, em função da realidade econômica do Brasil ao longo de diversos anos.

Quadro 1 - Taxas de Empreendedorismo por oportunidade e por necessidade

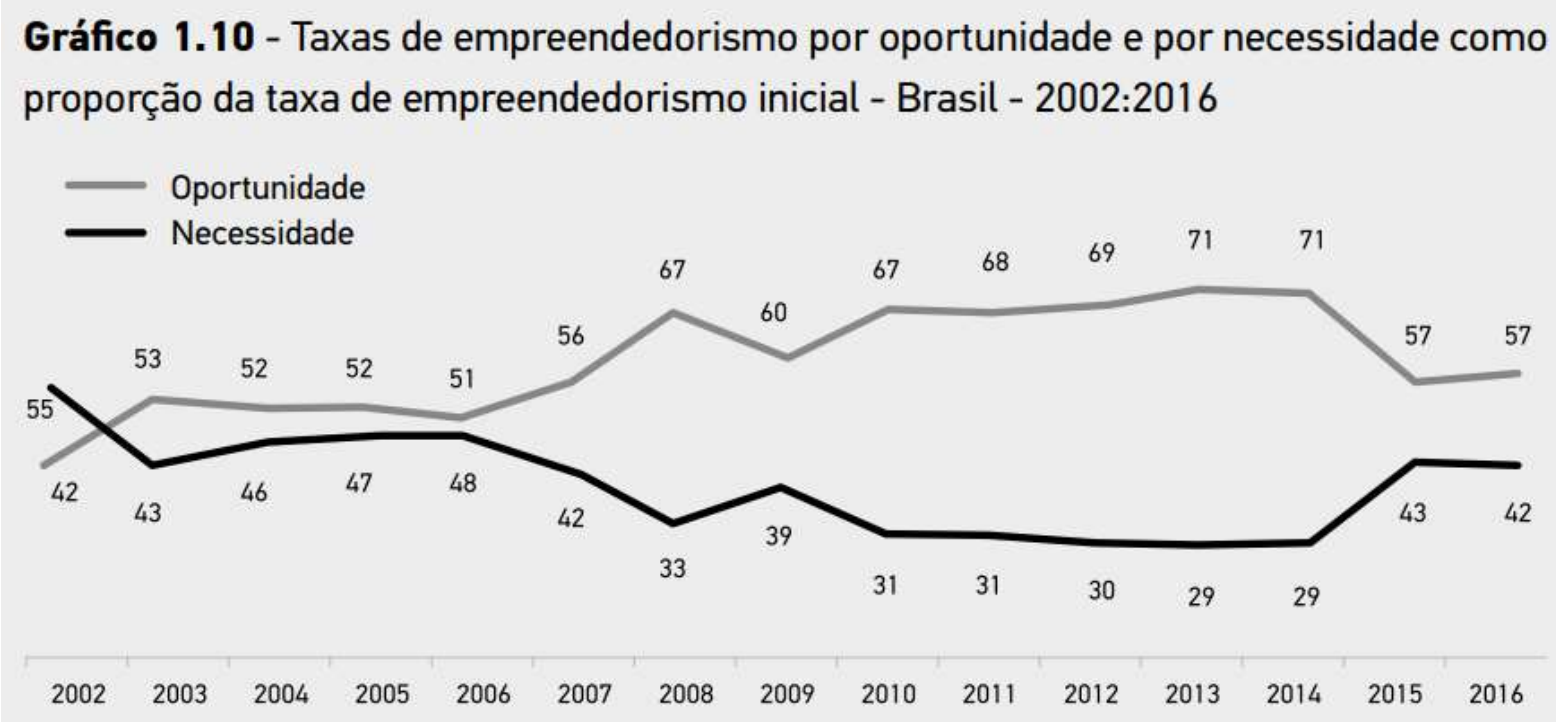

Fonte: GEM, IBGE, Banco do Brasil e Ipeadata

*A soma pode não totalizar $100 \%$ pelo fato de que alguns empreendimentos não é possivel distiguir se é por oportunidade ou necessidade.

Fonte: GEM (2016).

\subsubsection{O empreendedor no centro das discussões}

São muitas as variáveis e condições que podem influenciar no sucesso (ou fracasso) de um empreendimento. O foco desse estudo está na questão comportamental, ou seja, dos comportamentos que os empreendedores praticam que podem leva-los a resultados positivos em seus empreendimentos. O empreendedor tem, portanto, um papel fundamental nesse processo.

E este papel está provavelmente relacionado a um conceito relevante na questão do empreendedorismo, que é o lócus de controle. A definição de lócus de controle foi concebida por Julian Rotter (1966):

[...] um evento observado por alguns como recompensa ou reforço pode ser percebido de forma diferente por outros. Um dos determinantes desta reação é o grau pelo qual o indivíduo percebe que a recompensa ocorre em função do seu próprio comportamento e atributos, versus o grau em ele percebe que a recompensa é 
controlada por forças externas a ele, e pode ocorrer independentemente de suas ações (ROTTER, 1966, p. 1, tradução pelo autor).

Rotter (1966) definiu que quando um reforço não era percebido por indivíduo como sendo consequência de suas ações, e sim de sorte, acaso, destino ou terceiros poderosos, o lócus de controle era externo. Quando o indivíduo percebia que este reforço vinha de seu comportamento e características, o lócus de controle era interno.

Trata-se, dessa forma, de um construto importante para avaliar o empreendedor no papel central da história de sucesso (ou fracasso) de seu empreendimento.

Alguns trabalhos mostram uma correlação importante entre lócus de controle e resultados.

Em sua dissertação de Mestrado, sobre lócus de controle, Flanagan (2014) conclui que "as evidências coletadas suportam as respostas aos questionários, mostrando que os empreendedores acreditavam no controle do seu próprio futuro e destino, através de trabalho árduo e ações. Sorte não fazia parte deste processo" (FLANAGAN, 2014, p. 60, tradução nossa).

Ao analisar o efeito do lócus de controle sobre os comportamentos dos empreendedores, Maciel e Camargo (2010) observaram que:” Verifica-se que um lócus interno de controle conduz a comportamentos empreendedores e, dessa forma, parece potencializar os efeitos desse comportamento sobre o desempenho" (MACIEL; CAMARGO, 2010, p. 184).

Num trabalho que investigou a correlação entre lócus de controle e empreendedorismo na Rússia, utilizando a escala IPC de Levenson (1972), Kaufmann et al. (1995) concluíram que

\footnotetext{
Como sugerido na hipótese 1, empreendedores russos têm lócus de controle interno, e essa percepção de controle interno se sobressaiu em relação à influência de terceiros poderosos. Isto, portanto, dá suporte à noção que percepções de autossuficiência deve ser condição necessária, senão suficiente, para a atividade empreendedora (KAUFMANN et al., 1995, p. 8, tradução nossa).
}

Isto indica, portanto, tratar-se de questões comportamentais, ou seja, de comportamentos que conduzem, através de sua prática, o empreendedor que os pratica a alcançar resultados. Analisar e avaliar como os comportamentos dos empreendedores podem auxiliá-los no caminho para resultados torna-se fundamental para apoiar e incentivar o empreendedorismo. Vale (2014) 
considera que "o conceito de empreender é central para ideologias de diferentes sociedades ao redor do mundo".

Diversos autores se debruçam sobre esse tema, mas um deles, David McClelland, se destacou, como será apresentado com maiores detalhes no Capítulo 2.

A partir de pesquisas realizadas, McClelland (1958) desenvolveu um treinamento de natureza comportamental, denominado TMR, Treinamento de Motivação para a Realização. Ao estudar nove edições do TMR, organizadas em cinco países, Miron e McClelland (1979) concluíram que "o treinamento resultou em significativas melhorias em volume de vendas, em lucratividade, e outras áreas” (MIRON; McCLELLAND, 1979, p. 9, tradução nossa).

Tais resultados chamaram a atenção da USAID - Agência dos Estados Unidos para o Desenvolvimento Internacional, que decidiu contratar uma empresa de consultoria para aprofundar esses estudos. A empresa que venceu a concorrência foi a consultoria MSI, Management Systems International, de Washington, DC (EUA), contratada para desenvolver e realizar "um estudo intercultural que duraria cinco anos" (ALVIM, 2008, p. 77).

A MSI decidiu transformar esse estudo em um projeto conjunto entre a própria MSI e a McBer\&Co, empresa de consultoria que tinha entre seus sócios o próprio David McClelland.

Sandro Morales (2004) apresenta, em sua tese de Doutorado, detalhes importantes sobre este projeto:

\footnotetext{
Em 1983, a Agência Internacional para o Desenvolvimento (USAID) financiou o estudo intercultural para identificar "características empreendedoras pessoais", ou seja, competências capazes de prever a criação e sucesso de negócios em diferentes culturas. O objetivo do estudo era multiplicar e estender a aplicação dos últimos estudos sobre motivação por realização usando a metodologia de mensuração de competências desenvolvida por Lyle Spencer e David McClelland (MORALES, 2004, p. 80).
}

Foi feita uma extensa pesquisa, envolvendo empreendedores de mais de 30 países, de culturas diferentes e de realidades econômicas diferentes, “já que uma das críticas realizadas por diversos pesquisadores a alguns estudos realizados sobre características dos empreendedores é a falta de amostras que permitam uma análise intercultural e inter-racial" (MORALES, 2004, p. 80). 
A partir desta pesquisa, foi feito um novo estudo, em apenas três países, a saber, Equador, Malawi e Índia, cada um representando um continente de países, em sua maioria ainda em desenvolvimento, que catalogou características de comportamento empreendedor comum a empreendedores que alcançavam resultados (e que não estavam presentes naqueles que não os atingiam).

Esses comportamentos comuns a empreendedores de sucesso foram analisados, sobreposições foram eliminadas, comportamentos comuns foram agrupados, e, a partir deles, a MSI desenvolveu um treinamento comportamental de mudança no perfil empreendedor dos seus participantes, com o objetivo de fomentar o empreendedorismo.

\subsection{Relato da experiência (EMPRETEC)}

O treinamento desenvolvido pela MSI é conhecido como EMPRETEC. Esse programa nasceu das pesquisas realizadas pelas empresas MSI e McBer\&Co. Inicialmente, seu nome era “Treinamento de Mudança Comportamental Autodirigida", e, em sua aplicação piloto voltada para empreendedores de área de tecnologia da informação, acabou ganhando o nome de EMPRETEC, que persiste até hoje.

Desde seu início, em 1988, já passaram pelo programa mais de 340 mil empreendedores, em 36 países, em sua maioria em desenvolvimento, que conduzem o programa através de parceiros locais, que por sua vez recorrem a quase 500 facilitadores credenciados (EMPRETEC, 2016).

O Brasil é o país que mais o aplica, através do SEBRAE, a única instituição brasileira com autorização para aplicá-lo, tendo formado desde a década de 90 aproximadamente 250 mil participantes, quase $60 \%$ do total de participantes do programa em todo o mundo.

De acordo com o relatório anual de 2014 (EMPRETEC, 2014), este programa é o grande ícone no processo de geração de capacidade da Conferência das Nações Unidas em Comércio e Desenvolvimento (UNCTAD, na sigla em inglês) e tem como objetivo promover o empreendedorismo e aumentar a capacidade produtiva e competitividade internacional de pequenas e médias empresas (PMEs) em países em desenvolvimento e economias em transição. 
No EMPRETEC (SEBRAE, 2010), em um programa de 6 dias (60 horas), os participantes devem reconhecer (em si e nos outros) e praticar os 30 comportamentos empreendedores identificados na pesquisa, divididos em 10 Características de Comportamento Empreendedor (CCEs) e 3 conjuntos (Planejamento, Realização e Poder), apresentados no quadro a seguir:

Quadro 2 - Características de Comportamento Empreendedor

\begin{tabular}{|c|c|c|}
\hline Conjunto & CCE & Comportamento Empreendedor \\
\hline \multirow[t]{9}{*}{ Planejamento } & Estabelecimento de Metas & $\begin{array}{c}\text { Estabelece metas e objetivos que são } \\
\text { desafiantes e que têm significado pessoal }\end{array}$ \\
\hline & & $\begin{array}{c}\text { Tem visão de longo prazo, clara e } \\
\text { específica }\end{array}$ \\
\hline & & $\begin{array}{c}\text { Estabelece objetivos de curto prazo, } \\
\text { mensuráveis }\end{array}$ \\
\hline & $\begin{array}{c}\text { Planejamento e Monitoramento } \\
\text { sistemático }\end{array}$ & $\begin{array}{l}\text { Divide tarefas de grande porte em } \\
\text { subtarefas com prazos definidos }\end{array}$ \\
\hline & & $\begin{array}{l}\text { Constantemente revisa seus planos } \\
\text { levando em conta os resultados obtidos e } \\
\text { mudanças circunstanciais }\end{array}$ \\
\hline & & $\begin{array}{l}\text { Mantém registros financeiros e utiliza-os } \\
\text { para tomar decisões }\end{array}$ \\
\hline & Busca de Informações & $\begin{array}{l}\text { Dedica-se pessoalmente a obter } \\
\text { informações de clientes, fornecedores ou } \\
\text { concorrentes }\end{array}$ \\
\hline & & $\begin{array}{c}\text { Investiga pessoalmente como fabricar um } \\
\text { produto ou fornecer um serviço }\end{array}$ \\
\hline & & $\begin{array}{l}\text { Consulta especialistas para obter } \\
\text { assistência técnica ou comercial }\end{array}$ \\
\hline \multirow[t]{8}{*}{ Realização } & $\begin{array}{c}\text { Busca de Oportunidades e } \\
\text { Iniciativa }\end{array}$ & $\begin{array}{l}\text { Faz as coisas antes de solicitado ou antes } \\
\text { de forçado pelas circunstâncias }\end{array}$ \\
\hline & & $\begin{array}{l}\text { Age para expandir o negócio a novas } \\
\text { áreas, produtos ou serviços }\end{array}$ \\
\hline & & $\begin{array}{l}\text { Aproveita oportunidades fora do comum } \\
\text { para começar um negócio, obter } \\
\text { financiamento, equipamentos, local de } \\
\text { trabalho ou assistência }\end{array}$ \\
\hline & Correr Riscos Calculados & $\begin{array}{l}\text { Avalia alternativas e calcula riscos } \\
\text { deliberadamente }\end{array}$ \\
\hline & & $\begin{array}{l}\text { Age para reduzir os riscos e controlar os } \\
\text { resultados }\end{array}$ \\
\hline & & $\begin{array}{c}\text { Coloca-se em situações que implicam } \\
\text { desafios ou riscos moderados }\end{array}$ \\
\hline & $\begin{array}{c}\text { Exigência de Qualidade e } \\
\text { Eficiência }\end{array}$ & $\begin{array}{l}\text { Encontra maneiras de fazer as coisas } \\
\text { melhor, mais rápido ou mais barato }\end{array}$ \\
\hline & & $\begin{array}{l}\text { Age de maneira a fazer coisas que } \\
\text { satisfaçam ou excedam padrões de } \\
\text { excelência }\end{array}$ \\
\hline
\end{tabular}




\begin{tabular}{|c|c|c|}
\hline & & $\begin{array}{l}\text { Desenvolve ou utiliza procedimentos para } \\
\text { assegurar que o trabalho seja terminado a } \\
\text { tempo ou que atenda a padrões de } \\
\text { qualidade previamente combinados }\end{array}$ \\
\hline & Persistência & Age diante de um obstáculo significativo \\
\hline & & $\begin{array}{l}\text { Age repetidamente ou muda de estratégia } \\
\text { a fim de enfrentar um desafio ou superar } \\
\text { um obstáculo }\end{array}$ \\
\hline & & $\begin{array}{c}\text { Faz um sacrifício pessoal ou despende um } \\
\text { esforço extraordinário para completar } \\
\text { uma tarefa }\end{array}$ \\
\hline & Comprometimento & $\begin{array}{l}\text { Assume responsabilidade pessoal por } \\
\text { solucionar problemas que possam } \\
\text { prejudicar a conclusão de um trabalho nas } \\
\text { condições estipuladas }\end{array}$ \\
\hline & & $\begin{array}{l}\text { Colabora com seus empregados ou } \\
\text { coloca-se no lugar deles, se necessário, } \\
\text { para terminar uma tarefa }\end{array}$ \\
\hline & & $\begin{array}{l}\text { Esforça-se em manter os clientes } \\
\text { satisfeitos e coloca a boa vontade a longo } \\
\text { prazo acima do lucro a curto prazo }\end{array}$ \\
\hline \multirow[t]{6}{*}{ Poder } & Persuasão e Rede de Contatos & $\begin{array}{l}\text { Utiliza estratégias deliberadas para } \\
\text { influenciar ou persuadir os outros }\end{array}$ \\
\hline & & $\begin{array}{l}\text { Utiliza pessoas-chave como agentes para } \\
\text { atingir seus próprios objetivos }\end{array}$ \\
\hline & & $\begin{array}{l}\text { Age para desenvolver e manter relações } \\
\text { comerciais }\end{array}$ \\
\hline & Independência e Autoconfiança & $\begin{array}{l}\text { Busca autonomia em relação a normas e } \\
\text { controles de outros }\end{array}$ \\
\hline & & $\begin{array}{l}\text { Mantém seu ponto de vista mesmo diante } \\
\text { da oposição ou de resultados inicialmente } \\
\text { desanimadores }\end{array}$ \\
\hline & & $\begin{array}{l}\text { Expressa confiança na sua própria } \\
\text { capacidade de completar uma tarefa difícil } \\
\text { ou de enfrentar um desafio }\end{array}$ \\
\hline
\end{tabular}

Fonte Manual do EMPRETEC (2010).

Os principais objetivos do EMPRETEC são:

- Mostrar a diferença entre operar um negócio (Empresário) e gerir um empreendimento orientado para crescimento e resultados (Empreendedor);

- Promover, entre seus participantes, mudanças comportamentais, através de diversas dinâmicas e exercícios vivenciais, de modo a que essas mudanças levem os participantes a obter melhores resultados em seus empreendimentos.

O Portal do Sebrae (SEBRAE, 2017) apresenta pesquisa com 3.482 clientes que fizeram EMPRETEC. A renda atual/pós-EMPRETEC desse público é maior para $42 \%$ e igual para $51 \%$ 
dos entrevistados. A maior parte das empresas, após a participação no EMPRETEC, registrou um aumento no faturamento mensal. A satisfação geral com o EMPRETEC é muito positiva, com nota média de 9,1 pontos, sendo que $74 \%$ estão muito satisfeitos (atribuíram notas 9 ou 10).

\subsection{Problemática}

O programa EMPRETEC sofreu alterações em seu formato. No início era um programa de duas semanas, em dias úteis, totalizando doze dias. O programa foi então modificado, em função das “dificuldades dos empreendedores se ausentarem por tanto tempo de suas empresas, o SEBRAE [...] implantou a modalidade de 9 dias corridos" (LOPES, 1999, p. 177).

Lopes (1999) ainda destaca que "no programa o participante se envolve e se compromete com as atividades e sua aprendizagem, praticamente trabalha todas as noites, e é muito comum adentrar a madrugada. Portanto é um treinamento que exige tempo e concentração integral dos participantes.” (LOPES, 1999, p. 177). Em função desse grau de exigência e de diversas avaliações feitas pelos próprios participantes, o programa foi novamente modificado, a partir de 2011, passando a ser um programa de 6 dias, sendo esse o formato atualmente vigente.

O autor identificou diversos trabalhos acadêmicos, entre teses de doutorado e dissertações de mestrado sobre o EMPRETEC. Muitos deles são bastante abrangentes, como o de Alvim (2008), que sugere o forte impacto do programa, tanto em profundidade, no curto prazo, quanto em amplitude, no longo prazo, e o de Lopes (1999), que apresentou estudos com participantes antes e depois de sua participação no programa.

Entretanto, esses trabalhos acadêmicos são anteriores à última mudança de formato na duração do programa, ocorrida em 2011, portanto, não refletem efeitos nem consequências desta modificação no efetivo aproveitamento pelo participante.

Embora as estatísticas apresentadas pelo Sebrae em seu portal (SEBRAE, 2017) referentes ao atual formato sejam extremamente positivas, não é possível, a partir delas, avaliar o efetivo grau de aproveitamento da metodologia, já que não são apresentadas estatísticas sobre o grau de aplicação dos comportamentos empreendedores, caráter essencial do programa. 
O autor desta dissertação é empreendedor há mais de 20 anos, tendo participado de diversos empreendimentos, entre os quais importadora e distribuidora de produtos científicos, restaurante, e posto de combustíveis, e participou do programa EMPRETEC em 2011. Atualmente é proprietário de lavanderias, também atua com treinamento empresarial, e é facilitador do programa EMPRETEC, tendo atuado em mais 60 seminários, no Estado de São Paulo, em cidades como Ribeirão Preto, Campinas, São Sebastião, Santo André, São Bernardo do Campo, Osasco, Guarulhos, São José dos Campos, Sorocaba, Franca, e na Capital, nas regiões Oeste, Leste I, Leste II, Norte, Centro, e Sul.

Durante o período de aplicação de seminários EMPRETEC em diferentes cidades do Estado de São Paulo, e diferentes regiões da capital, o autor constatou uma grande heterogeneidade, dentro de uma mesma turma, entre os perfis dos participantes, seu momento empreendedor, suas expectativas em relação ao programa, suas reações ao longo do seminário e outras questões, o que poderia levar a um aproveitamento insatisfatório do programa, prejudicando o desempenho do participante e da turma, pois alguns participantes já teriam seus projetos ou empreendimentos, enquanto outros ainda não tinham certeza sobre o que iriam fazer.

O EMPRETEC, em função de sua metodologia, é um programa que o participante pode fazer apenas uma vez. Portanto, tem que ser aproveitado de maneira muito efetiva pelos seus participantes. Além disso, não existiam, até a elaboração desse projeto, programas similares de complementação ou aprofundamento após a participação no EMPRETEC.

É fundamental, portanto, verificar o retorno que o EMPRETEC traz a seus participantes, de forma a avaliar os efetivos resultados do programa.

\subsection{Problema de pesquisa}

Qual o impacto do EMPRETEC, programa de treinamento em mudança comportamental, no comportamento dos participantes, e nos resultados de seus empreendimentos e projetos?

\subsection{Objetivos da Pesquisa}

1.5.1 Objetivo principal 
- Estudar o impacto do programa EMPRETEC, e sua relação com a prática das 10 características de comportamento empreendedor do programa.

\subsubsection{Objetivos secundários}

- Identificar o momento empreendedor dos participantes (seu projeto empreendedor, sua motivação empreendedora), sua formação, experiência anterior e outras questões;

- Identificar as características de comportamento empreendedor mais praticadas após o programa;

- Verificar a correlação entre a prática das características de comportamento empreendedor, o perfil/momento empreendedor dos participantes, e os resultados alcançados;

- A partir da avaliação dos resultados obtidos, identificar e propor eventuais sugestões na seleção de participantes, na aplicação da metodologia e no formato do programa.

\subsection{Estruturação da Dissertação}

A fim de atingir os objetivos propostos, o autor propõe que o trabalho seja estruturado de acordo com a figura a seguir: 
Figura 1 - Estruturação do projeto

\section{INTRODUÇÃO}

Estudo de impacto de um programa de treinamento comportamental em empreendedorismo - EMPRETEC

Comportamentos empreendedores constituem uma série de ações, atitudes e práticas deliberadas comuns a empreendedores de sucesso, orientados a resultados

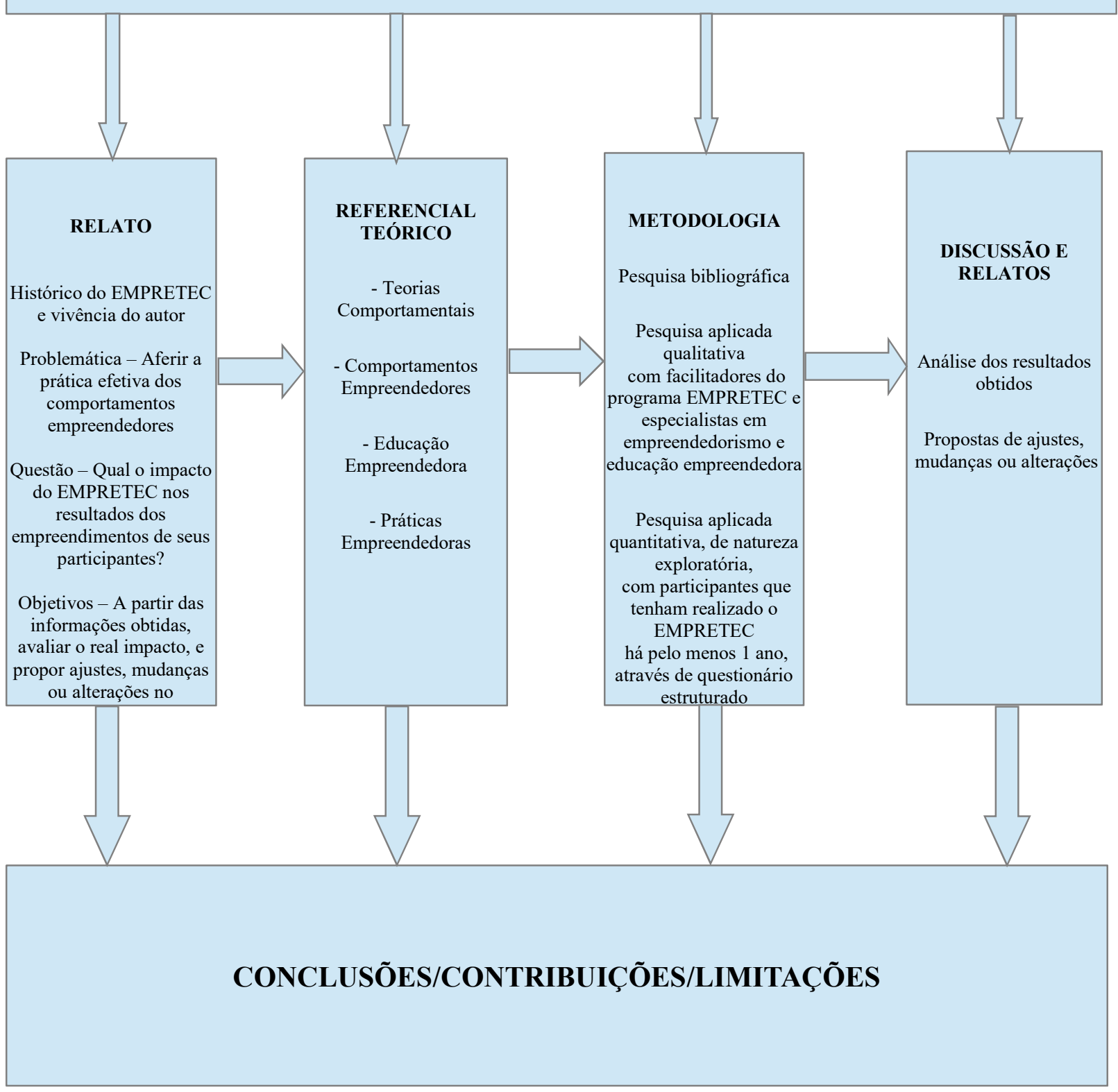

Fonte: Elaborada pelo autor (2017). 
Para executar a estruturação do projeto, a presente dissertação foi dividida em 5 capítulos:

1. O primeiro capítulo apresenta a Introdução ao tema empreendedorismo, sua importância no contexto nacional e mundial, e discorre sobre o relato da experiência, a problemática, e as questões e objetivos que envolvem a dissertação.

2. Referencial teórico - O capítulo 2 traz o referencial teórico utilizado para dar a devida sustentação à dissertação, apresentando a fundamentação que permitiu responder aos diversos questionamentos trazidos à tona no capítulo 1 .

3. Procedimentos metodológicos - Este capítulo apresenta e detalha os procedimentos metodológicos utilizados para obter respostas e tirar conclusões sobre a problemática, e para atender aos objetivos da pesquisa.

4. Análise de dados e resultados - Os dados obtidos através dos procedimentos metodológicos descritos no capítulo anterior são apresentados, sua análise efetuada, e os resultados obtidos são discutidos.

5. Conclusões, limitações e sugestões - Neste último capítulo da dissertação, apresenta-se as conclusões obtidas a partir da análise dos dados e resultados, analisa-se as limitações da pesquisa, com sugestões para estudos futuros que visem compensar as limitações apresentadas. 


\section{REFERENCIAL TEÓRICO}

Programas de Mestrado Profissional trazem à vida acadêmica profissionais com perfis diferentes daqueles normalmente encontrados neste ambiente.

Esta mesma diferença pode ser também percebida nos objetivos das pesquisas normalmente encontradas nesse tipo de programa, e que contemplam dificuldades, desafios e problemas normalmente encontrados na gestão diária de diferentes situações que ocorrem nas empresas e no mercado.

De acordo com Fischer (2005), “a aprendizagem pela experiência, pela prática ou a partir das práticas está no centro das discussões na formação de gestores, entre outros profissionais" (FISCHER, 2005, p. 24).

Um dos inúmeros desafios do Mestrado Profissional é encontrar base teórica sólida e significativa para dar sustentação à análise e proposição de soluções para problemas encontrados na vivência dos Mestrandos que procuram esse tipo de programa.

Francesconi (2016), em sua dissertação de Mestrado, apresenta um conceito importante que contribui para essa fundamentação: "Esta abordagem sistêmica influencia a fundamentação teórica para uma Pesquisa Profissional que tende a buscar conceitos consagrados e ser mais abrangente, a contar pela multidisciplinaridade de áreas da Administração a explorar para dar cobertura ao problema" (FRANCESCONI, 2016, p. 35).

É preciso, dessa forma, mapear as áreas de conhecimento que serão investigadas, fazendo uso, para isso, de uma matriz de amarração, conforme tabela a seguir: 
Tabela 1 - Áreas de conhecimento a serem investigadas

\begin{tabular}{|c|c|c|c|c|}
\hline Modelo teórico & $\begin{array}{l}\text { Objetivos da } \\
\text { pesquisa }\end{array}$ & $\begin{array}{l}\text { Hipóteses a partir } \\
\text { da observação na } \\
\text { prática }\end{array}$ & $\begin{array}{l}\text { Questões da } \\
\text { pesquisa }\end{array}$ & $\begin{array}{l}\text { Técnicas de } \\
\text { análise }\end{array}$ \\
\hline $\begin{array}{l}\text { Teoria } \\
\text { Comportamental em } \\
\text { empreendedorismo }\end{array}$ & $\begin{array}{l}\text { Identificar aspectos } \\
\text { das teorias } \\
\text { comportamentais } \\
\text { aplicadas ao } \\
\text { empreendedorismo }\end{array}$ & $\begin{array}{l}\text { A prática de } \\
\text { comportamentos } \\
\text { empreendedores leva } \\
\text { aqueles que os } \\
\text { aplicam a resultados } \\
\text { melhores e mais } \\
\text { efetivos }\end{array}$ & $\begin{array}{l}\text { Verificar correlação } \\
\text { direta entre prática de } \\
\text { comportamentos } \\
\text { empreendedores e os } \\
\text { resultados alcançados }\end{array}$ & $\begin{array}{l}\text { Pesquisa } \\
\text { bibliográfica }\end{array}$ \\
\hline $\begin{array}{l}\text { Educação } \\
\text { empreendedora }\end{array}$ & $\begin{array}{l}\text { Identificar aspectos } \\
\text { relevantes na forma e } \\
\text { conteúdo de } \\
\text { programas de } \\
\text { educação e } \\
\text { treinamento voltados } \\
\text { a empreendedores }\end{array}$ & $\begin{array}{l}\text { A educação } \\
\text { empreendedora e } \\
\text { voltada para adultos } \\
\text { deve seguir } \\
\text { princípios distintos } \\
\text { da educação } \\
\text { pedagógica, com } \\
\text { aspectos de imediata } \\
\text { aplicação e com base } \\
\text { na andragogia }\end{array}$ & $\begin{array}{l}\text { Identificar programas } \\
\text { de educação } \\
\text { empreendedora, seus } \\
\text { formatos e conteúdos, } \\
\text { e resultados } \\
\text { encontrados }\end{array}$ & $\begin{array}{l}\text { Pesquisa } \\
\text { bibliográfica }\end{array}$ \\
\hline $\begin{array}{l}\text { Impacto da educação } \\
\text { empreendedora no } \\
\text { comportamento } \\
\text { empreendedor }\end{array}$ & $\begin{array}{l}\text { Avaliar o impacto de } \\
\text { programas de } \\
\text { educação } \\
\text { empreendedora nos } \\
\text { resultados dos } \\
\text { participantes }\end{array}$ & $\begin{array}{l}\text { A reação dos } \\
\text { participantes a esses } \\
\text { programas é } \\
\text { extremamente } \\
\text { positiva, mas faltam } \\
\text { dados para apurar sua } \\
\text { real efetividade }\end{array}$ & $\begin{array}{l}\text { Medir o grau de } \\
\text { absorção do que é } \\
\text { apresentado nos } \\
\text { programas, sua } \\
\text { aplicação efetiva, e os } \\
\text { resultados alcançados } \\
\text { após o treinamento }\end{array}$ & $\begin{array}{l}\text { Pesquisa } \\
\text { Bibliográfica } \\
\text { Pesquisa } \\
\text { qualitativa com } \\
\text { facilitadores } \\
\text { experientes do } \\
\text { programa e } \\
\text { profissionais } \\
\text { ligados ao } \\
\text { empreendedorismo } \\
\text { e à educação } \\
\text { empreendedora } \\
\text { Pesquisa } \\
\text { quantitativa com } \\
\text { participantes do } \\
\text { EMPRETEC }\end{array}$ \\
\hline
\end{tabular}

Fonte: Elaborado pelo autor (2017).

Essa matriz permite apresentar, de maneira clara, as devidas amarrações no projeto de pesquisa, e que serão detalhadas no Capítulo 3, de procedimentos metodológicos.

Surgem, dessa matriz, três elementos importantes na fundamentação teórica do projeto:

a) A análise de teorias comportamentais sobre o empreendedorismo, uma vez que a pesquisa está centrada em aspectos dessa natureza, conforme apresentado no Capítulo 1 ; 
b) Aspectos pertinentes à Educação Empreendedora, visto que o problema de pesquisa está baseado no estudo de um programa de treinamento comportamental para empreendedores;

c) A avaliação de impacto em programas de educação empreendedora, ou seja, como estabelecer instrumentos que possam de fato avaliar o resultado desses programas e sua contribuição para os empreendedores.

\subsection{Teorias Comportamentais sobre empreendedorismo}

Aspectos comportamentais relativos ao empreendedorismo têm sido pesquisados, investigados e analisados por diversos autores, em diferentes circunstâncias, com objetivos de pesquisa bastante distintos.

Existem trabalhos que procuraram investigar correlações entre os comportamentos e os tipos psicológicos clássicos, como o de Morales (2004), associando competências e tipos psicológicos junguianos.

Dentro da mesma linha de analisar o empreendedorismo sob a ótica da psicologia, destaca-se o trabalho de Paulino e Rossi (2003), que conseguiram "identificar e relacionar alguns dos pressupostos teóricos tomados como base de estudo sobre a formação do perfil empreendedor" (PAULINO; ROSSI, 2003, p. 205).

Neste trabalho, Paulino e Rossi (2003) procuraram “descrever características e/ou traços de personalidade empreendedora e buscar identificar algumas das condições favoráveis ao seu desenvolvimento" (PAULINO; ROSSI, 2003, p. 205).

Uma das conclusões importantes às quais chegaram é que "As principais críticas decorrem do fato de muitas delas focarem apenas os atributos de personalidade, não se referindo à formação de processos que levam ao entendimento de tais características na formação dos empreendedores" (PAULINO; ROSSI, 2003, p. 210).

Morales (2004), por sua vez, afirma que

A análise estatística dos resultados obtidos mostrou uma baixa correlação entre as competências e os tipos psicológicos de Jung. Isso pode ser interpretado da seguinte 
maneira: é muito mais forte o papel dos "reforçadores" comportamentais citados por McClelland e Rotter no desenvolvimento das "competências empreendedoras" do que de uma "pré-disposição" ao desenvolvimento dessas competências devido ao tipo psicológico (MORALES, 2004, pp.162-163).

Paulino e Rossi destacam também que "o trabalho pioneiro realizado acerca das características comportamentais dos empreendedores foi conduzido pelo Professor da Universidade de Harvard, David McClelland" (PAULINO; ROSSI, 2003, p. 209).

Pioneiro e principal referência em termos de teoria comportamental aplicada ao empreendedorismo, David McClelland (1958) desenvolve diversos trabalhos sobre liderança, conceitualizando uma série de capacidades empreendedoras e atribuindo a essas capacidades a razão do sucesso do empreendedor. É possível perceber, a partir daí, a ênfase na questão comportamental, ou seja, quais são as características comportamentais comuns a empreendedores que atingem resultados.

Num amplo trabalho sobre aspectos motivacionais, David McClelland (1967) aborda três tipos de necessidades que, segundo ele, afetam a motivação humana, a saber: Realização, Afiliação (ou associação) e Poder, apresentadas no quadro a seguir:

Quadro 3 - Bases Motivacionais

\begin{tabular}{|c|c|c|}
\hline Necessidade de Realização & Necessidade de Afiliação & Necessidade de Poder \\
\hline 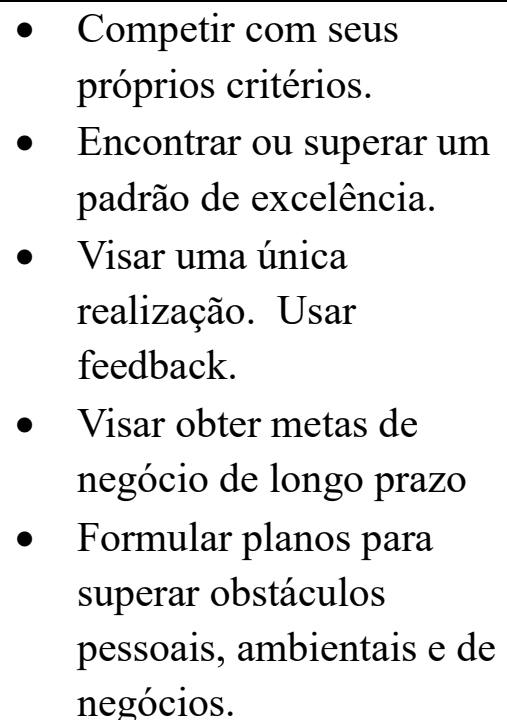 & $\begin{array}{l}\text { - Visar estabelecer laços } \\
\text { de amizade, ser aceito. } \\
\text { - } \text { Procurar fazer parte de } \\
\text { grupos sociais. } \\
\text { - } \text { Sentir grande } \\
\text { preocupação pelo } \\
\text { rompimento de uma } \\
\text { relação interpessoal } \\
\text { positiva. } \\
\text { Possuir uma elevada } \\
\text { preocupação com as } \\
\text { pessoas na sua situação } \\
\text { de trabalho. }\end{array}$ & 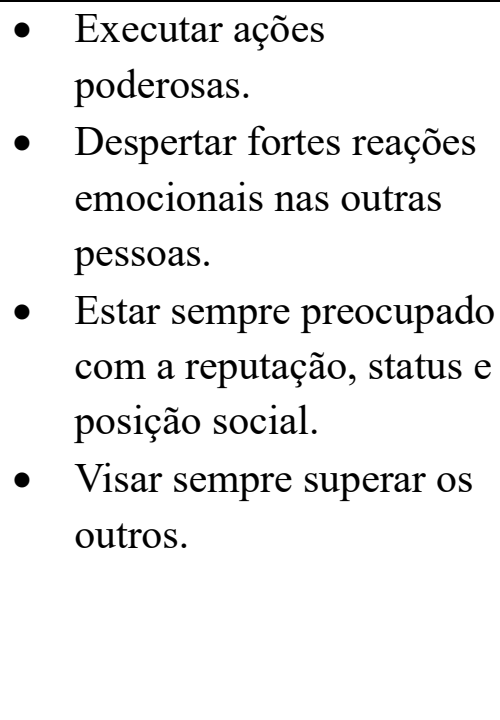 \\
\hline
\end{tabular}

Fonte: PAULINO e ROSSI (2003). 
De acordo com McClelland (1967), pessoas motivadas pela necessidade de realização têm forte tendência a estabelecer e atingir objetivos e metas, a correr riscos calculados para atingi-los, e frequentemente preferem trabalhar sozinhos.

Pessoas motivadas pela necessidade de afiliação (ou associação) querem fazer parte de algum grupo, querem ser apreciadas, favorecem a colaboração em detrimento da competição, e não gostam de riscos ou incerteza elevados.

Já as pessoas motivadas pela necessidade de poder querem controlar ou influenciar os outros, que suas opiniões prevaleçam, são competitivas, e apreciam status e reconhecimento.

Essas necessidades, também conhecidas como bases motivacionais, estão presentes em todos os indivíduos, com predominância de uma delas.

McClelland (1967) concluiu que pessoas com base motivacional de realização, em função de seu perfil, têm melhores chances de alcançar resultados significativos como empreendedores: "uma sociedade que tenha um nível geralmente elevado de realização produzirá um maior número de empresários ativos, os quais, por sua vez, darão origem a um desenvolvimento econômico mais rápido" (MCCLELLAND, 1967, p. 95).

Lenzi et al. (2005) comparam teorias comportamentais distintas, como as de McClelland (1967) e John Miner, que envolvem aspectos distintos de comportamentos empreendedores.

Miner (1998) faz uma análise do empreendedor, considerando que este pode estar enquadrado em quatro estilos ou tipos diferentes. Por meio de pesquisa, ele identificou que cada tipo de empreendedor pode seguir uma carreira profissional específica. Os quatro tipos abordados por Miner são: o realizador, o supervendedor, o autêntico gerente e o gerador de ideias (LENZI et al., 2005, p. 1).

E concluem que:

A relação apresentada no cruzamento de dados entre os dois autores, procurando uma correlação entre ambos, mostra uma significativa surpresa quando se observa um conjunto de características de comportamento empreendedor de McClelland muito semelhante para todos os perfis apresentados por Miner (LENZI et. al, 2005, p. 13).

Como conclusão, podemos perceber a importância dos aspectos comportamentais no sucesso dos empreendimentos, já que eles são os pontos coincidentes entre esses estudos, que envolveram tipos psicológicos, atributos de personalidade, e tipos de inteligência, além da 
comparação dos comportamentos preconizados pelo trabalho iniciado por McClelland com outros tipos de comportamentos, e da percepção da sua prática como determinantes para o sucesso dos empreendimentos.

\subsection{Educação Empreendedora}

As diversas definições de empreendedorismo apresentadas no capítulo 1 indicam diferentes aspectos que envolvem o ato de empreender:

- Assumir riscos;

- Identificar oportunidades;

- Saber planejar;

- Ter criatividade;

- Ter iniciativa;

- Comprometer-se e envolver-se.

A partir daí, é possível perceber que o empreendedorismo é uma área que envolve diversos aspectos, de diferentes disciplinas do conhecimento humano.

A multidisciplinaridade no campo de estudos sobre empreendedorismo é percebida por Vale (2014):

\footnotetext{
Mais de dois séculos separam os cervejeiros mencionados por Adam Smith (1976), em sua obra clássica, dos empreendedores de hoje. Os primeiros viviam em um ambiente socioeconômico caracterizado por uma relativa estabilidade. Eram detentores de ofícios cujas tradições passavam de geração para geração. Os empreendedores atuais, por sua vez, situam-se em um mundo completamente diferente, caracterizado por rápidas transformações e grande competição e são vistos como personagens multifacetados (VALE, 2014, p. 875)
}

Identificar as disciplinas que compõem o amplo espectro do empreendedorismo é parte importante na educação empreendedora. Num extenso trabalho, em que tinham como objetivo indicar a frequência da prática de comportamentos empreendedores no dia a dia dos negócios e predizer os comportamentos mais presentes para o futuro dos empreendimentos, Kyndt e Baert (2015) avaliaram 12 competências empreendedoras em mais de 3000 empreendedores, classificados entre aspirantes, iniciantes e experientes, e demonstraram quais competências empreendedoras predizem o futuro do empreendimento. 
Não só o trabalho de Kyndt e Baert (2015), como o de outros autores importantes, apresentou competências empreendedoras necessárias para o sucesso nos negócios. Mas, essas competências podem ser ensinadas? Ou ainda, podem ser aprendidas? Foi apresentado na introdução que empreendedores natos representam apenas uma pequeníssima parte do universo total do empreendedorismo. Mas, ainda assim, uma questão se fez presente: empreendedores nascem naturalmente, ou podem ser ensinados?

McClelland (1969) afirma, de maneira bastante assertiva, que empreendedores são feitos, ou seja, não nascem como tal, tanto assim que o título de um dos seus trabalhos é "Empreendedores são feitos, não nascem" (Tradução nossa).

A empresa de consultoria Ernst \& Young (2011) publicou um amplo estudo sobre empreendedorismo, que envolveu entrevistas com 685 empreendedores, de mais de 30 países, de 25 diferentes setores da economia, e chegou a diversas conclusões, entre as quais destacase: "Líderes empreendedores são feitos, não nascem" (ERNST; YOUNG, 2011, p. 7), numa afirmação muito similar à de McClelland (1969), feita 42 anos antes.

Percebe-se, a partir daí, uma força empreendedora, que supera "a mera criação de um negócio" (KURATKO, 2003, p. 1, tradução nossa). Pode-se pensar numa perspectiva empreendedora, passível de ser desenvolvida em empreendedores (ou candidatos a). Portanto, "o empreendedorismo é um conceito integrado que permeia em negócios de indivíduos de uma maneira inovadora” (KURATKO, 2003, p. 2, tradução nossa).

Outros autores igualmente estudaram esse tema. Moreira Tavares et al. (2013), através de um trabalho de pesquisa bibliográfica que analisou a importância da educação empreendedora para a formação de novos negócios, concluíram que

\footnotetext{
A formação de empreendedores torna-se um importante fator para o desenvolvimento econômico de uma região, [...] atratora de negócios inovadores e formadora de capital social com elevado nível de conhecimento. A partir dos estudos pesquisados, pode-se perceber a importância da educação empreendedora para a transformação econômica das regiões. A partir destas constatações, observa-se a necessidade das organizações governamentais e das instituições de ensino aterem-se a necessidade de contemplar a educação do empreendedorismo na formação das crianças e jovens, podendo, assim, estabelecer um ambiente propício ao desenvolvimento do empreendedorismo (MOREIRA TAVARES et al., 2013, p. 6).
} 
Num trabalho em que avalia tendências e desafios para a educação empreendedora, Kuratko (2003) é igualmente categórico, ao afirmar que "dada a largamente aceita noção de que empreendimentos são a chave para inovação, produtividade e competição efetiva, a questão de se empreendedorismo pode ou não ser ensinado tornou-se obsoleta" (KURATKO, 2003, p. 12, tradução nossa).

E como acontece o aprendizado dos empreendedores? Ao propor o desenvolvimento de uma estrutura de trabalho conceitual, Politis (2005) busca desvendar, através da revisão e síntese de pesquisas disponíveis, o processo de aprendizagem empreendedora. E identifica nessa estrutura três componentes principais: “A experiência do empreendedor, o processo de transformação, e o conhecimento empreendedor em termos de lidar com a identificação de oportunidades, e com as responsabilidades do novo" (POLITIS, 2005, p. 399, tradução nossa).

A partir dessa estrutura conceitual, Politis (2005) propõe:

a) Quanto mais experiente, mais efetivo é o empreendedor em identificar oportunidades e agir em função delas, e em lidar com as responsabilidades do novo;

b) Que a maneira de se transformar é uma combinação entre sua experiência empreendedora e o conhecimento adquirido;

c) Que os resultados do empreendedor sofrem influência da sua forma de transformar experiência adquirida em conhecimento, bem como fracassos ou sucessos o ajudam a lidar com a busca de oportunidades e com a iniciativa de agir em função delas.

Numa pergunta bastante objetiva, Klein e Bullock (2006) questionam: “O que, então, está sendo ensinado?" (KLEIN; BULLOCK, 2006, p. 3, tradução nossa). E observaram um "divórcio" entre o que os economistas pensam e o que está sendo ensinado como empreendedorismo. Atribuem isso a uma significativa diferença entre pontos de vista dos economistas e suas definições sobre empreendedorismo, versus os educadores que ensinam esse tema nas mais diversas instituições.

Nestas formulações, perguntas sobre o que é um empreendedor, como o empreendedorismo se manifesta na economia ou na sociedade em geral, que técnicas são úteis para treinamento de indivíduos a se tornar empreendedores ou reconhecer quais indivíduos têm talento para empreender, são simplesmente irrelevantes. Daí os principais teóricos econômicos do empreendedorismo oferecerem pouco de valor, além de inspiração e um conjunto de citáveis autoridades científicas, para educadores em empreendedorismo (KLEIN; BULLOCK, 2006, p. 15, tradução nossa). 
E concluem com uma proposta bastante importante para o campo do empreendedorismo: "Nosso desafio é conceitualizar e articular o empreendedorismo como uma forma de pensar, uma abordagem multidisciplinar ao processo de criar valor econômico e social, tendo em consideração a incerteza e os recursos limitados” (KLEIN; BULLOCK, 2006, p. 16, tradução nossa).

Dentro desse desafio proposto por Klein e Bullock (2006), duas questões se destacam: conteúdo e forma, ou seja, o que ensinar aos empreendedores, de modo a capacitá-los a enfrentar os inúmeros desafios que se apresentam em suas jornadas, e como ensinar, de forma que esses ensinamentos tenham de fato impacto positivo nessas jornadas empreendedoras.

Essas questões são igualmente propostas por O'Callaghan (2013): a) o que ensinar aos empreendedores, e b) como ensiná-los. Num programa na Universidade de Nazarbayev, Cazaquistão, foram treinados, somente em 2013, 420 empreendedores, em um programa modular, com duração de 5-6 meses, cujo objetivo principal era destacar capacidades para novos negócios, além de dar suporte e apoio a empreendedores para desenvolver e fazer crescer, de forma sustentável, seus empreendimentos.

Alguns pontos se destacam no trabalho apresentado por O'Callaghan (2013):

a) Um programa efetivo deve mostrar aos alunos "como" se comportar, do ponto de vista empreendedor;

b) A maior parte das escolas de negócio apresentam uma combinação de teoria e prática, frequentemente reforçada pela análise detalhada de problemas comuns aos empreendedores;

c) Pouca atenção é dada aos empreendedores atuais, que já enfrentam os desafios e obstáculos do crescimento e desenvolvimento dos seus empreendimentos;

d) A experiência do estudo realizado indica que a educação empreendedora permite desenvolver uma mudança nas atitudes e comportamentos empreendedores;

e) Para quem participou do programa, novas oportunidades surgiram, recursos foram atraídos, equipes foram treinadas e desenvolvidas;

f) Diferenças foram observadas entre educar empreendedores atuais (versus candidatos a empreendedores): Relevância contextual, feedback que podia ser colocado em prática imediatamente, e rede de relacionamento com seus pares (outros empreendedores em situação semelhante).

De modo a avaliar os progressos feitos em educação empreendedora, Gorman et al. (1997) fizeram um compêndio de artigos publicados sobre educação empreendedora, entre teóricos e empíricos, realizando uma análise histórica de 10 anos. 
Esses artigos foram separados nos seguintes tópicos: propensão ao empreendedorismo, fase pré-empreendimento, empreendimentos em andamento, e estrutura e processo educacional.

Destacam-se alguns pontos nas conclusões obtidas com essa extensa revisão da literatura disponível à época de realização desse estudo:

- A necessidade de distinção entre modelos de educação: “de particular observação é a necessidade de distinguir educação empreendedora, empresarial, e de gestão de pequenas e médias empresas" (GORMAN et al., 1997, p. 3, tradução nossa).

- Em educação empreendedora, deve haver "foco em atributos e habilidades, elementos de experiência concreta, direcionado ao desenvolvimento de negócios, envolvendo a participação prática em projetos e sua consecução" (GORMAN et al., 1997, p. 13, tradução nossa).

- Uma notável ausência de uma abordagem multidisciplinar à educação empreendedora, visto que apenas três dos 29 artigos teóricos pesquisados tratavam de outras áreas do conhecimento além da administração de negócios.

Um importante fator investigado no trabalho de Elmuti et al. (2012), que será visto com maiores detalhes no tópico seguinte, que tratará da avaliação do impacto de programas de treinamento, foi a percepção de empreendedores (tanto aqueles que já empreendem quanto aqueles que querem empreender) em relação à educação empreendedora.

\footnotetext{
Com respeito à educação empreendedora, a maioria, de ambos grupos, expressou apoio a programas que incluam exemplos reais, com o processo de educação empreendedora ocorrendo através da reflexão e interação, ao invés de modelos tradicionais e típicos, que gastam a maior parte do tempo com provas, leituras e pouquíssimas discussões (ELMUTI et al., 2012, p. 94, tradução nossa).
}

Uma segunda, e igualmente importante, conclusão desse trabalho indica que "Primeiro, os resultados atitudinais apresentados nesse estudo indicam que educação empreendedora ainda ofusca outros aspectos que explicam o sucesso ou fracasso de um empreendedor" (ELMUTI et al., 2012, p. 96, tradução nossa).

A importância da educação empreendedora fica evidente diante dos trabalhos analisados, uma vez que empreendedores podem, sim, ser formados, que o processo de educação empreendedora pode melhorar consideravelmente as chances de sucesso dos empreendimentos, em especial 
daqueles que empreendem por necessidade, e ressaltam a importância de aspectos multidisciplinares, atitudinais e comportamentais, e que deve ter um foco especial naqueles que já estão empreendendo.

\subsection{Avaliação de impacto em programas de educação empreendedora}

Alguns dos trabalhos analisados no tópico anterior já deixam claro o impacto de programas de educação empreendedora nos seus participantes, em que se destacam alguns pontos:

- Ter foco em atributos, habilidades e elementos de experiência concreta;

- Permitir desenvolvimento e mudanças em atitudes e comportamentos;

- Propiciar o surgimento de oportunidades, atração de recursos, capacitação de equipes.

O desafio passa a ser, portanto, encontrar formas e critérios para a avaliação do efetivo impacto de programas de treinamento.

Num trabalho bastante amplo de análise do impacto de treinamento como indicador de efetividade, no qual participaram quase três mil funcionários de 7 diferentes organizações, Pilati e Abbad (2005) testaram uma estrutura empírica de instrumento de impacto:

Figura 2 - Estrutura de impacto

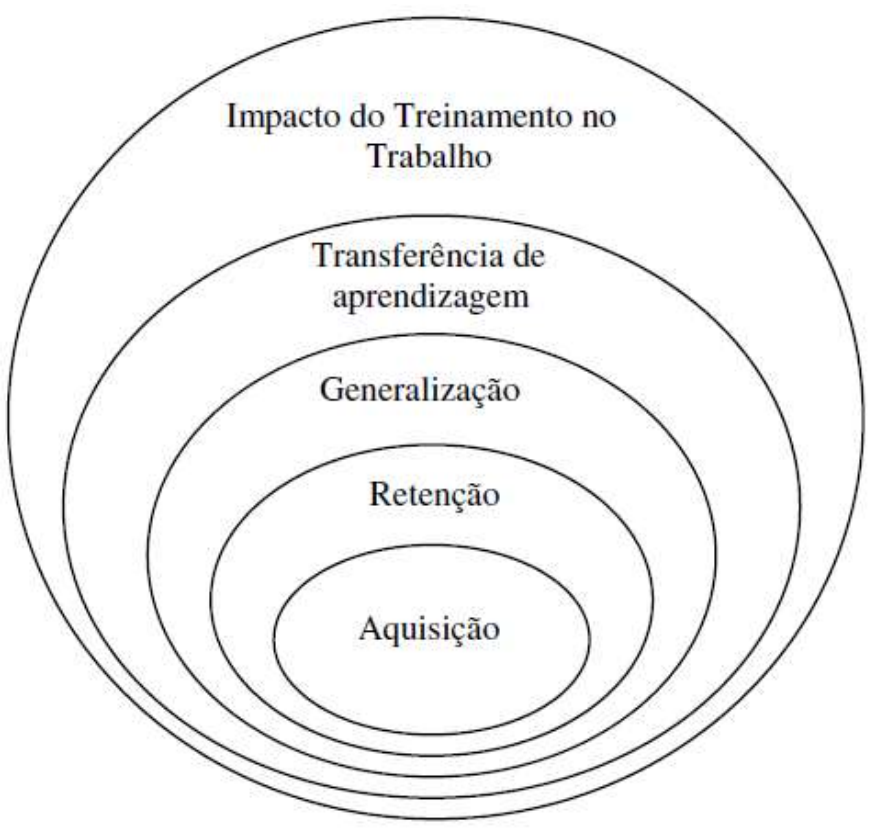


Fonte: PILATI e ABBAD (2005).

Trata-se de um modelo conceitual, desenvolvido por Pilati e Abbad (2005), em que construtos interdependentes são organizados de forma hierárquica:

- Aquisição: Resultado central e imediato no indivíduo - "Aquisição pode ser definida como o processo básico de apreensão de conhecimentos, habilidades e atitudes, desenvolvidos na ação instrucional” (PILATI; ABBAD, 2005, p. 44);

- Retenção: Armazenamento de informações - “esse processo de retenção passaria pelo armazenamento de informações na memória de trabalho ou de curto prazo" (PILATI; ABBAD, 2005, p. 44);

- Generalização: “[...] o grau com que os comportamentos obtidos por meio de treinamentos são exibidos pelo egresso no trabalho e aplicados a situações e condições diferentes daquelas de treinamento" (PILATI; ABBAD, 2005, p. 44);

- Transferência de aprendizagem: Aplicação eficaz dos conhecimentos - "Esse conceito descreve um dos processos centrais de interesse dos modelos de avaliação de treinamento, no nível de comportamento no cargo" (PILATI; ABBAD, 2005, p. 45);

- Impacto do treinamento no trabalho: Influência do treinamento sobre o desempenho global do participante - "fazem parte desse conceito indicadores de mudanças no desempenho global do treinado, bem como em sua motivação e atitudes em relação ao seu trabalho" (PILATI e ABBAD, 2005, p. 45).

Como conclusão desse trabalho, afirmam "que a proposta conceitual de impacto do treinamento no trabalho foi corroborada" (PILATI; ABBAD, 2005, p. 50), e apresentam uma importante colaboração para programas de treinamento:

Dessa forma, torna-se possível o relacionamento entre o resultado do treinamento no trabalho e questões substantivas do desempenho humano, auxiliando na compreensão do comportamento humano no trabalho e a função exercida pelos sistemas organizacionais. Medidas de avaliação de impacto em amplitude são bastante úteis na comparação de efeitos de treinamentos diversos sobre o comportamento dos seus participantes, uma vez que padroniza os indicadores de avaliação, tornando-os genéricos e objetivos (PILATI; ABBAD, 2005, p. 50). 
Dessa importante colaboração, é fundamental ressaltar o relacionamento entre o resultado do treinamento com questões substantivas do comportamento no trabalho e a comparação dos efeitos desses diferentes treinamentos sobre o comportamento.

Em um trabalho com 170 empreendedores, Elmuti et al. (2012) procuraram examinar o impacto de treinamento e educação empreendedora no desenvolvimento e aprimoramento de habilidades empreendedoras necessárias para melhorar a efetividade dos empreendimentos.

Concluíram que "os dados demonstram que educação empreendedora e programas de treinamento parecem criar abertura, confiança e confiabilidade entre os participantes desse estudo" (ELMUTI et al., 2012, p. 83, tradução nossa). Nesse estudo, Elmuti et al. (2012) definiram o que denominaram de variáveis de sucesso:

- Competências empreendedoras, como intuição, extroversão, atitude diante do risco, flexibilidade e senso de independência;

- Habilidades gerenciais, como ter estratégia de nicho, ter um sistema efetivo de orçamento, e uma estrutura organizacional simples.

A pesquisa foi dividida em 4 partes:

a) Motivações e razões para empreender (ou porque haviam empreendido);

b) Fatores percebidos como decisivos para o sucesso ou fracasso do empreendimento;

c) Características demográficas dos entrevistados;

d) Indicadores de desempenho da atividade empreendedora, como performance, adaptabilidade e satisfação.

Com relação a esses indicadores de desempenho, esse estudo demonstrou, através da análise de regressão múltipla, correlação positiva entre educação empreendedora, performance, adaptabilidade e satisfação.

É possível perceber que a última etapa dos construtos verificados por Pilati e Abbad (2005) pôde ser confirmada por Elmuti et al. (2012), ou seja, o impacto do treinamento em educação empreendedora foi positivo no universo estudado por esses autores. 
Visto que os construtos propostos por Pilati e Abbad (2005) foram apresentados em escala hierárquica, pode-se deduzir que os demais construtos, aquisição, retenção, generalização e transferência, também foram atendidos.

Para auxiliar na solidificação desses conceitos, e apresentar alternativas importantes para a análise de impacto de programas de treinamento em educação empreendedora, Brown e Hanlon (2004) desenvolveram uma escala de observação comportamental (Behavioural observation scales, BOS, na sigla, em inglês) para empreendedores.

Escala semelhante fora proposta por Latham e Wexley (1977). Num trabalho que consistia em analisar o desempenho de supervisores em uma indústria madeireira, eles desenvolveram uma escala de observação quantitativa através da avaliação de incidentes críticos. Tal escala se mostrou melhor do que métodos anteriores, que envolviam o enquadramento de determinados comportamentos a partir da observação e julgamento por parte de observadores, essencialmente qualitativos. Eles concluíram que "isto é provavelmente devido ao fato de que uma escala baseada em fatores tornou mais eficiente o uso da informação agrupada em escores compostos, que tinham uma relação mais estável para serem usados como preditores" (LATHAM; WEXLEY, 1977, p. 264, tradução nossa).

Propondo adaptar o trabalho de Latham e Wexley (1977), Brown e Hanlon (2004) trazem, como alegação inicial, um fator extremamente importante para esse campo:

\footnotetext{
Se queremos desenvolver e treinar empreendedores (existentes e potenciais), é importante entender o que os empreendedores fazem que contribui para o seu sucesso final. Consequentemente, é necessário concentrar a nossa atenção não apenas no desempenho de novos empreendimentos, mas também no desempenho dos próprios empreendedores. Compreender os comportamentos subjacentes que diferenciam empreendedores eficazes de ineficazes pode facilitar o desenvolvimento e treinamento de potenciais empreendedores e proporcionar uma base para a melhoria contínua dos empreendedores existentes à medida em que eles desenvolvem e fazem crescer seus empreendimentos. (BROWN; HANLON, 2004, p. 104, tradução nossa).
}

Note-se aí uma preocupação inicial, e muito pertinente, na análise comportamental do empreendedor, como centro de um processo de investigação que pode contribuir para a melhoria contínua dos empreendimentos existentes, e para o desenvolvimento adequado de empreendedores potenciais ou iniciantes. 
Nesse trabalho, envolvendo 34 empreendedores canadenses que haviam recebido prêmio de jovens empreendedores pelo Banco do Canadá, os autores puderam levantar 9 dimensões de comportamentos empreendedores, nas quais classificaram 47 comportamentos.

A escala BOS foi desenvolvida em 7 etapas, de acordo com a tabela a seguir:

Tabela 2 - Etapas de elaboração da Escala BOS

\section{Etapa 1}

Levantamento de incidentes críticos - Nessa etapa, Brown e Hanlon (2004) solicitaram aos respondentes três exemplos de comportamentos, eficazes e ineficazes, por eles observados em terceiros. Foram levantados 104 incidentes eficazes e 91 ineficazes, dos quais $10 \%$ foram separados para validação posterior.

\section{Etapa 2}

Desenvolvimento dos itens comportamentais - Os incidentes críticos foram agrupados em idênticos ou similares, resultando em 47 itens comportamentais observados.

\section{Etapa 3}

Criação da escala comportamental - Os 47 itens comportamentais de etapa anterior foram agora agrupados, por similaridade, em 9 dimensões:

(1) Conhecimento necessário para o negócio escolhido

(2) Identificação de Oportunidades

(3) Dedicação ao negócio

(4) Capacidade de mobilizar recursos e suporte de terceiros

(5) Desenvolvimento estratégico do negócio e crescimento

(6) Habilidades de gestão financeira

(7) Gerenciamento de funcionários

(8) Gerenciamento de relacionamento com clientes e marketing

(9) Outros

\section{Etapa 4}

Validação do conteúdo - Os 10\% dos incidentes críticos separados na etapa 1 foram testados, para verificação de novos itens comportamentais eventualmente não encontrados na etapa 2. Esses incidentes críticos não indicaram novos comportamentos, o que validou os já encontrados.

\section{Etapa 5}


Verificação - Especialistas, que ensinavam empreendedorismo em universidades, foram solicitados a classificar os 47 itens comportamentais dentro das 9 dimensões.

\section{Etapa 6}

Sintonia - Itens que apresentaram índices de correlação abaixo de $80 \%$ na etapa anterior foram reclassificados. Isto aconteceu com 2 itens, e com a nona dimensão, que foi renomeada como "Negociação e riscos".

\section{Etapa 7}

Escala - Uma escala Likert foi adicionada à BOS, de Zero - Quase nunca - a Quatro - Quase sempre.

Fonte: Brown e Hanlon (2004).

Se Gorman et al. (1997) haviam observado "uma notável ausência de uma abordagem multidisciplinar à educação empreendedora" (GORMAN ET AL., 1997, p. 13, tradução nossa), Brown e Hanlon (2004) concluíram que a escala BOS “dá suporte à natureza multidimensional de comportamentos relacionados ao sucesso empreendedor" (BROWN; HANLON, 2004, p. 110, tradução nossa).

E complementam essa análise: "Parece ser provável que muito dessa diversidade deva ser atribuída à complexidade das tarefas empreendedoras" (BROWN; HANLON, 2004, p. 111, tradução nossa).

Uma parte crucial desse estudo é o cruzamento entre aspectos comportamentais e gerenciais, como já percebido por Elmuti et al. (2012). “Os resultados também confirmam a importância de comportamentos gerenciais, como gerenciamento de finanças e marketing, com comportamentos empreendedores, como identificação de oportunidades, e capacidade de mobilizar recursos de terceiros” (BROWN; HANLON, 2004, p. 116, tradução nossa).

Doze anos depois, Brown e Hanlon (2016) voltaram ao tema, apresentando um estudo de validação da escala BOS, através de uma pesquisa com 149 empreendedores canadenses, comparando as 9 dimensões identificadas no estudo de 2004 com 12 índices não comportamentais de desempenho. "Neste artigo, procuramos abordar a falta de desenvolvimento sistemático e estruturas validadas disponíveis aos programas de educação empreendedora" (BROWN; HANLON, 2016, p. 399, tradução nossa). 
A escala BOS, desenvolvida por eles mesmos em 2004, foi considerada adequada para esse estudo, já que o critério que serviu de base foi a análise de incidentes críticos. "O método de incidente crítico é considerado saudável, e poucas modificações têm foi proposto nos últimos 50 anos" (BROWN; HANLON, 2016, p. 403, tradução nossa).

Tabela 3 - Escala BOS

\begin{tabular}{|c|c|}
\hline Dimensão & Comportamento \\
\hline $\begin{array}{lllll}\text { Conhecimento relevante } & \text { para } & \text { o negócio } \\
\text { escolhido } & & & & \end{array}$ & $\begin{array}{l}\text { - Tem educação relevante para o negócio } \\
\text { escolhido } \\
\text { - Tem conhecimento necessário da indústria } \\
\text { antes de começar o negócio } \\
\text { - Possui conhecimento geral de negócios }\end{array}$ \\
\hline Identificação de oportunidades & $\begin{array}{l}\text { - Realiza pesquisas de mercado adequadas antes } \\
\text { de iniciar um negócio } \\
\text { - Identifica um nicho de mercado adequado que } \\
\text { pode sustentar o negócio } \\
\text { - Desenvolve produtos/serviços para } \\
\text { corresponder às necessidades do mercado }\end{array}$ \\
\hline Dedicação ao negócio & $\begin{array}{l}\text { - Dedica longas horas para o negócio } \\
\text { - Está fisicamente presente e assume a } \\
\text { responsabilidade pela gestão do dia a dia do } \\
\text { negócio } \\
\text { - Demonstra uma convicção de que o negócio } \\
\text { dará certo } \\
\text { - Persevera, apesar de contratempos de negócios } \\
\text { - Motiva a si mesmo } \\
\text { - Faz o que for preciso para realizar o trabalho }\end{array}$ \\
\hline $\begin{array}{l}\text { Capacidade de mobilizar suporte e recursos de } \\
\text { terceiros }\end{array}$ & $\begin{array}{l}\text { - É honesto em lidar com os principais } \\
\text { intervenientes } \\
\text { - Estabelece credibilidade no início do negócio - } \\
\text { Adquire capital suficiente antes do start-up de } \\
\text { negócios } \\
\text { - Recebe conselhos de outros } \\
\text { - Pede aconselhamento de especialistas } \\
\text { - Contrata pessoas com as competências } \\
\text { necessárias para o o negócio } \\
\text { - Cobre suas fraquezas contratando pessoas com } \\
\text { habilidades complementares } \\
\text { - Constrói relacionamentos para facilitar o risco } \\
\text { de negócio } \\
\text { - Adquire o equipamento necessário para } \\
\text { produzir um produto/serviço de qualidade }\end{array}$ \\
\hline $\begin{array}{l}\text { Desenvolvimento estratégico do negócio e } \\
\text { crescimento }\end{array}$ & $\begin{array}{l}\text { - Começa pequeno e gradualmente cresce o } \\
\text { negócio } \\
\text { - Expande o negócio, identificando novos } \\
\text { mercados para produtos/serviços } \\
\text { - Estabelece metas para o negócio } \\
\text { - Evita dependência de um ou dois clientes }\end{array}$ \\
\hline
\end{tabular}




\begin{tabular}{|c|c|}
\hline & $\begin{array}{l}\text { - Mantém o controle de tomada de decisão do } \\
\text { negócio } \\
\text { - Tem uma visão clara de onde o negócio está } \\
\text { indo } \\
\text { - Continua focado no core business } \\
\text { - Mantém focado em prioridades empresariais- } \\
\text { chave } \\
\text { - Prontamente se adapta à mudança de ambiente }\end{array}$ \\
\hline Habilidades de gestão financeira & $\begin{array}{l}\text { - Demonstra as habilidades financeiras } \\
\text { necessárias para efetivamente executar o } \\
\text { negócio - Regularmente mantém o controle da } \\
\text { posição financeira do negócio } \\
\text { - Mantém baixos níveis de custos fixos } \\
\text { - Não gasta quantias excessivas com itens de } \\
\text { luxo ou itens pessoais } \\
\text { - Mantém um nível de endividamento que o } \\
\text { negócio pode sustentar }\end{array}$ \\
\hline Gestão de equipes & $\begin{array}{l}\text { - Trata os funcionários de forma justa } \\
\text { - Comunica-se regularmente com os } \\
\text { funcionários }\end{array}$ \\
\hline $\begin{array}{l}\text { Gestão de relacionamento com clientes e } \\
\text { marketing }\end{array}$ & $\begin{array}{l}\text { - Constrói relações eficazes com os clientes } \\
\text { - Vende produtos/serviços de forma pró-ativa e } \\
\text { agressiva } \\
\text { - Atende às expectativas do cliente } \\
\text { - Oferece serviço exemplar, excedendo as } \\
\text { expectativas dos clientes } \\
\text { - Garante um produto de alta qualidade/serviço } \\
\text { - Adapta serviços/ produtos para atender às } \\
\text { necessidades do mercado } \\
\text { - Anuncia e promove produtos/serviços } \\
\text { - Desenvolve um plano de marketing eficaz }\end{array}$ \\
\hline Negociação e riscos & $\begin{array}{l}\text { - Tem capacidade de fechar negociações } \\
\text { - Toma riscos calculados quando a oportunidade } \\
\text { apropriada de negócio surge }\end{array}$ \\
\hline
\end{tabular}

Fonte: Brown e Hanlon (2016, tradução nossa).

As 9 dimensões levantadas por Brown e Hanlon (2004) foram comparadas com 12 indicadores de desempenho. Esses indicadores foram divididos em 4 categorias, conforme mostra a tabela a seguir:

Tabela 4 - Indicadores de desempenho

\begin{tabular}{l|l}
\hline Categoria & Indicador de desempenho \\
\hline Sucesso inicial & Número de funcionários no primeiro ano \\
\hline & Vendas no primeiro ano \\
\hline Desempenho financeiro & Crescimento no número de funcionários \\
\hline & Crescimento de vendas objetivas \\
\hline & Crescimento de vendas subjetivas \\
\hline
\end{tabular}




\begin{tabular}{l|l}
\hline & Lucro \\
\hline & Fluxo de caixa \\
\hline Desempenho operacional & Geração de resultados para os sócios \\
\hline & Qualidade de serviço/produto \\
\hline & Satisfação dos funcionários \\
\hline Índice ponderado & Satisfação dos clientes \\
\hline
\end{tabular}

Fonte: Brown e Hanlon (2016, tradução nossa).

Desses 12 indicadores, 4 foram classificados como objetivos pelos pesquisadores: a) número de funcionários ao final do primeiro ano de operação, b) crescimento do número de funcionários, c) vendas no primeiro ano de operação, e d) crescimento de vendas. Os demais foram considerados como indicadores subjetivos.

Brown e Hanlon (2016) relatam que "indicadores subjetivos abordam a satisfação dos respondentes com esses índices, já que o contentamento com o desempenho mostra ter alta percentagem de divulgação, forte consistência interna, e confiabilidade relativamente alta" (BROWN; HANLON, 2016, p. 407, tradução nossa).

De acordo com esse estudo, "Todas as 9 dimensões bem como as pontuações totais na escala BOS se correlacionaram significativamente com a maior parte dos 12 indicadores de desempenho" (BROWN; HANLON, 2016, p. 399, tradução nossa).

Na média, cada dimensão se correlacionou com 7,2 indicadores de desempenho; seis das nove dimensões se correlacionaram em cada uma das quatro categorias dos indicadores de desempenho, e o total da escala BOS se correlacionou com 11 dos 12 indicadores de desempenho.

Em sua dissertação de Mestrado, Reis (2013), centrada no “objetivo principal de identificar as influências da capacitação em comportamentos empreendedores na gestão de pequenas empresas" (REIS, 2013, p. 7), também estabelece a comparação entre a prática de comportamentos empreendedores e resultados, de acordo com o Modelo de Excelência da Gestão (MEG), preconizado pela Fundação Nacional para a Qualidade (FNQ). 
Numa pesquisa em que entrevistou 170 empresários, Reis (2013) correlacionou a prática de comportamentos empreendedores, avaliada segundo as dez CCEs do EMPRETEC, critérios e práticas de gestão, com resultados organizacionais, de acordo com o MEG.

De acordo com Reis (2013), há uma integração de critérios para um modelo de excelência:

\begin{abstract}
A sobrevivência e o sucesso de uma empresa estão diretamente relacionados à sua capacidade de atender às necessidades e às expectativas dos CLIENTES e à atuação de forma responsável na SOCIEDADE e nas comunidades com as quais interage. De posse dessas informações, a LIDERANÇA formula as ESTRATÉGIAS e estabelece os PLANOS de ação e metas para conquistar os resultados desejados. Os planos e as metas são comunicados aos colaboradores e acompanhados. As PESSOAS (colaboradores que trabalham na empresa) devem estar capacitadas e atuando em um ambiente adequado para que os PROCESSOS sejam executados conforme o planejado, com o controle de custos, investimentos e riscos. É importante, ainda, aperfeiçoar o relacionamento com os fornecedores, a fim de que as necessidades dos clientes sejam entendidas por aqueles que fornecerão os insumos necessários para a execução dos processos. Na empresa, de acordo com o MEG, são realizados procedimentos para conferir e controlar o que está sendo colocado em prática. Para efetivar a etapa do Controle, são medidos os RESULTADOS em relação à situação econômico-financeira, clientes e mercado, pessoas, sociedade, processos principais do negócio e processos de apoio e fornecedores. Esses resultados, em forma de INFORMAÇÕES E CONHECIMENTO, retornam a toda a empresa, para que esta aprenda com os acertos e erros cometidos, e inicie novamente o planejamento, recomeçando o ciclo (REIS, 2013, p. 36).
\end{abstract}

Como resultados mais importantes, Reis (2013) destaca:

1) Que os empretecos ${ }^{2}$ apresentaram maiores percentuais nas práticas de gestão;

2) Que dos 8 critérios de gestão avaliados, 5 são mais praticadas pelo grupo de empretecos;

3) O critério resultados, crucial para competitividade empresarial, tem práticas com índices superiores, no grupo de empretecos;

4) A perfeita correlação entre comportamento e práticas de gestão;

5) Ancorando-se na análise discriminante que demonstra a diferenciação entre os grupos e assim confirma o diferencial de ter participado da capacitação em comportamentos empreendedores (REIS, 2013, p. 62).

A partir dos estudos apresentados, é possível concluir que há formas, sejam elas quantitativas ou qualitativas, de se avaliar o impacto de programas de treinamento, em particular de educação empreendedora, que é o objetivo principal desse estudo.

\footnotetext{
${ }^{2}$ São comumente chamados de empretecos aqueles que participaram do EMPRETEC.
} 


\section{PROCEDIMENTOS METODOLÓGICOS}

A pesquisa em um trabalho acadêmico pode ser considerada como a base, a fundação para a obtenção de resultados consistentes, que possam ajudar na explicação de determinados fenômenos.

De acordo com Silva e Menezes (2005), "Pesquisar significa, de forma bem simples, procurar respostas para indagações propostas" (SILVA; MENEZES, 2005, p. 19).

O presente trabalho está sendo apresentado dentro do âmbito de um programa de Mestrado Profissional. Krakauer et al. (2015) destacam que "trata-se de uma modalidade de PósGraduação stricto sensu voltada para a capacitação de profissionais, nas diversas áreas do conhecimento, mediante o estudo de técnicas, processos, ou temáticas que atendam a uma demanda no mercado de trabalho" (KRAKAUER et al., 2015, p. 2). Outro aspecto importante em programas de Mestrado, sejam eles Acadêmicos ou Profissionais, está na geração de conhecimento relevante, e confiável. Desta forma, podemos considerar a pesquisa como um conjunto de ações e proposições que auxiliem na obtenção, através de uma base sólida, de fundamentação teórica para problemas encontrados no dia a dia da administração, em particular dos micro, pequenos e médios empreendimentos objetos desse estudo.

Isso se reflete diretamente nos temas pesquisados, nos procedimentos utilizados e, principalmente, nas prioridades desses programas.

Ribeiro (2007) descreve as prioridades do Mestrado Profissional:

Em princípio, são dois os eixos de prioridades nos mestrados profissionais. O primeiro é o que agrega competitividade e produtividade a nossas empresas, públicas ou privadas. Inserem-se aqui muitos MPs oferecidos nas engenharias e na administração. Segundo é o que melhora a gestão dos setores sociais do governo e, porque não, de ONGs e de outras organizações de espírito público, ainda que não estatais (RIBEIRO, 2007, p. 2).

Há, dessa forma, a ênfase na existência de um problema prático para o qual se quer encontrar soluções consistentes, com forte embasamento teórico. Como destaca Fischer (2005), "Deve conter a descrição e discussão dos resultados, conclusões e recomendações de aplicações práticas e serem ancoradas em um referencial teórico" (FISCHER, 2005, p. 28). 
Portanto, o objetivo principal de uma pesquisa realizada no âmbito do Mestrado Profissional é o da aplicação prática. Silva e Menezes (2005) classificam a natureza deste tipo de pesquisa como aplicada, já que "objetiva gerar conhecimentos para aplicação prática e dirigidos à solução de problemas específicos. Envolve verdades e interesses locais" (SILVA; MENEZES, 2005, p. 20).

O que se deseja, nessa abordagem, é a propositura de sugestões que possam, se for o caso, contribuir para uma maior eficiência da realidade existente, ou mesmo mudá-la, se necessário.

Destaca-se a contribuição de Krakauer et al. (2015) ao proporem um ciclo para a elaboração de pesquisas, no âmbito do Mestrado Profissional em Empreendedorismo da FEA-USP, para o qual esse trabalho está sendo submetido:

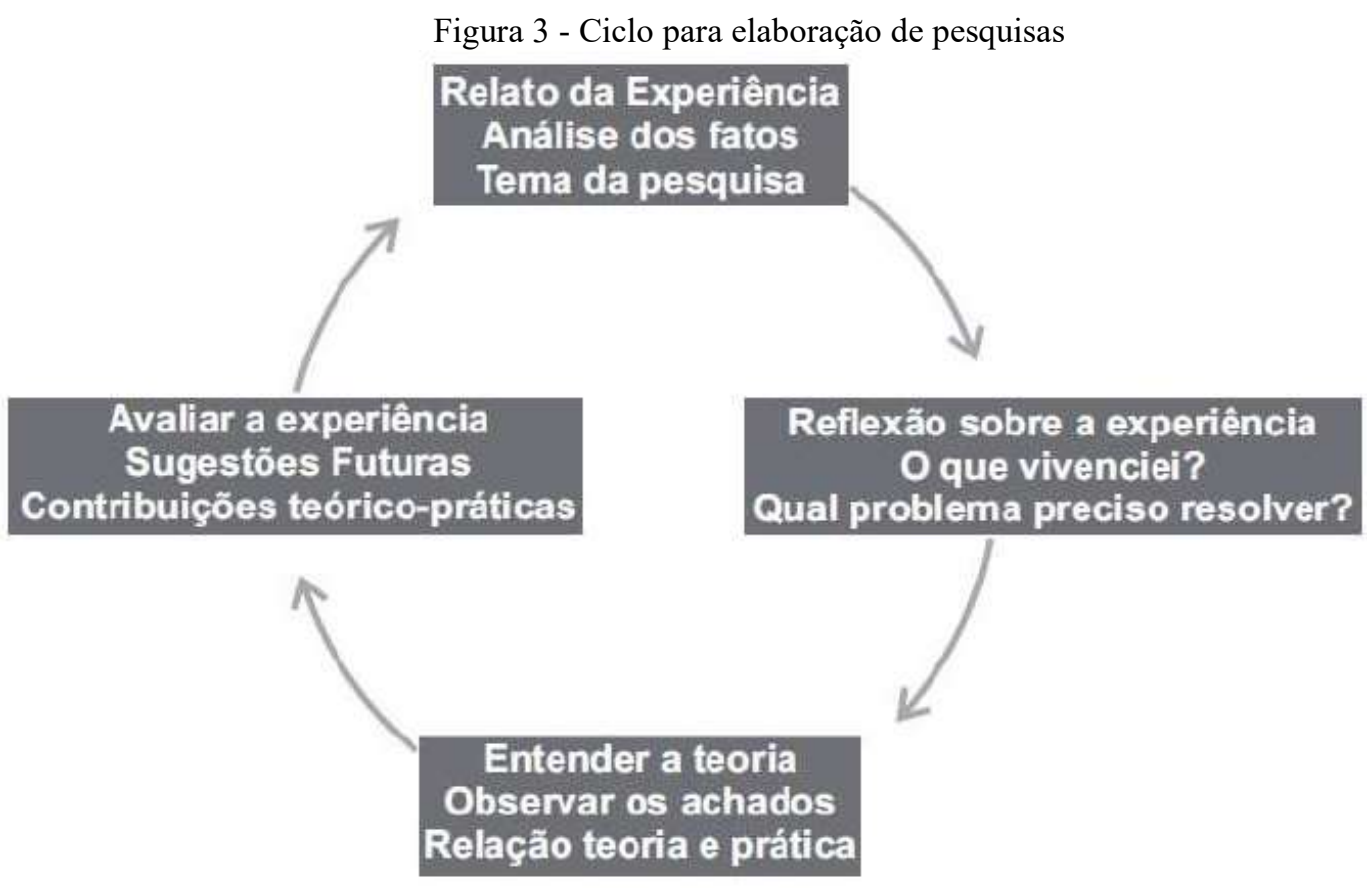

Fonte: Krakauer et al. (2015).

Como destaca Francesconi (2016),

A teoria remete a um ciclo que parte da experiência concreta, representando o fazer, passa pela observação reflexiva, momento de pensar sobre a experiência, chega à conceitualização abstrata, quando o pesquisador passa a entender as teorias ligadas à sua prática e culmina na experimentação ativa (FRANCESCONI, 2016, p. 71). 
Nesse sentido, pode-se entender esse processo como parte de um ciclo de aprendizagem, ainda mais amplo que o proposto por Krakauer et al. (2015), em que as diferentes experiências sobre um determinado tema possam, em conjunto com a base teórica, rever soluções adotadas, propor modificações e analisar os seus impactos. É importante destacar que esse ciclo não será completo, na medida em que o escopo do trabalho alcança a propositura de eventuais modificações, mas não poderá sua eventual implantação, nem mesmo os efeitos dessa.

Pode-se definir esse trabalho de pesquisa na forma do seguinte fluxo:

Figura 4 - Fluxo do trabalho de pesquisa

Identificação e contextualização do problema encontrado na prática profissional

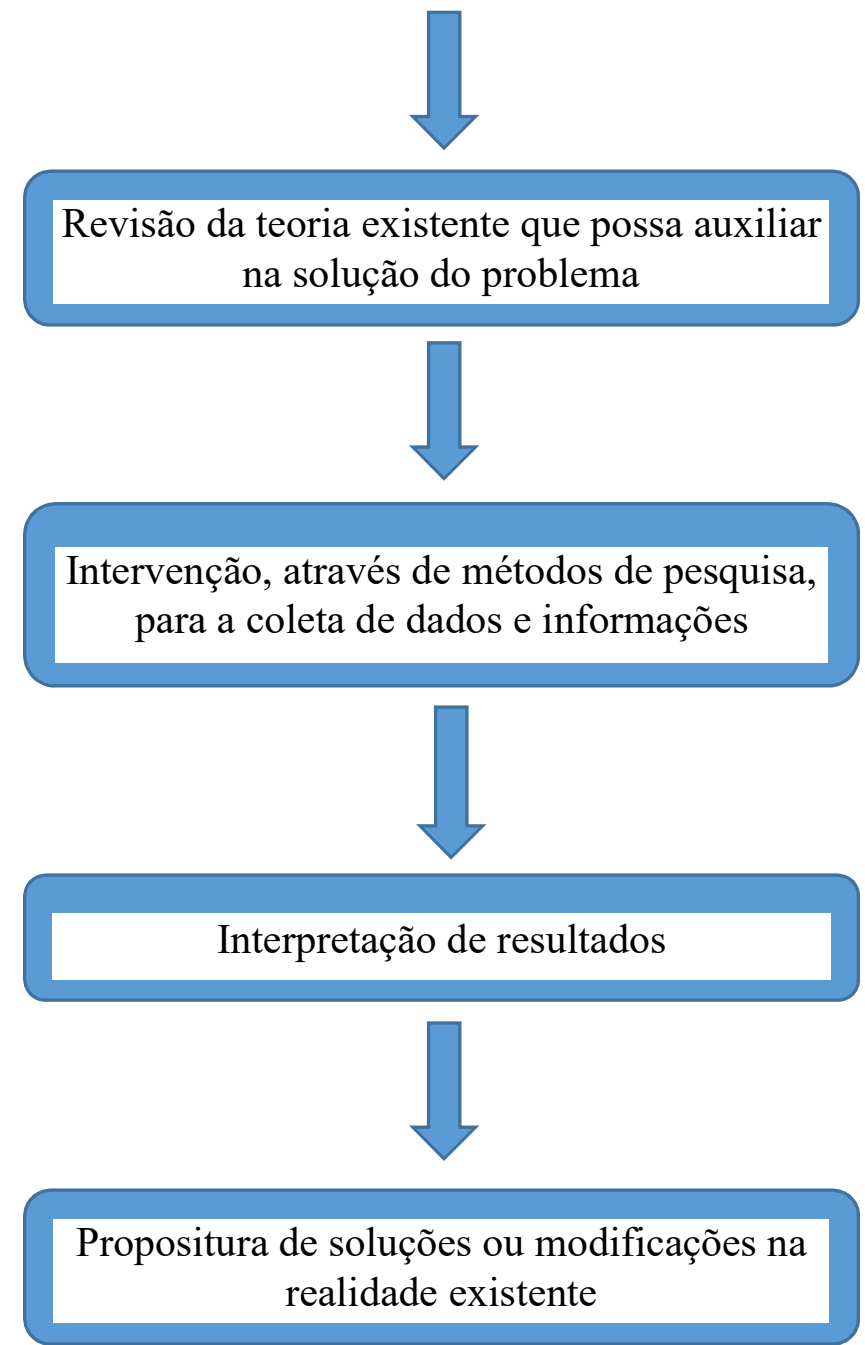

Fonte: Elaborado pelo autor (2018) 
Tendo em vista a natureza do tema a ser pesquisado, e o que se pretende pesquisar, o objetivo desta pesquisa é exploratório, já que, conforme citado por Silva e Menezes (2005), a pesquisa exploratória visa proporcionar maior familiaridade com o problema a fim de levantar hipóteses sobre ele. Esta pesquisa exploratória será feita em diferentes etapas, conforme será detalhado a seguir.

\subsection{Direcionamento da pesquisa}

Sendo o objetivo principal dessa pesquisa o estudo do impacto do programa EMPRETEC em seus participantes, e a real aplicação dos comportamentos preconizados no programa, torna-se vital, para realização do projeto, o estabelecimento de parâmetros para a análise e avaliação das características de comportamento empreendedor, em termos de sua aplicação, e parâmetros de medição e análise dos resultados obtidos com a aplicação dos comportamentos.

Deste modo, o autor decidiu aplicar uma metodologia combinada, com pesquisa qualitativa, seguida de pesquisa quantitativa. Flick (2009) estabelece razões práticas para esta abordagem: "Por fim, no cotidiano da prática de pesquisa, fora das discussões metodológicas frequentemente se faz necessária e útil a ligação entre as duas abordagens por razões pragmáticas" (FLICK, 2009, p. 42).

O aspecto qualitativo da pesquisa está na definição dos parâmetros para a avaliação do impacto e da aplicação dos comportamentos empreendedores, que possam gerar resultados consistentes, e passíveis de interpretação adequada, através da realização de pesquisa com facilitadores (aplicadores) experientes do programa EMPRETEC, além de profissionais envolvidos com o tema do empreendedorismo e educação empreendedora.

Uma vez definidos esses parâmetros, foi realizada uma pesquisa quantitativa, envolvendo a aplicação de um questionário on-line com participantes do programa EMPRETEC, cujos detalhes serão apresentados oportunamente.

\subsection{Métodos e técnicas}


Dada a estruturação da pesquisa na forma de fluxo apresentada anteriormente, e tendo em vista a complexidade do projeto de pesquisa, diferentes métodos e técnicas se tornaram necessários durante as várias etapas da pesquisa, a saber:
a) Pesquisa bibliográfica;
b) Pesquisa Qualitativa;
c) Pesquisa Quantitativa.

\subsubsection{Pesquisa bibliográfica}

A pesquisa bibliográfica, de acordo com Lima e Mioto (2007), “implica em um conjunto ordenado de procedimentos de busca por soluções, atento ao objeto de estudo" (LIMA; MIOTO, 2007, p. 38).

Parte importante desse processo, a revisão da literatura disponível sobre o tema objeto de um estudo é ponto crucial de seu sucesso. É o ponto de partida para uma amarração entre o problema prático encontrado, sobre o qual se deseja estudar, e a fundamentação teórica que pode ajudar a propor soluções.

De acordo com Silva e Menezes (2005), "Uma das etapas mais importantes de um projeto de pesquisa é a revisão de literatura. A revisão de literatura refere-se à fundamentação teórica que você irá adotar para tratar o tema e o problema de pesquisa” (SILVA; MENEZES, 2005, p. 37).

Essa etapa do projeto visa atender a alguns requisitos importantes para dar a base necessária ao estudo, e foi apresentada por Luna (1997) da seguinte forma:

a) Determinação do "estado da arte" - Aqui, procura-se saber "o estado atual de uma dada área de pesquisa: o que já se sabe, quais as principais lacunas, onde se encontram os principais entraves teóricos e/ou metodológicos" (LUNA, 1997, p. 20). Foram identificados diversos trabalhos sobre o tema desse estudo, e eventuais lacunas que permitiram ao autor abordar esse tema, conforme já apresentado em capítulos anteriores;

b) Revisão Teórica - O objetivo dessa etapa é "circunscrever um dado problema de pesquisa dentro de um quadro de referência teórico que pretende explicá-lo" (LUNA, 
1997, p. 20). Nessa etapa, o autor buscou encontrar e apresentar bases teóricas quanto a comportamentos empreendedores, que serviram de base para a fundamentação do trabalho, à educação empreendedora e ao impacto de programas de treinamento;

c) Revisão de Pesquisa Empírica - Em oposição à revisão teórica, e, de certo modo, visando complementá-la, busca-se nesse momento "explicação de como o problema em questão vem sendo pesquisado, especialmente do ponto de vista metodológico, além de fornecer dados resultantes das pesquisas analisadas" (LUNA, 1997, p. 21). A descoberta de trabalhos semelhantes, identificados na etapa 1 descrita acima, permitiu ao autor identificar pontos cruciais na coleta de dados e informações, tanto de caráter qualitativo como quantitativo, e que serão descritos oportunamente.

\subsubsection{Pesquisa qualitativa}

Conforme já apresentado em capítulos anteriores, um dos objetivos desse trabalho é identificar a prática de comportamentos empreendedores em participantes do programa EMPRETEC. Para isso, havia a necessidade de se elaborar um questionário, a ser aplicado de forma on-line, no qual os respondentes declarariam sua autopercepção em relação à prática dos comportamentos.

A base do programa EMPRETEC são as dez CCEs, já apresentadas em capítulos anteriores. Para que o questionário representasse um instrumento efetivo de levantamento de informações, tornou-se necessário elaborá-lo de forma que pudesse apurar a real prática dos comportamentos, sem induzir os participantes em relação às CCEs, já que esses são conceitos já consagrados para eles.

Deste modo, o autor decidiu utilizar uma etapa de pesquisa qualitativa, de forma a construir um questionário robusto e isento de induções. De acordo com Dalfovo et al. (2008), a pesquisa qualitativa "não é traduzida em números, na qual pretende verificar a relação da realidade com o objeto de estudo, obtendo várias interpretações de uma análise indutiva por parte do pesquisador" (DALFOVO et al., 2008, p. 6).

A fim de evitar quaisquer influências nas respostas da fase quantitativa, seria fundamental excluir qualquer menção às CCEs no questionário, pelas razões já apresentadas acima. Assim, foi necessário estabelecer associações entre trabalhos já existentes, e que identificaram e 
levantaram a prática de comportamentos empreendedores, e as CCEs, núcleo central do programa EMPRETEC, para que houvesse formas de se avaliar a prática dos comportamentos apresentados no programa.

Dentre os diversos trabalhos avaliados, um se destacou, na visão do autor, por sua amplitude e ao mesmo tempo profundidade: a escala BOS de comportamentos empreendedores, catalogada por Brown e Hanlon (2004), validada pelos mesmos autores, doze anos depois.

Nesta escala, já apresentada em capítulos anteriores, foram levantadas 9 dimensões e 47 comportamentos empreendedores, através de uma ampla pesquisa com empresários canadenses.

A fim de estabelecer uma associação, ainda que subjetiva, já que o objetivo desta etapa é qualitativo, foi elaborado um questionário, apresentando no apêndice A. Neste primeiro questionário, foram apresentadas aos respondentes as CCEs, base do programa EMPRETEC, e foi solicitado a eles associar essas características de comportamento empreendedor com os comportamentos levantados na escala BOS de Brown e Hanlon (2004), através do preenchimento de uma tabela na qual podiam associar mais de uma CCE a cada um dos 47 comportamentos da escala BOS.

O objetivo da aplicação deste questionário era identificar, dentro da escala BOS, os comportamentos que mais se assemelhavam às CCEs, permitindo a avaliação, ainda que indireta, da prática dessas características de comportamento empreendedor. Além disso, o autor entendeu que submeter um questionário com 47 perguntas sobre comportamentos apenas (sem contar outras perguntas que teriam que ser feitas) resultaria em muitas desistências no preenchimento, e a etapa qualitativa permitiria selecionar comportamentos com maior correlação com as CCEs, que seriam incluídos no segundo questionário, na etapa quantitativa.

Restava a questão dos respondentes a esta etapa. Nicolaci da Costa (2007) menciona em seu trabalho que a primeira fase de uma pesquisa qualitativa representa a seleção da amostra: "Recrutamento dos participantes. Muitos acham que o conceito de amostra se aplica exclusivamente às pesquisas quantitativas. Todos os métodos qualitativos sob investigação, no entanto, transportam este conceito para o campo da pesquisa qualitativa" (NICOLACI DA COSTA, 2007, p. 67). 
Em relação ao tamanho e perfil da amostra, Nicolaci da Costa (2007) igualmente destaca 2 pontos importantes:

[...] as pesquisas qualitativas demandam muita dedicação e tempo [...] Tal demanda, por seu turno, resulta no uso generalizado de amostras pequenas, cujo recrutamento, ao invés de randômico, é quase sempre intencional.

[...] os procedimentos apresentados para realizar esse recrutamento são vários e seguem um de dois princípios básicos: a heterogeneidade ou a homogeneidade de características chave dos participantes (NICOLACI DA COSTA, 2007, p. 67).

Utilizando esses critérios, foram selecionados, nesta etapa, por conveniência do autor, 8 candidatos a respondentes, sendo 2 facilitadores muito experientes do programa EMPRETEC, um ex-facilitador, igualmente experiente, e mais 5 profissionais do campo de empreendedorismo e educação empreendedora, de diferentes instituições. Foi enviado a cada um deles um e-mail, explicando as razões da pesquisa, solicitando sua participação e informando o link para a resposta on-line ao questionário.

Dos 8 candidatos, 2 não responderam ao convite de participação, 1 se recusou a responder a pesquisa, 1 respondeu de forma incompleta, e foram recebidas 4 respostas completas, que foram utilizadas para a avaliação dos resultados.

As respostas completas indicaram um painel muito importante na associação entre comportamentos de 2 fontes diferentes. Para identificar quais comportamentos poderiam ser incluídos no segundo questionário, da pesquisa qualitativa, o autor estabeleceu como critério abordar o maior número possível de CCEs, e escolher comportamentos que tivessem sido associados pelos 4 respondentes, de forma unânime, com as mesmas características de comportamento empreendedor do EMPRETEC.

Destes critérios de seleção, amplitude das CCEs e unanimidade nas respostas, emergiram 27 comportamentos, cobrindo as 10 características de comportamento empreendedor. Para aumentar o índice de respostas na fase quantitativa, o autor decidiu, de forma subjetiva, adotar 20 desses comportamentos apenas, escolhendo aqueles que lhe pareciam mais objetivos, assertivos e simples de compreender. 
Estavam, a partir daí, escolhidos os 20 comportamentos da escala BOS de Brown e Hanlon que fariam parte do segundo questionário, de acordo com o quadro abaixo, com a respectiva associação com as CCEs do programa EMPRETEC:

Tabela 5 - Comportamentos utilizados no segundo questionário

\begin{tabular}{|c|c|}
\hline CCE & COMPORTAMENTO \\
\hline Busca de Informações & Possuo o conhecimento necessário no ramo escolhido \\
\hline Busca de Informações & Obtenho conselhos de outros \\
\hline Busca de Oportunidades e Iniciativa & $\begin{array}{l}\text { Desenvolvo produtos ou serviços para atender às necessidades de } \\
\text { mercado }\end{array}$ \\
\hline Busca de Oportunidades e Iniciativa & $\begin{array}{l}\text { Expando/Expandi o negócio ao identificar novos mercados para os } \\
\text { produtos ou serviços }\end{array}$ \\
\hline Comprometimento & $\begin{array}{l}\text { Estou fisicamente presente e assumo responsabilidade pela gestão } \\
\text { diária do negócio }\end{array}$ \\
\hline Comprometimento & Dedico muitas horas ao negócio \\
\hline Correr riscos calculados & Mantenho um nível de endividamento que o negócio pode sustentar \\
\hline Estabelecimento de Metas & Estabeleço objetivos para o negócio \\
\hline Estabelecimento de Metas & Tenho uma clara visão de para onde o negócio está indo \\
\hline Estabelecimento de Metas & Mantenho-me focado nas prioridades exigidas pelo negócio \\
\hline Exigência de Qualidade e Eficiência & Atendo às expectativas dos clientes \\
\hline Exigência de Qualidade e Eficiência & $\begin{array}{l}\text { Entrego produtos ou serviços que superam as expectativas os } \\
\text { clientes }\end{array}$ \\
\hline Independência e Autoconfiança & Demonstro convicção de que o negócio dará certo \\
\hline Independência e Autoconfiança & Penso que sou automotivado(a) \\
\hline Persistência & Persevero a despeito de obstáculos \\
\hline Persistência & Rapidamente me adapto às mudanças \\
\hline Persuasão e Rede de Contatos & Comunico-me de forma regular com as equipes \\
\hline Persuasão e Rede de Contatos & Construo relacionamentos efetivos com os clientes \\
\hline $\begin{array}{l}\text { Planejamento e Monitoramento } \\
\text { Sistemático }\end{array}$ & Mantenho controles financeiros regulares sobre o negócio \\
\hline $\begin{array}{l}\text { Planejamento e Monitoramento } \\
\text { Sistemático }\end{array}$ & Desenvolvo planos de marketing efetivos \\
\hline
\end{tabular}

Fonte: Elaborado pelo autor ( 2018).

Definidas essas importantes questões, o passo seguinte seria finalizar o questionário, e definir parâmetros para a aplicação da etapa da pesquisa quantitativa, como será apresentado a seguir.

\subsubsection{Pesquisa quantitativa}

Uma vez definidos os comportamentos empreendedores, cuja avaliação permitiria alcançar os objetivos da pesquisa, tornou-se necessário estabelecer uma estratégia de obtenção de dados e informações que pudesse permitir uma análise condizente com esses objetivos. 
Para isso, foi necessário o desenvolvimento de uma etapa de pesquisa quantitativa.

De uma forma geral, tal como a pesquisa experimental, os estudos de campo quantitativos guiam-se por um modelo de pesquisa onde o pesquisador parte de quadros conceituais de referência tão bem estruturados quanto possível, a partir dos quais formula hipóteses sobre os fenômenos e situações que quer estudar. Uma lista de consequências é então deduzida das hipóteses (DALFOVO et al., 2008, p. 7).

De acordo com Silva e Menezes (2005), a pesquisa quantitativa

[...] considera que tudo pode ser quantificável, o que significa traduzir em números, opiniões e informações para classificá-las e analisá-las. Requer o uso de recursos e de técnicas estatísticas (percentagem, média, moda, mediana, desvio-padrão, coeficiente de correlação, análise de regressão, etc.) (SILVA; MENEZES, 2005, p. 20).

Freitas et al. (2000) consideram alguns pontos essenciais na realização de pesquisas quantitativas:

- Amostragem, processo composto pelo contexto, unidade, método da amostragem, e pelo tamanho e seleção da amostra;

- Instrumento de aplicação, em que se deve atentar para o custo, tempo e forma, a fim de garantir uma taxa de resposta aceitável.

\subsubsection{Amostragem e amostra}

A definição da amostragem, ou seja, a escolha de seleção de membros de uma população que possam constituir uma amostra, é fundamental para o sucesso da pesquisa. Segundo Freitas et al. (2000), "alguns aspectos devem ser fortemente considerados, como ter claramente definido o objetivo que se tem com a realização da survey, [...] como definir objetivamente os critérios de elegibilidade dos respondentes" (FREITAS et al., 2000, p. 106).

Tendo em vista o objetivo da pesquisa, de avaliar a prática de comportamentos empreendedores entre os participantes do programa EMPRETEC, e da problemática observada, ou seja, a ausência de trabalhos posteriores à última modificação no formato do programa, ocorrida em 2011, a definição inicial da amostra passou por um critério bastante claro: ter participado do programa EMPRETEC, no estado de São Paulo, a partir de 2011. 
De modo a tornar a avaliação da aplicação dos comportamentos mais proveitosa, o autor decidiu também somente aceitar respostas de participantes que tivessem feito o seminário há pelo menos 6 meses. A aplicação da pesquisa quantitativa teve início a partir do segundo semestre de 2017, o que definiu, de forma clara e objetiva, os critérios de elegibilidade da seguinte forma:

- Participantes do EMPRETEC no estado de São Paulo;

- $\quad$ Entre 2011 e 2016.

O programa EMPRETEC no Brasil “já capacitou cerca de 250 mil pessoas, em mais de 10 mil turmas, distribuídas pelos 27 estados da Federação" (SEBRAE, 2017). Estabelecer uma amostra probabilística, cuja característica "é o fato de todos os elementos da população terem a mesma chance de serem escolhidos" (FREITAS et al., 2000, p. 107), tornou-se virtualmente impossível, dada a complexidade em se obter acesso aos diferentes bancos de dados das unidades estaduais do SEBRAE, além de todo o processo burocrático que envolveria o contato com cada uma dessas unidades e as respectivas autorizações para esse acesso.

Dessa forma, o autor optou em escolher uma amostra não probabilística, em que "nem todos os elementos da população têm a mesma chance de ser selecionados, o que torna os resultados não generalizáveis" (FREITAS et al., 2000, p. 107). Complementando essa escolha, o autor decidiu pela amostragem por conveniência,

[...] que acontece quando são explorados elementos que possuam as informações necessárias e que estejam mais próximos e disponíveis ao pesquisador, podendo o mesmo ser tendencioso na sua seleção e, por conseguinte estes podem diferir da população, contraindicando a sua generalização (HAIR et al. apud FRANCESCONI, 2016, p. 114).

Estando os bancos de dados das unidades estaduais do SEBRAE inalcançáveis, devido às inúmeras questões burocráticas que inviabilizariam o envio do questionário em tempo hábil para a apresentação da pesquisa, o autor lançou mão de sua rede de relacionamentos, que incluía participantes do EMPRETEC, para os quais o autor havia aplicado o programa, além de recorrer, informalmente, a redes semelhantes de colegas facilitadores, todos do estado de São Paulo. 
Tais limitações diminuíram consideravelmente o tamanho da amostra. Ao final dos levantamentos, entre cadastros próprios e de terceiros (colegas facilitadores), foram obtidos pouco mais de 1.200 nomes.

O universo total de participantes do EMPRETEC, desde 1993, é de 250 mil pessoas, o que dá uma média de 10 mil por ano, aproximadamente. O recorte da pesquisa compreende os anos de 2011 a 2016, totalizando cerca de 60 mil participantes nesse período, em todo o território nacional. Se levarmos em conta apenas o estado de São Paulo, teríamos cerca de 20 mil participantes nesse período. A amostra inicial, portanto, representou cerca de $6 \%$ do universo total compreendido no estudo.

Freitas et al. (2000) discorrem sobre o tamanho da amostra, "que se refere ao número de respondentes necessários para que os resultados sejam precisos e confiáveis, e que o tamanho da amostra diminui o erro" (FINK apud FREITAS et al., 2000, p. 109). Existe, ainda, a questão da precisão, em que os mesmos autores afirmam "para dobrar-se a precisão, deve-se quadruplicar o tamanho da amostra" (FREITAS et al., 2000, p. 109).

Não há, entretanto, um padrão estabelecido para dimensionar a amostra, em especial se ela é não probabilística, mas existem algumas leituras mais simplificadas, segundo as quais "com uma amostra inferior a 30 observações se tem chances de se encontrar tanto um valor errôneo ou defasado como um valor próximo da realidade. As chances de obtenção de valores ou resultados alinhados com a realidade aumentam consideravelmente com 100 observações e são ainda bem melhores com 300" (FREITAS et al., 2000, p. 110).

\subsubsection{Instrumento de avaliação}

A importância do instrumento de avaliação no processo de pesquisa se mostrou, para o autor, desde a etapa qualitativa, cujo princípio nesse projeto foi o de fornecer questões que pudessem atingir os objetivos, o principal e os secundários, desse trabalho.

Entre os instrumentos de avaliação usuais, destacam-se, segundo Gil (2002):

- Questionário - Conjunto de questões respondidas por escrito pelo pesquisado;

- Entrevista - Técnica que envolve duas pessoas numa situação "face a face"; 
- Formulário - Pesquisador formula questões previamente elaboradas e anota as respostas.

Ainda de acordo com Gil (2002), "Analisando-se cada uma das três técnicas, pode-se verificar que o questionário constitui o meio mais rápido e barato de obtenção de informações", o que corrobora com Freitas et al. (2000), que destacam a atenção para custo e tempo no processo de obtenção de informações.

Na elaboração do questionário, Gil (2002) destaca cuidados especiais, e define algumas regras práticas:

a) as questões devem ser preferencialmente fechadas, mas com alternativas suficientemente exaustivas para abrigar a ampla gama de respostas possíveis;

b) devem ser incluídas apenas as perguntas relacionadas ao problema proposto;

c) não devem ser incluídas perguntas cujas respostas possam ser obtidas de forma mais precisa por outros procedimentos;

d) devem-se levar em conta as implicações da pergunta com os procedimentos de tabulação e análise dos dados;

e) devem ser evitadas perguntas que penetrem na intimidade das pessoas;

f) as perguntas devem ser formuladas de maneira clara, concreta e precisa;

g) deve-se levar em consideração o sistema de referência do entrevistado, bem como seu nível de informação;

h) a pergunta deve possibilitar uma única interpretação;

i) a pergunta não deve sugerir respostas;

j) as perguntas devem referir-se a uma única ideia de cada vez;

1) o número de perguntas deve ser limitado;

m) o questionário deve ser iniciado com as perguntas mais simples e finalizado com as mais complexas;

n) as perguntas devem ser dispersadas sempre que houver possibilidade de "contágio"; o) convém evitar as perguntas que provoquem respostas defensivas, estereotipadas ou socialmente indesejáveis, que acabam por encobrir sua real percepção acerca do fato; p) na medida do possível, devem ser evitadas as perguntas personalizadas, diretas, que geralmente se iniciam por expressões do tipo "o que você pensa a respeito de...", "na sua opinião..." etc., as quais tendem a provocar respostas de fuga;

q) deve ser evitada a inclusão, nas perguntas, de palavras estereotipadas, bem como a menção a personalidades de destaque, que podem influenciar as respostas, tanto em sentido positivo quanto negativo;

r) cuidados especiais devem ser tomados em relação à apresentação gráfica do questionário, tendo em vista facilitar seu preenchimento;

s) o questionário deve conter uma introdução que informe acerca da entidade patrocinadora, das razões que determinaram a realização da pesquisa e da importância das respostas para atingir seus objetivos;

t) o questionário deve conter instruções acerca do correto preenchimento das questões, preferencialmente com caracteres gráficos diferenciados.

Levando em consideração essas regras e tendo em vista que o objetivo principal dessa pesquisa é o de avaliar o impacto do programa EMPRETEC junto a seus participantes, era importante adicionar às questões comportamentais abordadas na etapa qualitativa formas de confrontar a 
autopercepção dos respondentes com sua realidade cotidiana, para que se pudesse, através de respostas indiretas, confirmar (ou negar) a efetiva prática dos comportamentos que afirmavam fazer.

Para isso, o autor buscou inspiração num trabalho similar, de Reis (2013), no qual são comparadas as 10 CCEs com práticas de gestão, dentro de perfis que correspondem ao MEG, já relatado em capítulo anterior. De uma forma análoga, o autor elaborou 10 questões, cujas repostas seriam posteriormente cruzadas com aquelas dadas em relação aos comportamentos empreendedores.

Para completar o questionário, e extrair posteriormente comparações entre empreendedores de perfil semelhante, o autor decidiu incluir também questões que levantassem um perfil dos respondentes, em relação a gênero, faixa etária, escolaridade, tempo de funcionamento da empresa, setor de atuação, faixa de faturamento anual, e uma questão em particular que poderia permitir uma análise, ainda que de forma descritiva, dos impactos do EMPRETEC nos empreendimentos, como número de colaboradores antes e depois do treinamento.

O questionário foi então agrupado em 3 blocos:

a) Etapa 1 - Dados da empresa e do(a) empreendedor(a) - Nesta etapa, foram levantados dados demográficos dos respondentes, bem como informações referentes ao empreendimento;

b) Etapa 2 - Comportamentos Empreendedores - Nesta etapa, foram aplicadas as questões sobre a prática dos 20 comportamentos definidos na pesquisa qualitativa;

c) Etapa 3 - Práticas de gestão - Nesta etapa, foram feitas perguntas sobre práticas de gestão, para cruzamento posterior com as práticas dos comportamentos da etapa anterior.

\subsubsection{Aplicação do Instrumento de avaliação}

Resolvidas as questões relativas à amostragem e ao instrumento de avaliação da pesquisa quantitativa, havia ainda a etapa de aplicação do questionário propriamente dito. Freitas et al. 
(2002) descrevem algumas formas de fazê-lo, como observação direta, face a face, telefone, correio, multimídia e internet. “[...] as pesquisas realizadas com auxílio da Internet estão ficando cada vez mais populares entre os pesquisadores" (MALHOTRA apud VIEIRA et al., 2010, p. 5). Já em 2010, Vieira et al. (2010) apontam que “[...]Atualmente a Internet está presente na vida de uma parcela significativa de brasileiros".

Os mesmos autores consideram ainda que "As pesquisas on-line podem ser consideradas muito semelhantes metodologicamente às pesquisas realizadas utilizando questionários auto preenchidos ou por telefone, diferindo apenas na maneira como são conduzidas" (VIEIRA et al., 2010, p. 4).

Num estudo feito com pouco mais de 200 participantes para avaliar vantagens e desvantagens do uso de questionários por e-mail, Vieira et al. (2010) chegaram às seguintes conclusões:

a) O questionário ser vinculado a um endereço de e-mail institucional garante mais credibilidade à pesquisa;

b) A maneira de preencher questionários via e-mail é mais fácil que em questionários impressos;

c) Pesquisas por meio do e-mail economizam tempo do respondente;

d) Responder a uma pesquisa on-line agrega conforto e praticidade para o respondente;

e) Um texto bem redigido na introdução ao questionário transmite confiança ao respondente.

Com base nessas conclusões e na facilidade e conveniência em utilizar a internet para o preenchimento dos questionários, o autor decidiu aplicar o questionário de forma on-line. Antes de proceder ao envio dos e-mails, era necessário fazer um pré-teste, envolvendo alguns respondentes, cujo contato com o autor era mais próximo, a fim de que pudessem responder a primeira versão da pesquisa quantitativa, e apresentar sugestões de melhorias. Gil (2002) destaca a importância dessa etapa: “Tão logo o questionário, ou o formulário, ou o roteiro da entrevista estejam redigidos, passa-se a seu pré-teste. Muitos pesquisadores descuidam dessa tarefa, mas somente a partir daí é que tais instrumentos estarão validados para o levantamento" (GIL, 2002, p. 119). 
Esse procedimento se mostrou extremamente importante, visto que vários pequenos detalhes, que passaram despercebidos num primeiro instante, foram devidamente observados por esse pequeno grupo, o que permitiu fazer as correções a tempo, e aplicar um questionário mais robusto e efetivo.

O questionário final foi então elaborado dentro da plataforma de formulários Google ${ }^{\circledR}$, e está apresentado no apêndice B. O envio foi feito em ondas, de 100 respondentes por dia, a fim de evitar problemas de bloqueio da conta de e-mail por suspeita de envio de SPAM. Desde os primeiros envios, houve uma série de retornos por conta de destinatários não encontrados, endereços de e-mail inexistentes ou até caixas postais cheias.

Foram enviadas mensagens de e-mail com o convite à participação na pesquisa e com o link para

o preenchimento (https://docs.google.com/forms/d/16IxC_PyC5KEU9j59EPbP0oeE5EScczhBdE3ioO7Fuk/edi t), para aproximadamente 1.200 endereços de e-mail.

Ao final do primeiro envio para todos os cadastrados na lista de e-mail, foi feita uma avaliação do percentual de respostas, e o autor decidiu reencaminhar o envio, excluindo dessa segunda lista de envios os que já haviam respondido (e mencionado na resposta seu e-mail, o que era facultativo) e os endereços de e-mail rejeitados por diferentes motivos. Essa é, segundo Vieira et al. (2010), uma das vantagens desse tipo de envio: "Os questionários podem ser enviados quantas vezes forem necessárias com maior velocidade” (VIEIRA et al., 2010, p. 6).

As respostas, recebidas de 01/08 a 31/12/2017, totalizaram 307 questionários preenchidos completamente, o que representa um retorno de aproximadamente $25 \%$ dos convites enviados. Deste total, houve 42 respondentes que não se encaixavam no recorte inicial. Embora houvessem passado pelo programa EMPRETEC, estavam fora do período de 2011 a 2016, razão pela qual foram desconsiderados para resposta, ou seja, o próprio questionário, em função da data de participação no programa, os remetia para o final, sem que tivessem a possibilidade de responder a nenhuma outra questão.

Tabela 6 - Percentuais de respostas

\begin{tabular}{l|l|l}
\hline Convites enviados & 1.200 & $100 \%$ \\
\hline Respondidos & 307 & $25,5 \%$ \\
\hline
\end{tabular}




\begin{tabular}{l|l|l}
\hline Rejeitados & 42 & $3,5 \%$ \\
\hline Válidos & 265 & $22 \%$ \\
\hline
\end{tabular}

Fonte: Elaborado pelo autor (2018).

Restaram, portanto, 265 respostas completas, um número considerado satisfatório, de acordo com Freitas et al. (2000). "As chances de obtenção de valores ou resultados alinhados com a realidade aumentam consideravelmente com 100 observações e são ainda bem melhores com 300" (FREITAS et al., 2000, p. 110). 


\section{ANÁLISE DOS DADOS E RESULTADOS}

Neste capítulo, são apresentados os resultados da pesquisa quantitativa, desenvolvida on-line a partir de questionário realizado através dos formulários Google $\AA$, conforme já descrito em capítulo anterior. O questionário da pesquisa quantitativa foi dividido em três etapas:

Quadro 4 - Etapas da pesquisa quantitativa

\begin{tabular}{|c|l|}
\hline Etapa & \multicolumn{1}{c|}{ Dados levantados } \\
\hline 1 & $\begin{array}{l}\text { Dados demográficos dos respondentes, bem como informações referentes ao } \\
\text { empreendimento }\end{array}$ \\
\hline 2 & $\begin{array}{l}\text { Comportamentos Empreendedores - Questões sobre a prática dos 20 } \\
\text { comportamentos definidos na pesquisa qualitativa }\end{array}$ \\
\hline 3 & $\begin{array}{l}\text { Práticas de gestão, para cruzamento posterior com as práticas dos } \\
\text { comportamentos da etapa anterior }\end{array}$ \\
\hline
\end{tabular}

Fonte: Elaborado pelo autor (2018).

\subsection{Análise dos perfis dos respondentes}

Uma série de questões foi proposta aos respondentes a fim de levantar algumas características importantes relativas a eles. Essas perguntas foram divididas em três blocos principais: a data de realização do programa EMPRETEC, dados sobre os empreendimentos dos respondentes, e dados sobre os próprios respondentes. A seguir apresentamos os resultados desse levantamento:

\subsubsection{Período de realização do programa EMPRETEC}

O objetivo dessa primeira pergunta era filtrar, e por consequência excluir da pesquisa, respondentes que tivessem feito o programa antes de 2011 ou depois de 2016, que totalizaram 42, como apresentado no capítulo anterior.

Restaram, portanto, 265 respondentes, cujo perfil de respostas está apresentado na tabela 7 e no gráfico 1 a seguir: 
Tabela 7 - Ano de realização do EMPRETEC

\begin{tabular}{rr|r|r}
\hline Ano de Participação & Totais & Percentuais & \\
\hline 2011 & 4 & $1,5 \%$ \\
\hline 2012 & 2 & $0,8 \%$ \\
\hline 2013 & 17 & $6,4 \%$ \\
\hline 2014 & 26 & $9,8 \%$ \\
\hline 2015 & 83 & $31,3 \%$ \\
\hline 2016 & 133 & $50,2 \%$ \\
\hline & & & \\
\hline Total & $\mathbf{2 6 5}$ & $\mathbf{1 0 0 , 0 \%}$ \\
\hline
\end{tabular}

Fonte: Elaborado pelo autor (2017).

Gráfico 1 - Ano de realização do EMPRETEC

\section{Ano de Realização do Empretec}

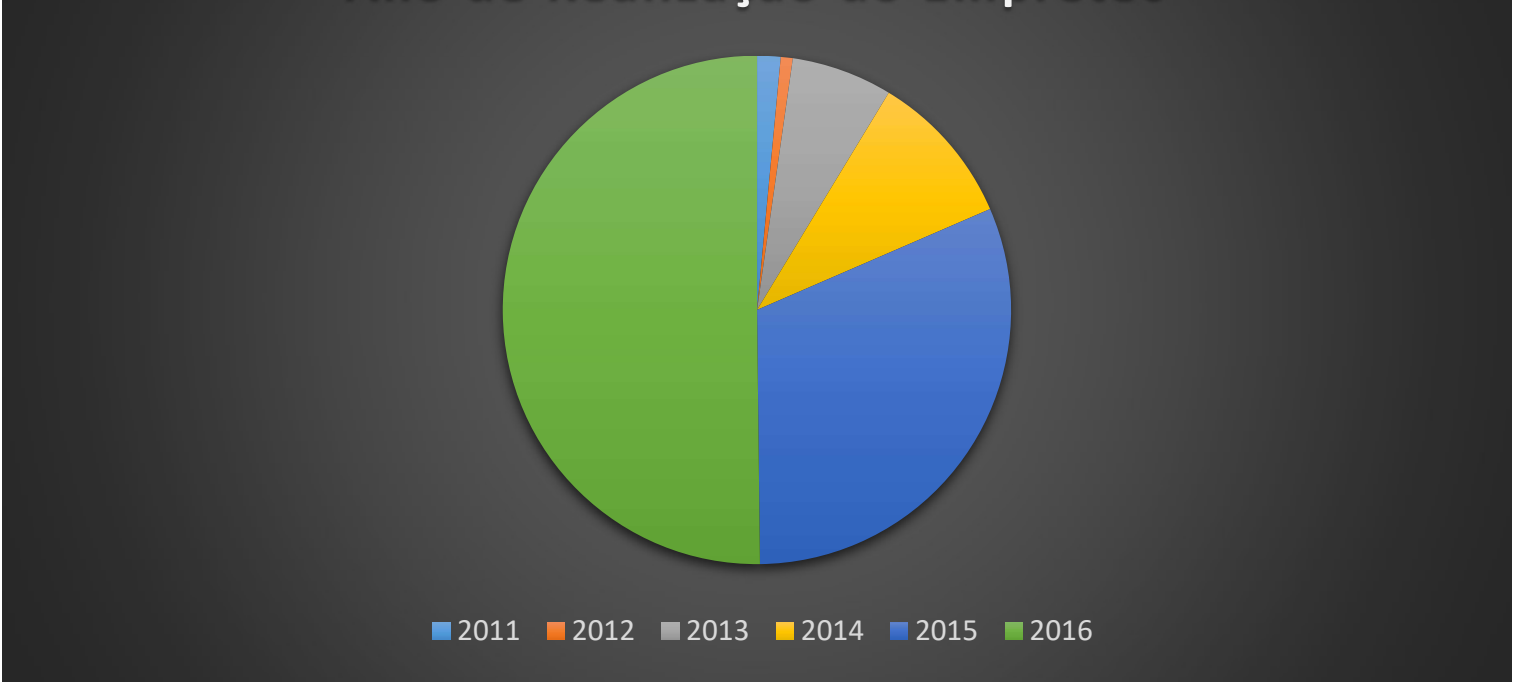

Fonte: Elaborado pelo autor (2018).

Da lista inicial, de aproximadamente 1.200 nomes, não era possível determinar o ano de realização do programa, razão pela qual não se pode fazer nenhuma comparação quanto a essa variável.

Já é possível observar, a partir dessa tabela, que metade dos respondentes participaram do EMPRETEC em 2016, o que indica uma disposição maior em responder tendo em vista o fato de terem realizado o programa há pouco tempo. Vale ressaltar que os bancos de dados utilizados inicialmente visavam homogeneizar a amostra em termos de data de participação no programa. Destaca-se o fato de que os participantes de 2016 representaram metade das respostas, o que pode indicar uma disposição maior para participação em função de terem realizado o programa há pouco tempo. 
4.1.2 Dados sobre os empreendimentos dos respondentes

O objetivo desse levantamento era buscar informações referentes aos empreendimentos, tais como setor de atividade econômica, faixa de faturamento, tempo de funcionamento, número de colaboradores antes e depois da participação no programa EMPRETEC. Estão apresentados, abaixo, os dados obtidos referentes a esses quesitos, nas tabelas e gráficos a seguir:

Tabela 8 - Setor de atividade econômica

\begin{tabular}{l|r|r}
\hline Setor & No. de respondentes & Percentuais \\
\hline Comércio & 63 & $23,8 \%$ \\
\hline Serviços & 181 & $68,3 \%$ \\
\hline Indústria & 19 & $7,2 \%$ \\
\hline Agronegócio & 2 & $0,8 \%$ \\
\hline & & \\
\hline Total & 265 & $100,0 \%$ \\
\hline
\end{tabular}

Fonte: Elaborado pelo autor (2018).

Gráfico 2 - Setor de atuação

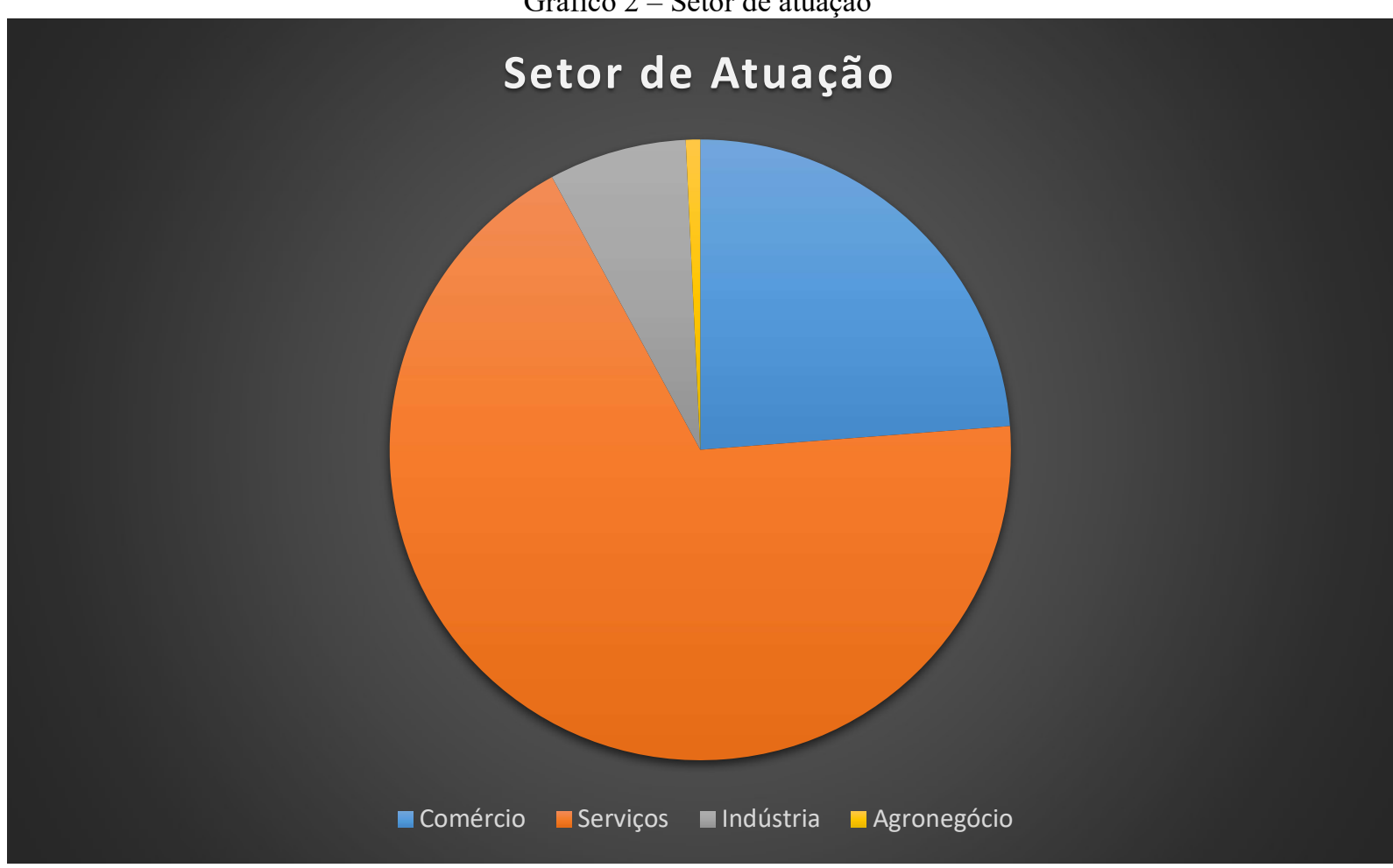

Fonte: Elaborado pelo autor (2018).

O GEM (2016) apresenta uma série de estatísticas sobre o total de empreendedores estabelecidos, que serão utilizadas para comparação com os dados obtidos na pesquisa objeto desse trabalho. 
Quadro 5 - Empreendedores estabelecidos por setor da atividade econômica

Tabela 4.2 - Distribuição percentual dos empreendedores estabelecidos (TEE) segundo o setor da atividade econômica - Países selecionados - 2016

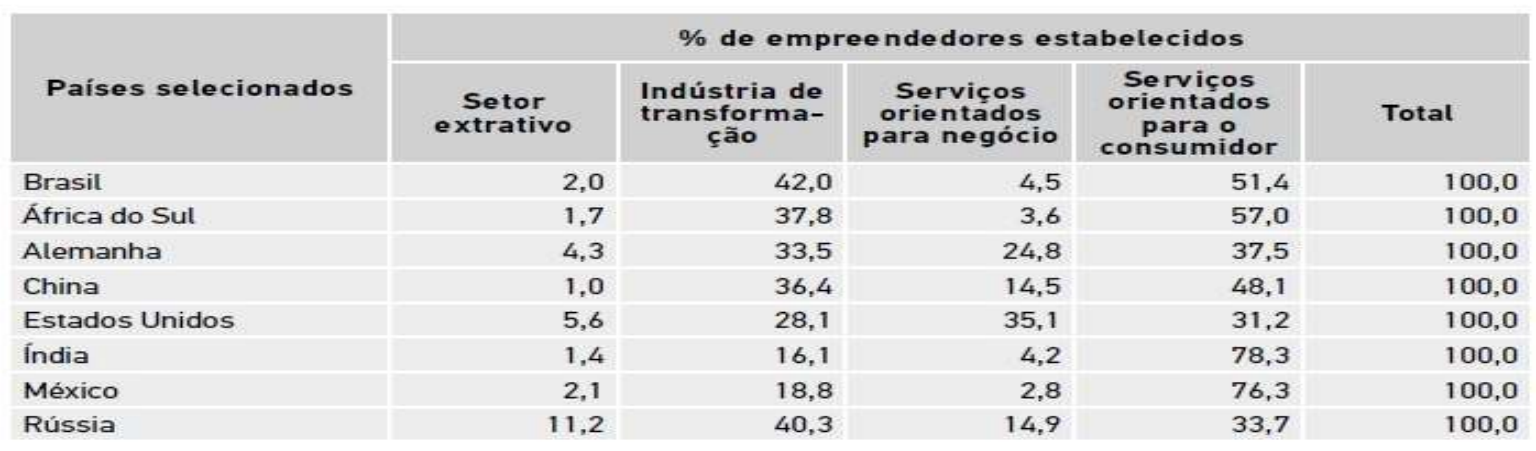

Fonte: GEM Brasil (2016).

As diferenças existentes, em particular em relação ao baixo número de respondentes que têm indústrias e alto número dos que têm empreendimentos prestadores de serviço, podem ser explicadas pelo fato da maior parte dos respondentes ser de São Paulo, capital, onde o número de indústrias caiu significativamente nas últimas décadas, com o correspondente aumento de empresas de prestação de serviços.

Tabela 9 - Faixa de faturamento anual

\begin{tabular}{l|r|r}
\hline Faixa de Faturamento & No. de respondentes & Percentuais \\
\hline Até R\$ 60 mil & 59 & $22,3 \%$ \\
\hline De R \$ 60 mil a R\$ 360 mil & 98 & $37,0 \%$ \\
\hline De R \$ 360 mil a R\$ 1,2 milhão & 55 & $20,8 \%$ \\
\hline De R \$ 1,2 milhão a R\$ 3,6 milhões & 34 & $12,8 \%$ \\
\hline Acima de R\$ 3,6 milhões & 19 & $7,2 \%$ \\
\hline & & \\
\hline Total & 265 & $100,0 \%$ \\
\hline
\end{tabular}

Fonte: Elaborado pelo autor (2018). 
Gráfico 3 - Faixa de faturamento anual

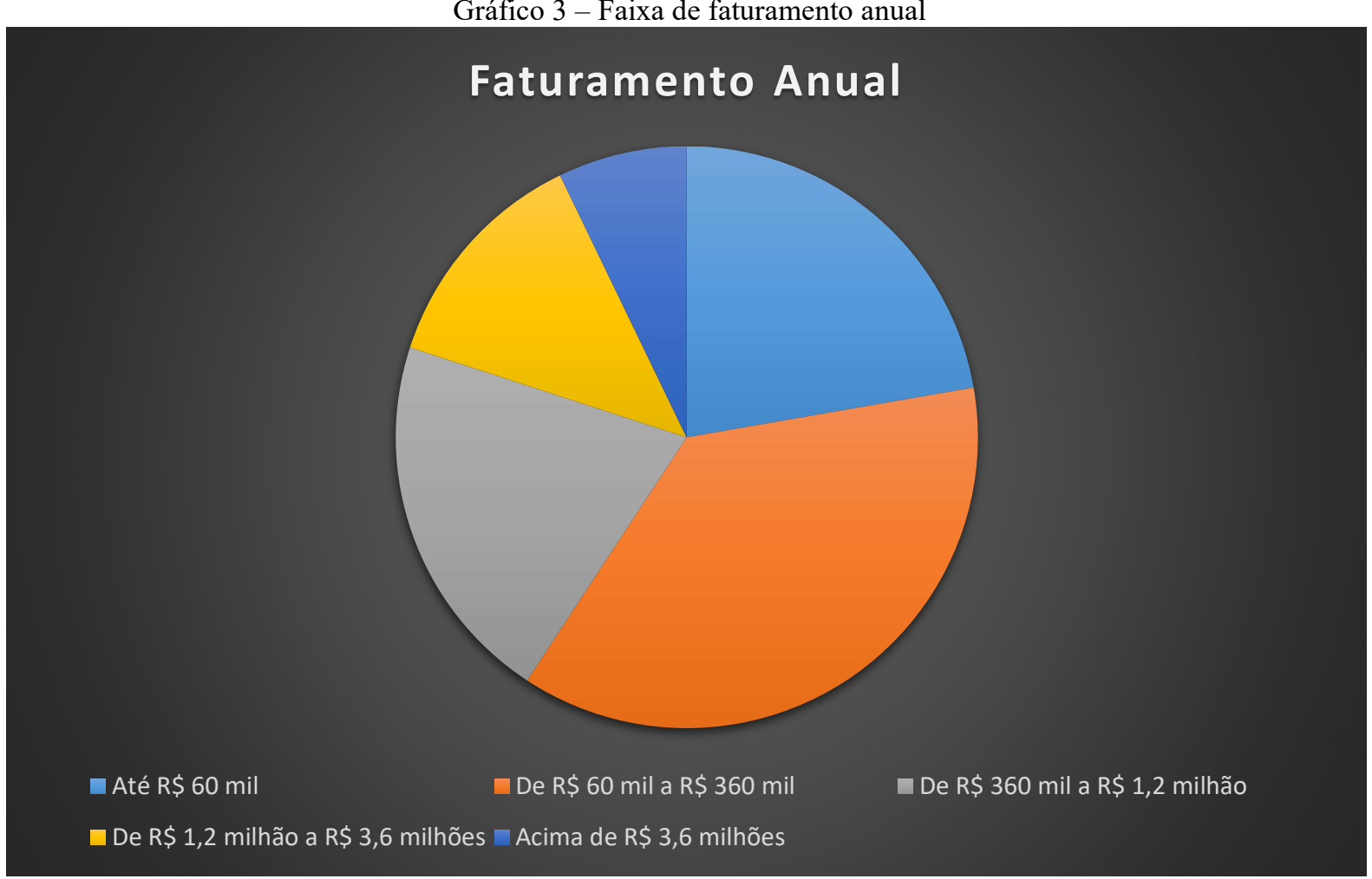

Fonte: Elaborado pelo autor (2018).

O Sebrae apresenta em seu site (SEBRAE, 2017) a seguinte classificação para o enquadramento de empresas:

Quadro 6 - Enquadramento de empresas por faixa de faturamento

\begin{tabular}{|l|l|}
\hline Enquadramento & Faixa de faturamento anual \\
\hline Microempresa & Até R\$ 360.000,00 \\
\hline Empresa de Pequeno porte & Entre R\$ 360.000,00 e R\$ 4.800.000,00 \\
\hline
\end{tabular}

Fonte: Elaborado pelo autor (2018).

Embora haja diferenças entre os critérios adotados na pesquisa e o enquadramento de empresas por faixa de faturamento sugerido pelo Sebrae, é possível observar que $60 \%$ dos respondentes têm microempresas, e microempresas e empresas de pequeno porte somadas representam mais de $90 \%$ do universo dos respondentes. 
Tabela 10 - Número de colaboradores - antes e depois do EMPRETEC

\begin{tabular}{|c|c|c|c|c|}
\hline \multirow[t]{2}{*}{ No. De colaboradores } & \multicolumn{2}{|c|}{ Antes do EMPRETEC } & \multicolumn{2}{|c|}{ Depois do EMPRETEC } \\
\hline & Respondentes & Percentuais & Respondentes & Percentuais \\
\hline Nenhum & 79 & $29,8 \%$ & 22 & $8,3 \%$ \\
\hline $1-5$ & 113 & $42,6 \%$ & 136 & $51,3 \%$ \\
\hline $6-10$ & 25 & $9,4 \%$ & 51 & $19,2 \%$ \\
\hline $11-20$ & 15 & $5,7 \%$ & 28 & $10,6 \%$ \\
\hline $20 \mathrm{ou}+$ & 33 & $12,5 \%$ & 28 & $10,6 \%$ \\
\hline Total & 265 & $100,0 \%$ & 265 & $100,0 \%$ \\
\hline
\end{tabular}

Fonte: Elaborado pelo autor (2018).

Gráfico 4 - Número de colaboradores ANTES e APÓS o EMPRETEC
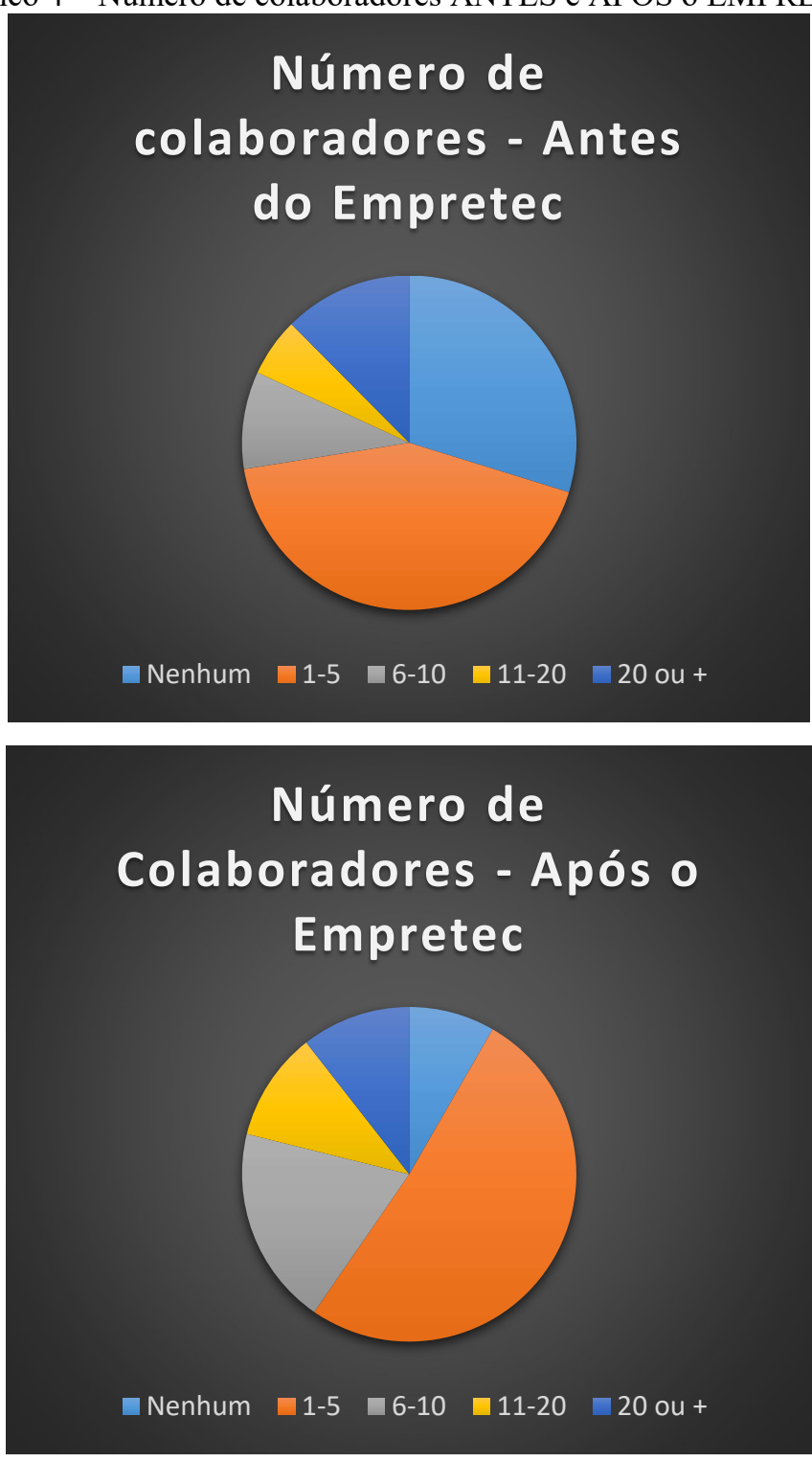

Fonte: Elaborado pelo autor (2018). 
Surgem aqui os primeiros dados numéricos que podem indicar prosperidade nas empresas, após a participação de seus proprietários no EMPRETEC. O número de empresas sem funcionários caiu de $30 \%$ para $8 \%$, um dado bastante significativo, o que fez crescer o número de empresas de 1 a 5 funcionários, de $43 \%$ para $51 \%$ do universo dos respondentes, e mesmo empresas com um número maior de funcionários, entre 6 e 10, e entre 11 e 20, tiveram seus percentuais aumentados de $9 \%$ para $19 \%$, e de $6 \%$ para $11 \%$, respectivamente.

Em pequenos empreendimentos, muitos de base tecnológica baixa, o número de funcionários é um indicador de crescimento, o que indica, através da análise descritiva desses resultados, um impacto da participação no EMPRETEC nos empreendimentos dos participantes.

Tabela 11 - Tempo de funcionamento da empresa

\begin{tabular}{l|r|r}
\hline \multicolumn{1}{c|}{ Tempo de funcionamento } & Respondentes & \multicolumn{2}{c}{ Percentuais } \\
\hline Menos de 1 ano & 12 & $4,5 \%$ \\
\hline $1-5$ anos & 135 & $50,9 \%$ \\
\hline $6-10$ anos & 49 & $18,5 \%$ \\
\hline 10 anos ou mais & 69 & $26,0 \%$ \\
\hline & & $100,0 \%$ \\
\hline Total & 265 & \\
\hline
\end{tabular}

Fonte: Elaborado pelo autor (2018).

Gráfico 5 - Tempo de funcionamento da empresa

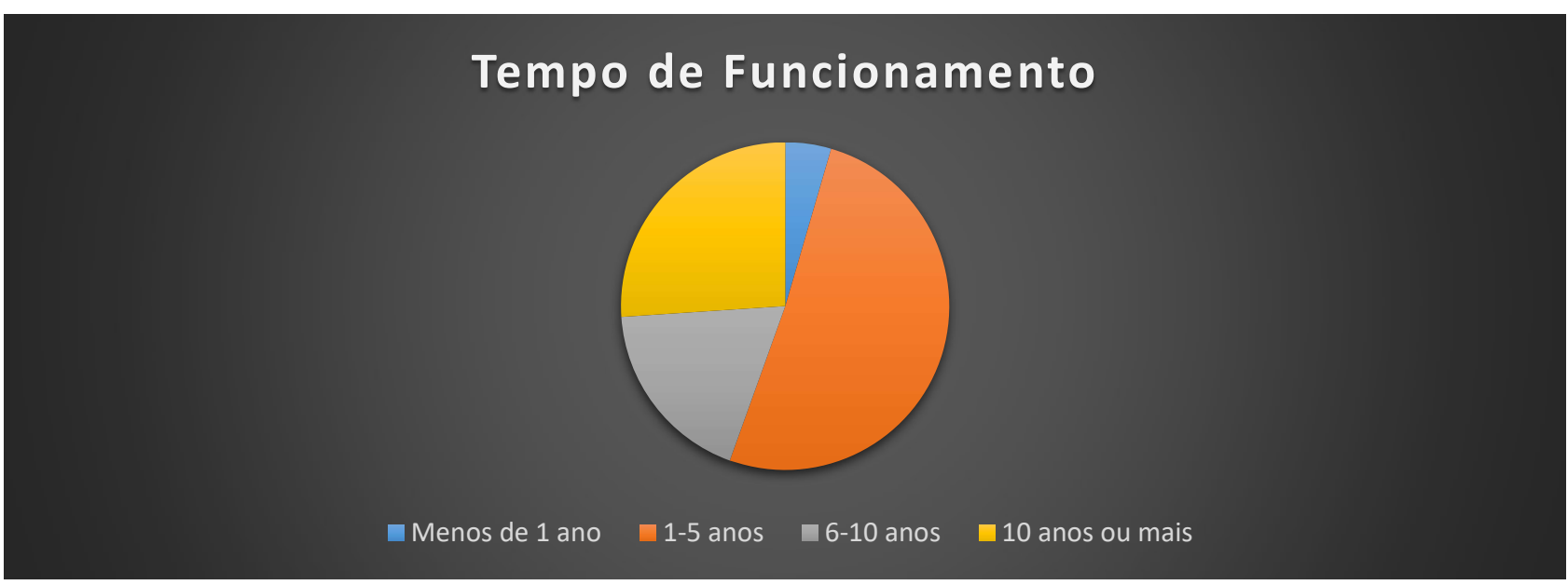

Fonte: Elaborado pelo autor (2018).

É possível perceber, a partir desses dados, que cerca de 56\% dos respondentes têm empresa há 5 anos, ou menos. Levando em consideração que participaram do EMPRETEC entre 2011 e 2016, é possível perceber que decidiram participar do programa nos estágios iniciais do seu 
empreendimento, o que pode denotar uma preocupação em se preparar adequadamente para conduzir uma empresa.

\subsubsection{Dados demográficos dos respondentes}

Os respondentes apresentaram os seguintes perfis demográficos, de acordo com as tabelas e gráficos que seguem. Em termos de gênero (masculino e feminino), os respondentes se distribuíram de acordo com a tabela e o gráfico a seguir:

Tabela 12 - Gênero dos respondentes

\begin{tabular}{l|r|r}
\hline Gênero & Respondentes & \multicolumn{2}{|c}{ Percentuais } \\
\hline Masculino & 170 & $64,2 \%$ \\
\hline Feminino & 95 & $35,8 \%$ \\
\hline & & 265 \\
\hline Totais & & $100,0 \%$ \\
\hline
\end{tabular}

Fonte: Elaborado pelo autor (2018).

Gráfico 6-Gênero dos respondentes

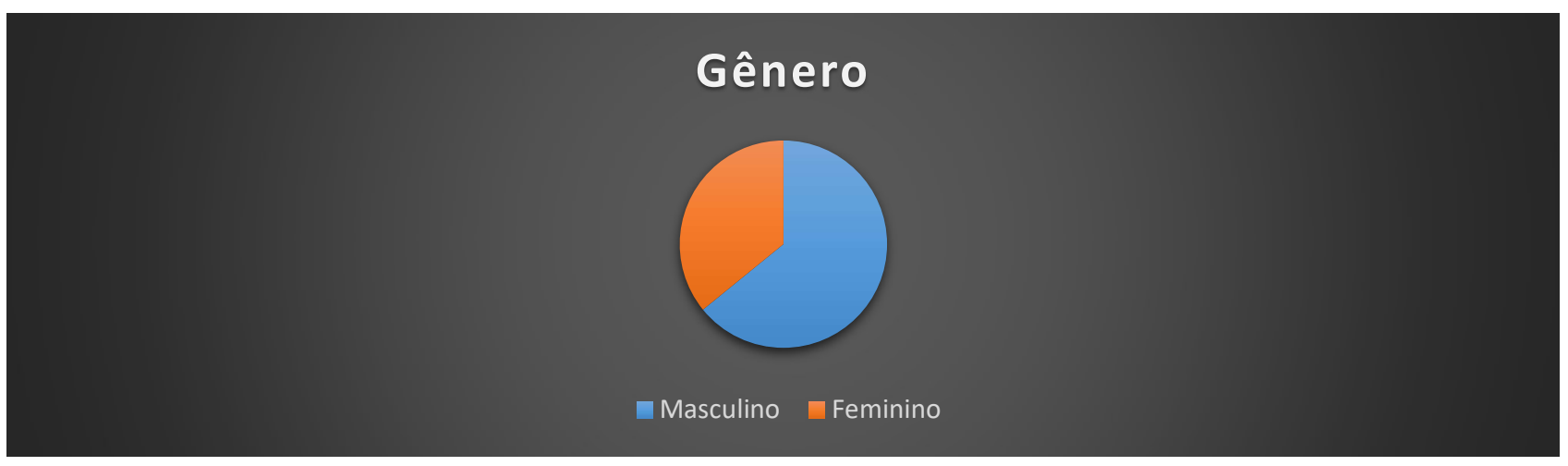

Fonte: Elaborado pelo autor (2018).

O GEM (2016) apresenta estatísticas em relação ao percentual de empreendedores estabelecidos (TEE), de acordo com o gênero, conforme indicado no quadro a seguir: 
Quadro 7 - Percentual de empreendedores estabelecidos por gênero

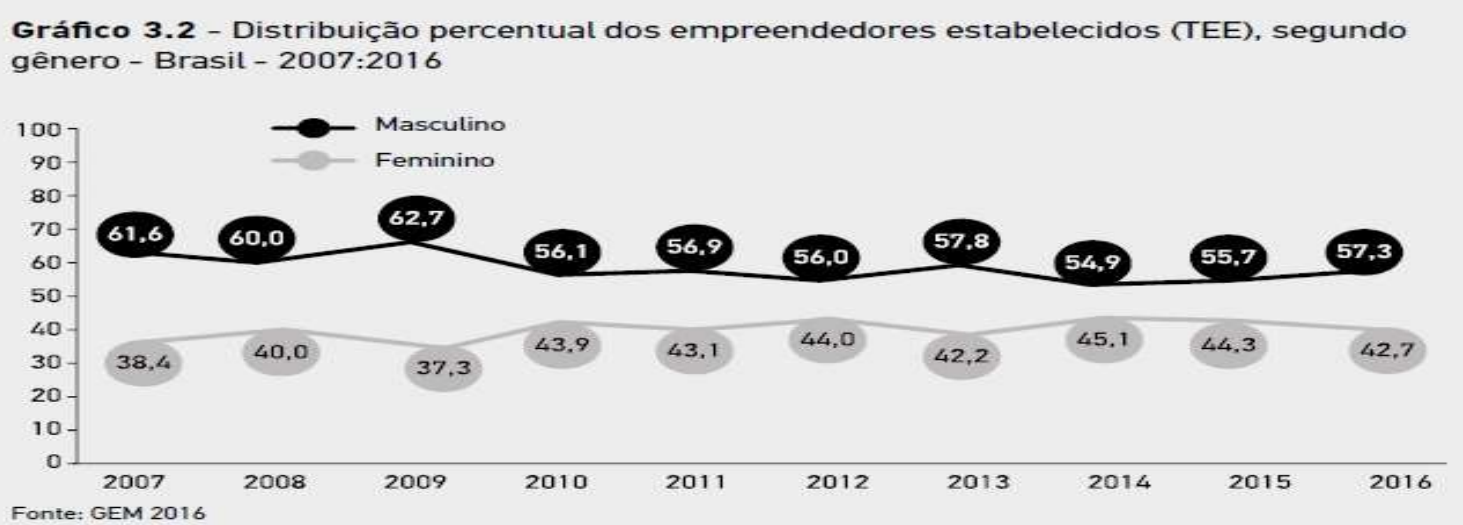

Fonte: GEM (2016).

A partir desses dados, é possível perceber que a proporção encontrada na amostra não corresponde àquela levantada pela pesquisa do GEM (2016). Jonathan e Silva (2007) descrevem uma situação que pode explicar, ao menos em parte, essa discrepância:

Embora não fossem os mais frequentemente mencionados, os conflitos família $\mathrm{x}$ trabalho foram considerados os mais problemáticos e difíceis de equacionar. Neste contexto, o sentimento de culpa que ocasionalmente emergiu tendia a se vincular a dificuldades já superadas, sendo a culpa remetida ao passado (JONATHAN; SILVA, 2007, p. 80).

A realidade mostra a dificuldade em conciliar os conflitos família $\mathrm{x}$ empreendimento, o que por si só já inibe a presença das mulheres no empreendedorismo. Se já não é fácil lidar com esses conflitos, abrir mão do empreendimento e da família durante uma semana, bastante intensa e demandante em termos de horário e comprometimento, faz com que as mulheres ainda sejam minoria nas salas do EMPRETEC.

Tabela 13 - Faixas etárias dos respondentes

\begin{tabular}{l|r|r}
\hline Faixa Etária & Respondentes & \multicolumn{2}{|c}{ Percentual } \\
\hline 18 a 24 anos & 1 & $0,4 \%$ \\
\hline 25 a 34 anos & 73 & $27,5 \%$ \\
\hline 35 a 50 anos & 145 & $54,7 \%$ \\
\hline 51 a 65 anos & 45 & $17,0 \%$ \\
\hline Acima de 65 anos & 1 & $0,4 \%$ \\
\hline & & $100,0 \%$ \\
\hline Totais & 265 & \\
\hline
\end{tabular}

Fonte: Elaborado pelo autor (2018). 
Gráfico 7 - Faixa etária dos respondentes

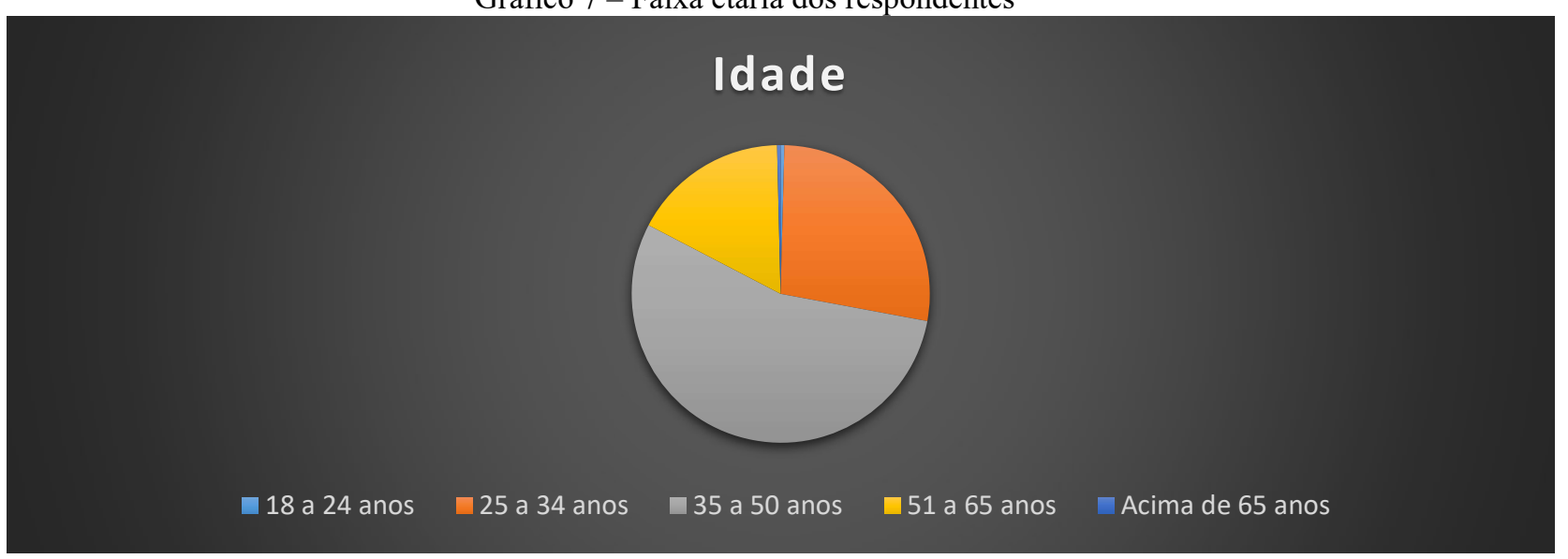

Fonte: Elaborado pelo autor (2018).

Uma comparação desses resultados com trabalhos anteriores, como os de Reis (2013) e Alvim (2007) não apresentou diferenças significativas nas faixas etárias dos respondentes.

Da mesma forma que por gênero, é possível também comparar os dados demográficos obtidos com os apresentados pelo GEM (2016), de acordo com o quadro a seguir:

Quadro 8 - Distribuição dos empreendedores estabelecidos (TEE) por faixa etária

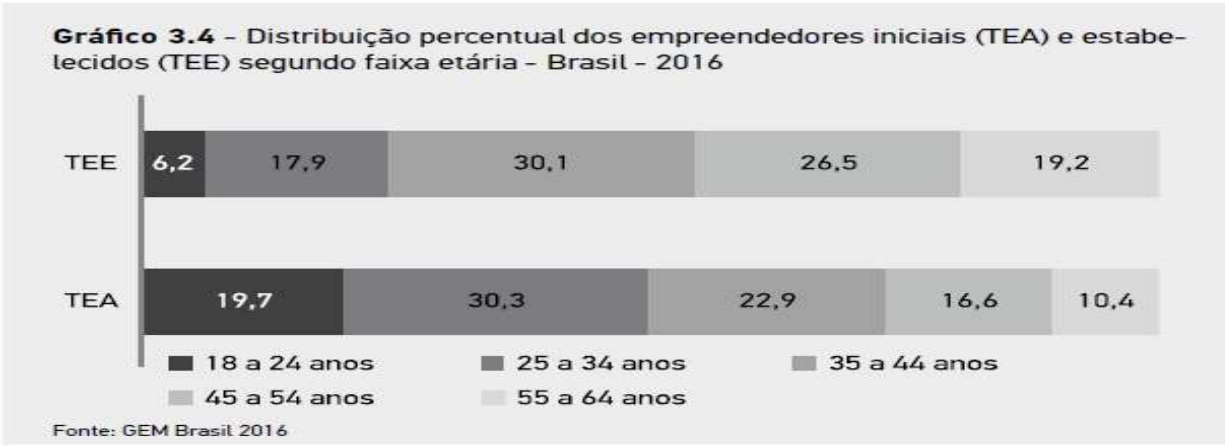

Fonte: GEM (2016).

Embora o critério de divisão das faixas etárias não tenha sido o mesmo, é igualmente possível perceber diferenças entre os dados apresentados pelo GEM (2016) e aqueles obtidos na pesquisa objeto desse trabalho, em especial na faixa de 18 a 24 anos. Embora haja cada vez mais empreendedores nessa faixa etária, o que mostra a presença de quase $20 \%$ na taxa de empreendedores iniciais (TEA), tal proporção não se repete entre os respondentes. Num trabalho sobre pedagogia empreendedora, Frederick (2007) destaca vários aspectos sobre educação empreendedora para jovens, denominados no referido trabalho como "Geração Y": 
Revisões "Wiki" (modo colaborativo de troca de informações), séries de vídeos, lições de Hollywood (aprendendo empreendedorismo através de filmes), entrevistas com empreendedores, e estudos de caso. Ainda que a baixa presença de jovens entre 18 e 24 anos não seja objeto desse estudo, é importante refletir a partir dessas indicações, em relação ao programa EMPRETEC, que tem 30 anos de existência, e talvez não seja atrativo para esse perfil de público.

A seguir, apresentamos os dados obtidos referentes ao grau de escolaridade dos respondentes, conforme tabela e gráfico abaixo:

Tabela 14 - Grau de escolaridade dos respondentes

\begin{tabular}{l|r|r}
\hline Grau de escolaridade & Respondentes & Percentual \\
\hline Ensino Fundamental & 2 & $0,8 \%$ \\
\hline Ensino Médio & 35 & $13,2 \%$ \\
\hline Ensino Superior & 98 & $37,0 \%$ \\
\hline Pós-Graduação & 130 & $49,1 \%$ \\
\hline & & \\
\hline Totais & 265 & $100,0 \%$ \\
\hline
\end{tabular}

Fonte: Elaborado pelo autor (2018).

Gráfico 8 - Grau de escolaridade dos respondentes

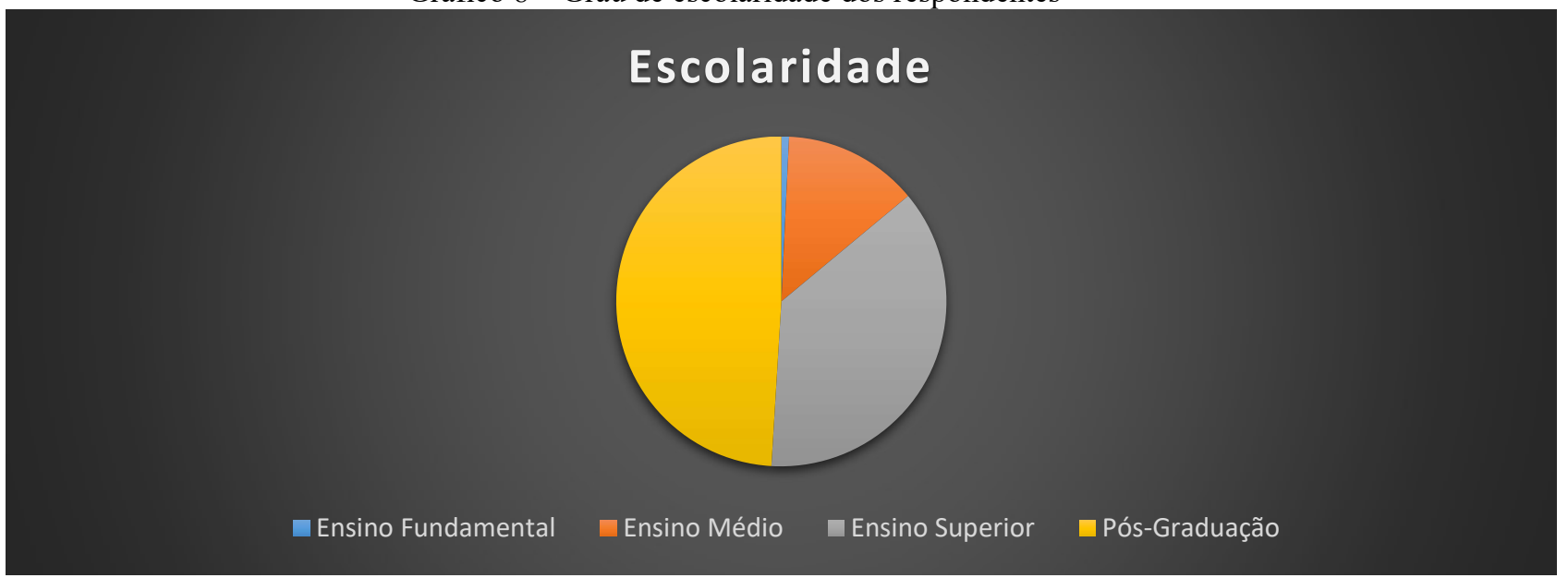

Fonte: Elaborado pelo autor (2018).

É possível igualmente comparar os dados relativos à escolaridade com aqueles apresentados pelo GEM (2016), conforme quadro a seguir: 
Gráfico 3.5 - Distribuição percentual dos empreendedores iniciais (TEA) e estabelecidos (TEE) segundo nível de escolaridade' - Brasil - 2016

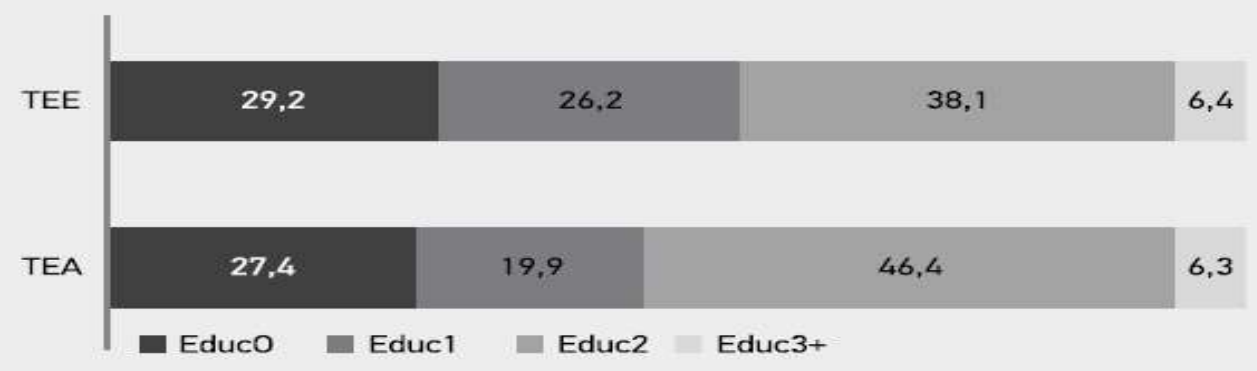

Fonte: GEM Brasil 2016

${ }^{\mathrm{t}}$ Educ0 $=$ Nenhuma educação formal e ensino fundamental incompleto: Educ1 = Ensino fundamental completo e ensino médio incompleto: Educ2 = Ensino médio completo e superior incompleto: Educ3+ = Superior completo, especialização incompleta e completa, mestrado incompleto e completo, doutorado incompleto e doutorado completo

Fonte: GEM (2016).

Nos dados obtidos pela pesquisa, há diferenças importantes em relação àqueles apresentados pelo GEM (2016), notadamente na presença de quase metade dos respondentes com PósGraduação, contra pouco mais de 6\% do GEM (2016), e naqueles que, segundo o GEM (2016), têm nenhuma educação formal ou ensino fundamental incompleto, e que representam quase $30 \%$, enquanto apenas 2 respondentes indicaram ensino fundamental na pesquisa objeto desse trabalho. A mesma diferença é apontada por Oliveira (2013), ao identificar perfis de microempreendedores individuais. "Os indivíduos que fazem essa transição, muitas vezes sem alternativa, tendem a ser aqueles com mais baixa escolaridade, com menor renda e com mais idade. Tal processo aparentemente se concentra em segmentos econômicos intensivos em mão de obra de baixa produtividade" (OLIVEIRA, 2013, p. 43).

Analisando os dados demográficos e perfis dos empreendimentos quando comparados com uma estatística bem mais abrangente, como a do GEM (2016), é possível perceber diversas diferenças:

a) Jovens, em especial de 18 a 24 anos, estão presentes, ao menos na amostra apresentada, numa proporção muito mais baixa que nas estatísticas do GEM (2016), o que pode indicar uma baixa atratividade do programa EMPRETEC;

b) Empreendedores com baixa escolaridade representam uma altíssima minoria da amostra pesquisada, em relação aos dados apresentados pelo GEM (2016), o que pode sugerir uma certa elitização do programa, que talvez ocorra ainda na sua fase de recrutamento e seleção dos participantes;

c) A presença bem menor de mulheres, dentro da amostra pesquisada, quando comparado com os dados do GEM (2016), pode indicar a dificuldade em participar de um programa bastante intenso e demandante, em função das múltiplas atividades presentes no cotidiano feminino. 


\subsection{Comportamentos Empreendedores}

O objetivo principal do presente trabalho era o de estudar o impacto do programa EMPRETEC, e sua relação com a prática das 10 características de comportamento empreendedor do programa. Dessa forma, era necessário apurar a efetiva prática desses comportamentos.

Para isso, foram apresentadas aos respondentes 20 questões, nas quais foram feitas autoavaliações por parte dos entrevistados, conforme já descrito anteriormente.

A tabela 15 a seguir mostra a compilação geral sobre a prática dos comportamentos empreendedores.

$\mathrm{Na}$ referida tabela, são apresentados os comportamentos empreendedores utilizados para a formação do questionário, sua respectiva associação com as CCEs do programa EMPRETEC, as frequências das respostas, seus percentuais, a média, moda e mediana de cada comportamento analisado. 
Tabela 15 - Tabulação Geral dos Comportamentos

\begin{tabular}{|c|c|c|c|c|c|c|c|c|c|c|c|c|c|c|}
\hline CCE & COMPORTAMENTO & Nunc & & Raram & ente & Àsve & & Usuain & mente & Sem & & Média & Moda & Mediana \\
\hline Busca de Informações & Possuo o conhecimento necessario no ramo escolhido & & $0,0 \%$ & 5 & $1,9 \%$ & 14 & $5,3 \%$ & 99 & $37,4 \%$ & 147 & $55,5 \%$ & 4,46 & & \\
\hline Busca de Informações & Obtenho consethos de outros & & $0,0 \%$ & 8 & $3,0 \%$ & 45 & $17,0 \%$ & 125 & $47,2 \%$ & 87 & $32,8 \%$ & 4,10 & 4 & \\
\hline Busca de Oportunidades e Iniciativa & Desenvolvo produtos ou serviços para atender às necessidades de mercado & & $0,0 \%$ & 6 & $2,3 \%$ & 31 & $11,7 \%$ & 104 & $39,2 \%$ & 124 & $46,8 \%$ & 4,31 & 5 & 5 \\
\hline Busca de Oportunidades e Iniciativa & Expando Expandi o negócio ao identificar novos mercados para os produtos ou serviços & 8 & $3,0 \%$ & 22 & $8,3 \%$ & 51 & $19,2 \%$ & 96 & $36,2 \%$ & 88 & $33,2 \%$ & 3,88 & & \\
\hline Comprometimento & Estou fisicamente presente e assumo responsabilidade pela gestào diảria do negócio & 2 & $0,8 \%$ & 6 & $2,3 \%$ & 21 & $7,9 \%$ & 65 & $24,5 \%$ & 171 & $64,5 \%$ & 4,50 & & \\
\hline Comprometimento & Dedico muitas horas ao negócio & 1 & $0,4 \%$ & 7 & $2,6 \%$ & 29 & $10,9 \%$ & 73 & $27,5 \%$ & 155 & $58,5 \%$ & 4,41 & 5 & 5 \\
\hline Correr Riscos Calculados & Mantenho um nivel de endividamento que o negócio pode sustentar & 11 & $4,2 \%$ & 19 & $7,2 \%$ & 43 & $16,2 \%$ & 62 & $23,4 \%$ & 130 & $49,1 \%$ & 4,06 & 5 & \\
\hline Estabelecimento de Metas & Estabeleço objetivos para o negócio & 0 & $0,0 \%$ & 15 & $5,7 \%$ & 53 & $20,0 \%$ & 108 & $40,8 \%$ & 89 & $33,6 \%$ & 4,02 & & \\
\hline Estabelecimento de Metas & Tenho uma clara visão de para onde o negócio estả indo & 3 & $1,1 \%$ & 16 & $6,0 \%$ & 46 & $17,4 \%$ & 114 & $43,0 \%$ & 86 & $32,5 \%$ & 4,00 & & \\
\hline Estabelecimento de Metas & Mantenho-me focado nas prioridades exigidas pelo negócio & & $0,0 \%$ & 8 & $3,0 \%$ & 50 & $18,9 \%$ & 122 & $46,0 \%$ & 85 & $32,1 \%$ & 4,07 & & \\
\hline Exigência de Qualidade e Eficiencia & Atendo às expectativas dos clientes & & $0,4 \%$ & 5 & $1,9 \%$ & 22 & $8,3 \%$ & 136 & $51,3 \%$ & 101 & $38,1 \%$ & 4,25 & & \\
\hline Exigencia de Qualidade e Eficiencia & Entrego produtos ou serviços que superam as expectativas os clientes & 2 & $0,8 \%$ & 7 & $2,6 \%$ & 28 & $10,6 \%$ & 140 & $52,8 \%$ & 88 & $33,2 \%$ & 4,15 & & \\
\hline Independencia e Autoconfiança & Demonstro convicção de que o negócio dara certo & 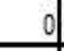 & $0,0 \%$ & 6 & $2,3 \%$ & 19 & $7,2 \%$ & 71 & $26,8 \%$ & 169 & $63,8 \%$ & 4,52 & & \\
\hline Independência e Autoconfiança & Penso que sou auto motivado(a) & 2 & $0,8 \%$ & 4 & $1,5 \%$ & 46 & $17,4 \%$ & 101 & $38,1 \%$ & 112 & $42,3 \%$ & 4,20 & 5 & \\
\hline Persistência & Rapidamente me adapto às mudanças & 5 & $1,9 \%$ & 10 & $3,8 \%$ & 56 & $21,1 \%$ & 103 & $38,9 \%$ & 91 & $34,3 \%$ & 4,00 & 4 & \\
\hline Persistência & Persevero a despeito de obstáculos & & $0,4 \%$ & 4 & $1,5 \%$ & 11 & $4,2 \%$ & 87 & $32,8 \%$ & 162 & $61,1 \%$ & 4,53 & & \\
\hline Persuasão e Rede de Contatos & Comunico-me de forma regular com as equipes & & $1,9 \%$ & 14 & $5,3 \%$ & 38 & $14,3 \%$ & 97 & $36,6 \%$ & 111 & $41,9 \%$ & 4,11 & & \\
\hline Persuasão e Rede de Contatos & Construo relacionamentos efetivos com os clientes & & $1,9 \%$ & 8 & $3,0 \%$ & 29 & $10,9 \%$ & 105 & $39,6 \%$ & 118 & $44,5 \%$ & 4,22 & & \\
\hline Planejamento e Monitoramento Sistemáticos & Mantenho controles financeiros regulares sobre o negócio & & $1,1 \%$ & 25 & $9,4 \%$ & 39 & $14,7 \%$ & 83 & $31,3 \%$ & 115 & $43,4 \%$ & 4,06 & & \\
\hline Planejamento e Monitoramento Sistemáticos & Desenvolvo planos de marketing efetivos & 10 & $3,8 \%$ & 44 & $16,6 \%$ & 71 & $26,8 \%$ & 107 & $40,4 \%$ & 33 & $12,5 \%$ & 3,41 & & \\
\hline
\end{tabular}

Fonte: Elaborado pelo autor (2018). 
A análise dos resultados apresentados foi realizada utilizando 3 diferentes medidas de tendência utilizadas em estatística:

- Média - Foi feito o cálculo da média ponderada, onde foram atribuídos os seguintes pesos: 1-Nunca, 2-Raramente, 3-Às vezes, 4-Usualmente e 5-Sempre;

- Moda - Esta medida indica o valor mais frequente do conjunto de dados apresentado, ou seja, em qual posição da escala Likert adotada as respostas mais frequentes eram apresentadas;

- Mediana - Para o cálculo da mediana, foi utilizado o total de respondentes válidos, 265, e verificado em que posição da escala Likert aparecia a resposta número 133, que seria a posição central das respostas.

Quando se trata de Escala Likert e as análises estatísticas decorrentes dela, há bastante controvérsia envolvida. De um lado, por exemplo, Kuzon et al. (1996), que apontam que um dos 7 pecados em análise estatística é "utilizar estatística paramétrica em dados ordinais" (KUZON et al., 1996, p. 1) (Tradução pelo autor), caso da escala Likert, e de outro Norman (2010), que conclui em seu trabalho que "estatística paramétrica pode ser utilizada em escalas Likert, com amostras de tamanho pequeno, [...], sem medo de se chegar a conclusões erradas" (NORMAN, 2010, p. 10, tradução nossa).

Do ponto de vista estatístico, não foi intuito do autor se aprofundar em análises detalhadas, mas sim em descrever os resultados encontrados, em função da natureza dos dados obtidos, do tamanho da amostra e do próprio objetivo principal desse estudo.

Com base nos primeiros resultados apresentados na tabela 15 acima, é possível perceber que moda e mediana se aproximam bastante, coincidindo em 14 dos 20 comportamentos analisados. Entretanto, esses valores do ponto de vista descritivo não oferecem instrumentos de comparação da intensidade entre as diferentes CCEs, embora evidenciem uma prática bastante efetiva dos comportamentos empreendedores após a passagem pelo programa EMPRETEC, do ponto de vista da autopercepção dos respondentes. Essa autopercepção será confrontada com 10 indicadores que serão apresentados ainda nesse capítulo.

Em função disso, o autor optou pela escolha de média ponderada para fazer uma análise descritiva da distinção entre as CCEs, no que se refere à intensidade da prática dos 
comportamentos empreendedores. A tabela 16 a seguir apresenta as CCEs, ordenadas em ordem decrescente pela média ponderada:

Tabela 16 - CCEs por média ponderada

\begin{tabular}{|c|c|c|c|c|c|c|c|c|c|c|c|}
\hline $\mathrm{CCE}$ & \multicolumn{2}{|c|}{ Nunca } & \multicolumn{2}{|c|}{ Raramente } & \multicolumn{2}{|c|}{ Às vezes } & \multicolumn{2}{|c|}{ Usualmente } & \multicolumn{2}{|c|}{ Sempre } & Média \\
\hline Comprometimento & 3 & $0,6 \%$ & 13 & $2,5 \%$ & 50 & $9,4 \%$ & 138 & $26,0 \%$ & 326 & $61,5 \%$ & 4,45 \\
\hline $\begin{array}{l}\text { Independência e } \\
\text { Autoconfiança }\end{array}$ & 2 & $0,4 \%$ & 10 & $1,9 \%$ & 65 & $12,3 \%$ & 172 & $32,5 \%$ & 281 & $53,0 \%$ & 4,36 \\
\hline $\begin{array}{l}\text { Busca de } \\
\text { Informações }\end{array}$ & 0 & $0,0 \%$ & 13 & $2,5 \%$ & 59 & $11,1 \%$ & 224 & $42,3 \%$ & 234 & $44,2 \%$ & 4,28 \\
\hline Persistência & 6 & $1,1 \%$ & 14 & $2,6 \%$ & 67 & $12,6 \%$ & 190 & $35,8 \%$ & 253 & $47,7 \%$ & 4,26 \\
\hline $\begin{array}{l}\text { Exigência de } \\
\text { Qualidade e } \\
\text { Eficiência }\end{array}$ & 3 & $0,6 \%$ & 12 & $2,3 \%$ & 50 & $9,4 \%$ & 276 & $52,1 \%$ & 189 & $35,7 \%$ & 4,20 \\
\hline $\begin{array}{l}\text { Persuasão e Rede de } \\
\text { Contatos }\end{array}$ & 10 & $1,9 \%$ & 22 & $4,2 \%$ & 67 & $12,6 \%$ & 202 & $38,1 \%$ & 229 & $43,2 \%$ & 4,17 \\
\hline $\begin{array}{l}\text { Busca de } \\
\text { Oportunidades e } \\
\text { Iniciativa }\end{array}$ & 8 & $1,5 \%$ & 28 & $5,3 \%$ & 82 & $15,5 \%$ & 200 & $37,7 \%$ & 212 & $40,0 \%$ & 4,09 \\
\hline $\begin{array}{l}\text { Correr Riscos } \\
\text { Calculados }\end{array}$ & 11 & $4,2 \%$ & 19 & $7,2 \%$ & 43 & $16,2 \%$ & 62 & $23,4 \%$ & 130 & $49,1 \%$ & 4,06 \\
\hline $\begin{array}{l}\text { Estabelecimento de } \\
\text { Metas }\end{array}$ & 3 & $0,4 \%$ & 39 & $4,9 \%$ & 149 & $18,7 \%$ & 344 & $43,3 \%$ & 260 & $32,7 \%$ & 4,03 \\
\hline $\begin{array}{l}\text { Planejamento e } \\
\text { Monitoramento } \\
\text { Sistemático }\end{array}$ & 13 & $2,5 \%$ & 69 & $13,0 \%$ & 110 & $21 \%$ & 190 & $35,8 \%$ & 148 & $27,9 \%$ & 3,74 \\
\hline
\end{tabular}

Fonte: Elaborado pelo autor (2018).

Pode-se observar que, para a amostra de 265 respondentes, de forma auto perceptiva, as três CCEs praticadas com mais intensidade:

- Comprometimento;

- Independência e Autoconfiança;

- Busca de Informações.

No extremo inferior, observa-se:

- Correr Riscos Calculados;

- Estabelecimento de Metas;

- Planejamento e Monitoramento Sistemático.

É importante ressaltar que tal análise não tem efeitos estatísticos, nem pode ser tomada como qualquer tipo de conclusão para efeito de eventuais desdobramentos desse trabalho, mas tem a 
função de ilustrar, a partir das respostas recebidas, como os respondentes se perceberam praticando os comportamentos empreendedores, e com que intensidade os trabalharam.

No processo de seleção para a participação no programa EMPRETEC, os candidatos participam de uma entrevista, na qual é levantada a prática das CCEs, anteriormente ao programa. Embora não haja qualquer conotação estatística na presente análise, o autor levantou, a partir de 10 edições em que participou como facilitador do programa, as CCEs mais praticadas (e as menos praticadas), a fim de fazer um paralelo entre os dados encontrados na pesquisa e aqueles apresentados nas entrevistas de seleção. E foram identificadas as seguintes CCEs como as mais praticadas:

- Persuasão e Rede de Contatos (Não apareceu entre as 3 primeiras na pesquisa quantitativa);

- Persistência (Idem);

- Busca de Informações (Aparece na pesquisa, na mesma posição).

De forma análoga, as 3 menos praticadas:

- Planejamento e Monitoramento Sistemático (Aparece em último na pesquisa);

- Correr Riscos Calculados (Aparece em antepenúltimo);

- Estabelecimento de Metas (Aparece em penúltimo).

Ainda que, do ponto de vista estatístico, nenhuma afirmação ou conclusão possa ser extraída dessas informações, é no mínimo curioso perceber que as mesmas 3 CCEs levantadas nas entrevistas prévias sejam exatamente as mesmas mostradas como as menos praticadas dentro da amostra do presente trabalho. Esse tema será novamente abordado no capítulo seguinte, em que serão apresentadas conclusões e sugestões de trabalhos futuros.

Um dos objetivos secundários desse estudo era verificar a correlação entre a prática das características de comportamento empreendedor, o perfil/momento empreendedor dos participantes, e os resultados alcançados, o que está apresentado a seguir:

Tabela 17 - CCEs por gênero

\begin{tabular}{l|r|r|r}
\hline CCE & Feminino & Masculino & \multicolumn{1}{l}{ Média Geral } \\
\hline Comprometimento & 4,51 & 4,42 & 4,45 \\
\hline
\end{tabular}




\begin{tabular}{l|r|r|r}
\hline Independência e Autoconfiança & 4,41 & 4,33 & 4,36 \\
\hline Busca de Informações & 4,35 & 4,24 & 4,28 \\
\hline Persistência & 4,22 & 4,29 & 4,26 \\
\hline Exigência de Qualidade e Eficiência & 4,27 & 4,16 & 4,20 \\
\hline Persuasão e Rede de Contatos & 4,22 & 4,14 & 4,17 \\
\hline Busca de Oportunidades e Iniciativa & 4,16 & 4,05 & 4,09 \\
\hline Correr Riscos Calculados & 4,09 & 4,05 & 4,06 \\
\hline Estabelecimento de Metas & 3,96 & 4,07 & 4,03 \\
\hline Planejamento e Monitoramento Sistemático & 3,70 & 3,76 & 3,74 \\
\hline
\end{tabular}

Fonte: Elaborado pelo autor (2018).

Embora esse estudo não tivesse como objetivo a análise estatística dos dados obtidos, o autor decidiu fazer uma consulta ao Centro de Estatística Aplicada, do Instituto de Matemática e Estatística da USP, cujo relatório é apresentado como anexo A. Nesse relatório, foi apresentado um teste qui-quadrado, a título de exemplo, para analisar eventuais diferenças nas respostas, em função do gênero dos participantes. E o relatório conclui que não há evidência amostral para diferença entre os gêneros dos entrevistados, de acordo com a distribuição de frequências das respostas.

Gênero foi a única variável analisada do ponto de vista estatístico, tendo em vista que não era objetivo do estudo fazer esse tipo de análise.

Uma análise descritiva desses dados indica não haver diferenças significativas entre a prática dos comportamentos, de acordo com o gênero do participante.

Tabela 18 - CCEs por faixa etária

\begin{tabular}{l|r|r|r|r}
\hline & 25 a 34 anos & 35 a 50 anos & 51 a 65 anos & \multicolumn{1}{c}{ Média Geral } \\
\hline Comprometimento & 4,54 & 4,39 & 4,39 & 4,45 \\
\hline Independência e Autoconfiança & 4,37 & 4,29 & 4,40 & 4,36 \\
\hline Busca de Informações & 4,32 & 4,23 & 4,27 & 4,28 \\
\hline Persistência & 4,28 & 4,24 & 4,29 & 4,26 \\
\hline Exigência de Qualidade e Eficiência & 4,25 & 4,14 & 4,14 & 4,20 \\
\hline Persuasão e Rede de Contatos & 4,28 & 4,24 & 4,29 & 4,17 \\
\hline Busca de Oportunidades e Iniciativa & 4,32 & 3,94 & 3,90 & 4,09 \\
\hline Correr Riscos Calculados & 3,93 & 4,00 & 4,02 & 4,06 \\
\hline Estabelecimento de Metas & 4,10 & 3,89 & 4,07 & 4,03 \\
\hline Planejamento e Monitoramento Sistemático & 3,74 & 3,51 & 3,69 & 3,74 \\
\hline Fon & &
\end{tabular}

Fonte: Elaborado pelo autor (2018). 
Uma análise descritiva mostra que não há indicação de diferença entre as faixas etárias, no que se refere à prática dos comportamentos empreendedores objetos desse estudo.

Tabela 19 - CCEs por grau de escolaridade

\begin{tabular}{l|r|r|r|r}
\hline & \multicolumn{3}{|c}{ Escolaridade } \\
\hline CCE & Até Nível Médio & Superior & Pós-Graduação & Média Geral \\
\hline Comprometimento & 4,38 & 4,25 & 4,25 & 4,45 \\
\hline Independência e Autoconfiança & 4,32 & 4,15 & 4,21 & 4,36 \\
\hline Busca de Informações & 4,14 & 4,14 & 4,16 & 4,28 \\
\hline Persistência & 4,28 & 4,16 & 4,15 & 4,26 \\
\hline Exigência de Qualidade e Eficiência & 4,22 & 4,11 & 4,11 & 4,20 \\
\hline Persuasão e Rede de Contatos & 4,01 & 4,13 & 4,14 & 4,17 \\
\hline Busca de Oportunidades e Iniciativa & 4,11 & 4,09 & 4,06 & 4,09 \\
\hline Correr Riscos Calculados & 3,92 & 4,08 & 4,16 & 4,06 \\
\hline Estabelecimento de Metas & 4,03 & 4,03 & 4,02 & 4,03 \\
\hline Planejamento e Monitoramento Sistemático & 3,82 & 3,93 & 3,89 & 3,74 \\
\hline Fon & & & 4 & \\
\hline
\end{tabular}

Fonte: Elaborado pelo autor (2018).

Igualmente, não se percebe diferença entre os níveis de escolaridade com relação às CCEs.

Tabela 20 - CCEs por tempo de empresa

\begin{tabular}{|c|c|c|c|c|c|}
\hline CCE & $\begin{array}{l}\text { Menos de } 1 \\
\text { ano }\end{array}$ & $\begin{array}{l}1-5 \\
\text { anos }\end{array}$ & \begin{tabular}{|l|}
$6-10$ \\
anos \\
\end{tabular} & $\begin{array}{l}10 \text { anos ou } \\
\text { mais }\end{array}$ & $\begin{array}{l}\text { Média } \\
\text { Geral } \\
\end{array}$ \\
\hline Comprometimento & 4,92 & 4,46 & 4,35 & 4,48 & 4,45 \\
\hline Independência e Autoconfiança & 4,88 & 4,36 & 4,35 & 4,31 & 4,36 \\
\hline Busca de Informações & 4,47 & 4,29 & 4,30 & 4,28 & 4,28 \\
\hline Persistência & 4,75 & 4,29 & 4,27 & 4,17 & 4,26 \\
\hline Exigência de Qualidade e Eficiência & 4,71 & 4,23 & 4,11 & 4,14 & 4,20 \\
\hline Persuasão e Rede de Contatos & 4,79 & 4,22 & 4,04 & 4,12 & 4,17 \\
\hline Busca de Oportunidades e Iniciativa & 4,79 & 4,06 & 4,19 & 4,06 & 4,09 \\
\hline Correr Riscos Calculados & 4,58 & 4,07 & 4,22 & 3,91 & 4,06 \\
\hline Estabelecimento de Metas & 4,56 & 4,03 & 3,98 & 3,99 & 4,03 \\
\hline $\begin{array}{l}\text { Planejamento e Monitoramento } \\
\text { Sistemático }\end{array}$ & 4,00 & 3,76 & 3,76 & 3,64 & 3,74 \\
\hline
\end{tabular}

Fonte: Elaborado pelo autor (2018).

Mais uma vez, não se apresentam diferenças entre a prática de comportamentos empreendedores, no que se refere ao tempo de funcionamento da empresa.

\subsection{Práticas de gestão}


$\mathrm{Na}$ etapa 3 do questionário, foram elaboradas 10 perguntas sobre a gestão dos empreendimentos. O objetivo dessa etapa era avaliar, de forma descritiva, a prática cotidiana dos comportamentos empreendedores através de ações de gestão.

Abaixo estão apresentados os resultados dessa etapa, por CCE.

Tabela 21 - CCE Busca de Informações

\begin{tabular}{|c|c|c|}
\hline Como você consegue conhecimento para seu negócio & Respostas & \\
\hline Fazendo cursos no meu segmento & 164 & $62,6 \%$ \\
\hline Fazendo cursos de gestão & 115 & $43,9 \%$ \\
\hline Indo a Palestras, Workshops, Congressos ou feiras & 176 & $67,2 \%$ \\
\hline Não sei como conseguir conhecimento sobre meu negócio & 0 & $0,0 \%$ \\
\hline Outros & 64 & $24,4 \%$ \\
\hline
\end{tabular}

Fonte: Elaborado pelo autor (2018).

Tabela 22 - CCE Busca de Informações

\begin{tabular}{|c|c|c|}
\hline Para quem você pediu conselho nos últimos 12 meses? & Respostas & \\
\hline Amigos empreendedores & 185 & $70,6 \%$ \\
\hline Outros amigos & 55 & $21,0 \%$ \\
\hline Donos de negócios similares ao meu & 126 & $48,1 \%$ \\
\hline Especialistas, como advogados, contadores, arquitetos, engenheiros, consultores & 146 & $55,7 \%$ \\
\hline Não pedi conselhos a ninguém & 12 & $4,6 \%$ \\
\hline Outros & 15 & $5,7 \%$ \\
\hline
\end{tabular}

Fonte: Elaborado pelo autor (2018).

Tabela 23 - CCE Busca de Informações

\begin{tabular}{l|r|r}
\hline Faz pesquisa de satisfação com seus clientes com que frequência? & \multicolumn{1}{l|}{ Respostas } & \\
\hline Mensalmente & 62 & $23,7 \%$ \\
\hline Bimestralmente & 31 & $11,8 \%$ \\
\hline Semestralmente & 30 & $11,5 \%$ \\
\hline Anualmente & 27 & $10,3 \%$ \\
\hline Não faço pesquisa de satisfação & 110 & $42,0 \%$ \\
\hline
\end{tabular}

Fonte: Elaborado pelo autor (2018).

Essa CCE ficou em terceiro lugar, na etapa 2, entre as mais praticadas. A partir das respostas, é possível, do ponto de vista descritivo, perceber que a prática na gestão das empresas entrevistadas é efetiva, portanto compatível com a autopercepção dos respondentes. Nenhum dos entrevistados respondeu que não sabe como conseguir conhecimento sobre seu negócio, e mais de 60\% dos respondentes obtêm conhecimento através de Palestras, Workshops, Congressos ou feiras, ou ainda participando de cursos em seus segmentos de atuação. Além disso, também pedem conselhos a amigos empreendedores (70\%), e especialistas (55\%). 
Um item que destoou dos demais foi a questão relativa ao levantamento de informações sobre os clientes, na qual $42 \%$ dos entrevistados declararam não realizar pesquisa de satisfação com seus clientes.

Tabela 24 - CCE Busca de Oportunidades e Iniciativa

\begin{tabular}{|c|c|c|}
\hline Você aproveitou oportunidades que surgiram? & Respostas & \\
\hline Sim, no mesmo segmento em que atuo & 202 & $77,1 \%$ \\
\hline Sim, num novo segmento & 59 & $22,5 \%$ \\
\hline Sim, num novo negócio & 32 & $12,2 \%$ \\
\hline Não aproveitei nenhuma oportunidade nos últimos 12 meses & 14 & $5,3 \%$ \\
\hline Outros & 4 & $1,5 \%$ \\
\hline
\end{tabular}

Fonte: Elaborado pelo autor (2018).

Embora apenas 5\% dos entrevistados tenha respondido que não aproveitaram oportunidades nos últimos 12 meses, esta CCE apareceu na pesquisa numa posição inferior, foi apenas a sétima em termos de autopercepção de prática.

Para analisar essa discrepância, ainda que descritivamente, o autor verificou que o comportamento abordado na entrevista que fala sobre a expansão (Questão - Expando/Expandi o negócio ao identificar novos mercados para os produtos ou serviços) teve uma média inferior à média geral de todos os comportamentos, o que pode explicar a diferença.

Tabela 25 - CCE Comprometimento

\begin{tabular}{l|r|r}
\hline Quantas horas você trabalha normalmente por dia? & Respostas & \\
\hline 6 a 8 horas & 84 & $32,1 \%$ \\
\hline 10 a 12 horas & 146 & $55,7 \%$ \\
\hline 14 horas ou mais & 32 & $12,2 \%$ \\
\hline
\end{tabular}

Fonte: Elaborado pelo autor (2018).

Esta CCE foi aquela que os respondentes auto declararam como a mais praticada de todas. Nessa etapa, mais de $67 \%$ dos respondentes afirmaram trabalhar diariamente 10 horas ou mais, o que demonstra uma dedicação aos seus negócios, o que, de forma descritiva, mostra que a prática cotidiana reafirma a autopercepção dos entrevistados.

Tabela 26 - CCE Estabelecimento de Metas

\begin{tabular}{l|r|r}
\hline Como estabeleceu objetivos nos últimos 12 meses? & Respostas & \\
\hline Em função do que o mercado permite & 51 & $19,5 \%$ \\
\hline Por orientação ou imposição de outros, como sócios ou parceiros & 11 & $4,2 \%$ \\
\hline Em função do que eu quero deste negócio & 169 & $64,5 \%$ \\
\hline Não estabeleci objetivos & 25 & $9,5 \%$ \\
\hline
\end{tabular}

Fonte: Elaborado pelo autor (2018). 
Tabela 27 - CCE Estabelecimento de Metas

\begin{tabular}{l|r|r}
\hline Você consegue visualizar o seu negócio daqui a 5 anos, em termos gerais? & Respostas & \\
\hline Sim & 207 & $79,0 \%$ \\
\hline Não & 55 & $21,0 \%$ \\
\hline
\end{tabular}

Fonte: Elaborado pelo autor (2018).

Estabelecimento de metas é uma das CCEs mais importantes para o sucesso de qualquer empreendimento. A partir de metas e objetivos claramente estabelecidos, os empreendedores têm condições de se planejar, mobilizar pessoas e recursos, se dispõem a correr mais riscos, atuam com persistência e comprometimento a fim de alcançar seus resultados.

Descrevendo os resultados dessa CCE na etapa anterior do questionário, pode-se verificar que ela ficou entre as 3 piores, na penúltima posição. Entretanto, quase $2 / 3$ dos respondentes afirmam estabelecer objetivos em função do que querem para o negócio, e 79\% dos entrevistados afirmaram conseguir visualizar o seu negócio daqui a 5 anos.

Uma das principais contradições que podem ser descritas para esta CCE é que a questão da etapa anterior que analisa a visão de futuro do empreendedor (Questão - Tenho uma clara visão de para onde o negócio está indo) teve mais respostas "Usualmente" do que "Sempre", o que pode explicar, ao menos em parte, essa discrepância.

Tabela 28 - CCE Planejamento e Monitoramento Sistemático

\begin{tabular}{l|r|r}
\hline $\begin{array}{l}\text { Com que frequência você levanta informações financeiras sobre seu negócio, } \\
\text { como receitas e despesas, fluxo de caixa, demonstrativo de resultados do } \\
\text { exercício, entre outros? }\end{array}$ & Respostas & \\
\hline Diariamente & 71 & $27,1 \%$ \\
\hline Semanalmente & 81 & $30,9 \%$ \\
\hline Quinzenalmente & 18 & $6,9 \%$ \\
\hline Mensalmente & 71 & $27,1 \%$ \\
\hline Outros & 21 & $8,0 \%$ \\
\hline
\end{tabular}

Fonte: Elaborado pelo autor (2018).

Tabela 29 - CCE Planejamento e Monitoramento Sistemático

\begin{tabular}{l|r|r}
\hline Quais planos de marketing você fez no seu negócio nos últimos 12 meses? & Respostas & \\
\hline E-mail marketing & 85 & $32,4 \%$ \\
\hline Panfletagem & 59 & $22,5 \%$ \\
\hline Publicidade pela Internet & 137 & $52,3 \%$ \\
\hline Redes sociais & 191 & $72,9 \%$ \\
\hline Não fiz planos de marketing ou divulgação & 31 & $11,8 \%$ \\
\hline Outros & 39 & $14,9 \%$ \\
\hline
\end{tabular}

Fonte: Elaborado pelo autor (2018). 
As duas tabelas acima apresentam questões de gestão cotidiana relativas à CCE de Planejamento e Monitoramento Sistemático, a que se mostrou, na análise descritiva apresentada na etapa anterior, como aquela que apresentou os resultados mais fracos.

Tal percepção pode ser descrita também pelas respostas apresentadas na tabela 27 , que diz respeito ao levantamento de informações financeiras sobre o negócio. Apenas $27 \%$ dos respondentes, menos de $1 / 3$ do total, informaram levantar tais informações diariamente. Outros $30 \%$ responderam levantar informações semanalmente, e $27 \%$ ainda informaram obter informações apenas de forma mensal.

Planejamento sem informações atualizadas, especialmente de origem financeira, acaba por não funcionar, o que explica, descritivamente, os fracos resultados apresentados nesta CCE, mesmo na autopercepção pelos respondentes.

Tabela 30 - CCE Persuasão e Rede de Contatos

\begin{tabular}{l|r|r}
\hline Com que frequência você se reúne com sua equipe? & Respostas & $\%$ \\
\hline Diariamente & 62 & $23,7 \%$ \\
\hline Semanalmente & 95 & $36,3 \%$ \\
\hline Quinzenalmente & 20 & $7,6 \%$ \\
\hline Mensalmente & 44 & $16,8 \%$ \\
\hline Outros & 41 & $15,6 \%$ \\
\hline
\end{tabular}

Fonte: Elaborado pelo autor (2018).

Uma maneira importante de se conseguir resultados é influenciando pessoas, e aquelas mais próximas dos empreendedores no seu dia a dia são seus colaboradores, suas equipes de trabalho. A CCE de Persuasão e Rede de Contatos ficou numa colocação intermediária, dentro da descrição feita na etapa anterior. Uma maioria expressiva dos respondentes afirmou se reunir com sua equipe pelo menos uma vez por mês, o que pode ser descrito como compatível com a autopercepção dos participantes levantada na etapa anterior. 


\section{CONCLUSÕES, LIMITAÇÕES E SUGESTÕES PARA PESQUISAS FUTURAS}

O objetivo principal desse trabalho era estudar o impacto do programa EMPRETEC, e sua relação com a prática das 10 características de comportamento empreendedor do programa EMPRETEC, que foi elaborado a partir de detalhada e profunda observação desses comportamentos, e sua posterior catalogação. Tendo sofrido alterações ao longo de seus quase 30 anos de existência, 25 anos presente no Brasil, o autor considerou importante avaliar o real impacto desse programa, após sua última modificação, ocorrida em 2011.

Para isso, era necessário analisar inicialmente teorias comportamentais sobre o empreendedorismo, ou seja, a real influência de comportamentos empreendedores no sucesso daquele que os praticavam, posteriormente analisar aspectos pertinentes à Educação Empreendedora, visto que o problema de pesquisa estava baseado no estudo de um programa de treinamento comportamental para empreendedores, e por último avaliar o impacto de programas de educação empreendedora, ou seja, estabelecer instrumentos que pudessem de fato avaliar o resultado desses programas e sua contribuição para os empreendedores.

É importante ressaltar que a base do programa EMPRETEC, conforme já apresentado, é comportamental, portanto relativamente intangível. Com base nesse contexto, os resultados apresentados foram analisados de forma descritiva.

Dois pontos são importantes na conclusão desse estudo: a prática efetiva dos comportamentos empreendedores, seja na autopercepção dos respondentes, seja numa confrontação com práticas de gestão que pudessem indicar a real prática, e o impacto desses comportamentos nos resultados dos empreendimentos daqueles que participaram do programa EMPRETEC.

$\mathrm{Na}$ questão da prática efetiva dos comportamentos, é possível estabelecer as seguintes conclusões:

- Os respondentes parecem ter colocado em prática os comportamentos empreendedores preconizados pelo programa EMPRETEC. Essa conclusão tem como base os indicadores de média ponderada, moda e mediana, que apresentam números significativos, além da confrontação de práticas de gestão que, em sua maioria, atestam a prática efetiva dos comportamentos, traduzidos na forma de ações cotidianas. 
- Foi possível identificar como CCEs mais praticadas: Comprometimento, Independência e Autoconfiança, e Busca de Informações, e as menos praticadas, como Correr Riscos Calculados, Estabelecimento de Metas e Planejamento e Monitoramento Sistemático.

- Foi igualmente possível perceber algumas discrepâncias entre as autopercepções e as práticas de gestão, em especial com as CCEs de Estabelecimento de Metas e de Busca de Oportunidades e Iniciativa. Embora se auto avaliem de uma forma positiva na prática dessas CCEs, os respondentes não mostraram práticas de gestão condizentes com essa suposta prática.

- Da mesma forma, as práticas de gestão serviram para ratificar as CCEs de Comprometimento e Busca de Informações, que figuraram entre as mais praticadas, e a CCE de Planejamento e Monitoramento Sistemático, que ficou em último lugar. Ao contrário do item anterior, aqui os respondentes se auto avaliaram positivamente, quanto à prática dessas CCEs, e mostraram, através da gestão, a efetiva prática das mesmas.

Um ponto importante nessa conclusão está no debate entre comportamentos versus ferramentas. Trazendo conceitos do CHA, conhecimento, habilidade e atitudes, pode-se avaliar que conhecimentos e habilidades seriam as ferramentas do empreendedor, e as atitudes, os comportamentos empreendedores. Por vezes essa questão é tratada como um conflito, quando a melhor abordagem seria analisar esses dois instrumentos como complementares, ou seja, empreendedores sem conhecimento e habilidade (ferramentas), mas com atitude (comportamentos), provavelmente terão dificuldade em atingir seus resultados.

E isso parece ficar bastante evidente quando se trata de Estabelecimento de Metas e de Planejamento e Monitoramento Sistemático. Sem o auxílio de ferramentas, a prática dessas CCEs fica prejudicada, pois pode terminar sem referências, ou seja, os empreendedores até desejam praticá-las, mas não sabem exatamente como fazer.

Como conclusão nesse aspecto, é importante destacar a necessidade de ações pós EMPRETEC, que permitam aos participantes colocar em prática, de forma ordenada e estrutura, essas duas CCEs que são extremamente importantes na obtenção de resultados, uma vez que uma ( Estabelecimento de Metas) orienta os empreendedores a saber onde querem chegar, e a outra (Planejamento e Monitoramento Sistemático), a identificar os caminhos necessários para alcançar o destino, os resultados dos seus empreendimentos. 
Não à toa, essas duas CCEs ficaram nas últimas posições, entre as menos praticadas. Cabe ao Sebrae, como instituição responsável pelo programa no Brasil, acompanhar os participantes, e desenvolver programas e/ou ferramentas que os permitam efetivamente praticar os comportamentos empreendedores, em particular aqueles nos quais os participantes apresentam as maiores dificuldades.

Igualmente, empreendedores sem atitudes (comportamentos) mas com conhecimento e habilidades (ferramentas), não saberão o que fazer com essas ferramentas, e apresentarão dificuldades em alcançar os resultados. A combinação entre conhecimento, habilidades (ferramentas) e atitudes (comportamentos) parece ser um fator determinante para o sucesso dos empreendimentos.

Ainda no tema dos comportamentos empreendedores, um dos objetivos secundários desse estudo era verificar a correlação entre a prática das características de comportamento empreendedor e o perfil/momento empreendedor dos participantes.

Foi feita uma análise estatística em relação aos comportamentos de acordo com o gênero dos respondentes, e análises descritivas para faixa etária, tempo do empreendimento e grau de escolaridade. Não foi possível perceber nenhuma diferença significativa na prática dos comportamentos, de acordo com essas análises.

Uma segunda questão importante era avaliar os impactos nos resultados dos empreendimentos daqueles que participaram do programa EMPRETEC. Embora a resposta a essa questão tenha ficado relativamente prejudicada por limitações que serão apresentadas no capítulo seguinte, é possível perceber um impacto positivo nos empreendimentos dos participantes, a partir de um indicador indireto, o número de funcionários que as empresas tinham antes e depois de participar do EMPRETEC.

Retomando o que foi apresentado na análise dos resultados, o número de empresas sem funcionários caiu de $30 \%$ para $8 \%$, um dado bastante significativo, o que fez crescer o número de empresas de 1 a 5 funcionários, de $43 \%$ para $51 \%$ do universo dos respondentes, e mesmo empresas com um número maior de funcionários, entre 6 e 10, e entre 11 e 20 , tiveram seus percentuais aumentados de $9 \%$ para $19 \%$, e de $6 \%$ para $11 \%$, respectivamente. 
Se os empreendedores contrataram pessoas após sua participação no EMPRETEC, é sinal de que houve um desenvolvimento efetivo dos seus empreendimentos. Até mesmo se os dados estivessem se mantido estáveis nas análises pré e pós EMPRETEC, um eventual aumento de produtividade poderia gerar melhores resultados com a mesma quantidade de funcionários. $\mathrm{O}$ aumento em quase todos os extratos analisados nos leva a concluir que os impactos da prática dos comportamentos empreendedores preconizados no EMPRETEC foram bastante positivos para seus participantes, e seus empreendimentos.

Essas análises servem como base para ratificar, justificar e embasar a conclusão em relação à última pergunta do questionário, que_indagava aos respondentes se o programa EMPRETEC havia feito diferença em sua jornada empreendedora. Das 265 respostas consideradas válidas pelos filtros da pesquisa, 95\% foram respostas "sim", ou seja, que o EMPRETEC havia feito diferenças para os seus participantes.

O altíssimo percentual de respostas positivas (95\%) se mostra compatível com os dados apresentados pelo Sebrae, no qual os participantes deram nota 9,1 (de um total de 10), e indica claramente a força que esse programa de formação de empreendedores tem. Num momento em que se fala cada vez mais sobre empreendedorismo, como apresentado no capítulo inicial, é importante considerar a relevância e o papel cada vez mais preponderante e protagonista que a Educação Empreendedora como um todo deve ter nos dias de hoje.

O EMPRETEC é talvez o programa mais icônico em Educação Empreendedora, e seus resultados em 25 anos de existência no Brasil, apresentados através de muitos estudos e estatísticas do próprio Sebrae, atestam que o caminho, irreversível, num mundo que cada vez mais fala em Empreendedorismo, é educar os empreendedores e candidatos a empreendedores, para que consigam alcançar resultados relevantes e duradouros, contribuindo assim para o desenvolvimento do país.

\subsection{Limitações}

Uma das maiores limitações desse estudo foi o acesso aos participantes do programa EMPRETEC no estado de São Paulo. O autor solicitou através de mensagem de e-mail para a Coordenação Estadual do programa EMPRETEC no estado de São Paulo (Sebrae) o envio do link do questionário eletrônico para os participantes do EMPRETEC no estado de São Paulo 
que tivessem participado do programa a partir de 2012. Levando em consideração uma média de 150 edições do EMPRETEC realizadas em média por ano (dados extraoficiais obtidos pelo autor), com 25 participantes, em média, por edição, seriam quase 20 mil participantes de 2012 a 2016. Esse número é cerca de 15 vezes maior que o banco de dados que o autor conseguiu reunir, através de diferentes fontes

Em função disso, a amostra dos respondentes foi feita por conveniência, e muitos dos respondentes haviam participado do programa tendo o autor como um dos facilitadores da equipe, o que pode ter gerado um viés nas respostas, além de representar uma amostra cerca de 15 vezes menor que o número aproximado de participantes dentro do recorte da pesquisa, o que faz com que os resultados e conclusões não possam ser extrapolados para a população dos participantes do programa EMPRETEC no estado de São Paulo.

Outro fator limitante, em função do tempo disponível para a realização da pesquisa, e da não possibilidade de acesso aos dados de participantes, foi não ter sido possível fazer um levantamento anterior à participação no programa, para fins de comparação com os resultados apresentados após essa participação.

Uma outra limitação identificada pelo autor está no fato de que a prática das CCEs foi levantada a partir da autopercepção dos participantes, e não por um instrumento mais direto que pudesse acompanhar a efetiva e real prática auto percebida pelos respondentes.

Também não foi possível apresentar instrumentos que pudessem tangibilizar a efetiva prática dos comportamentos empreendedores, e os resultados da prática das CCEs, ou seja, como isso pode favorecer o empreendedor e alavancar seu sucesso.

\subsection{Sugestões para pesquisas futuras}

Um trabalho bastante importante sobre esse tema foi apresentado por Lopes (1999), que, em sua dissertação de Mestrado, apresentou um estudo feito com 64 participantes, através de um estudo longitudinal, comparando indicadores pré e pós participação no programa EMPRETEC.

Tal estudo, porém, foi feito antes da última modificação do programa. Fica a sugestão para a realização de estudo semelhante, ou seja, coletando informações antes e depois da participação no EMPRETEC, em relação ao seu atual formato, de 6 dias. Para isso, entretanto, o 
envolvimento, participação e autorização do Sebrae são fundamentais, sem os quais não será possível alcançar tais objetivos.

Além disso, um dos pontos observado inicialmente foi a questão de empreender por necessidade versus oportunidade. Uma sugestão seria formular uma pergunta específica sobre esse ponto nos questionários, e posteriormente analisar resultados em separado, para saber se há diferenças significativas entre esses grupos.

Uma outra sugestão é encontrar maneiras de fazer um estudo que permita analisar os resultados dos empreendimentos dos participantes, para identificar como a prática das CCEs pode alavancar o sucesso desses empreendedores.

Por fim, e de forma a garantir uma maior imparcialidade na análise do programa EMPRETEC, o autor sugere a realização de estudos por iniciativa de pesquisadores menos envolvidos com o programa, a fim de gerar um distanciamento muitas vezes necessário para uma melhor estruturação da pesquisa, bem como na análise dos resultados. 


\section{REFERÊNCIAS}

ALVIM, Silvana. Impacto em profundidade e amplitude: Avaliando um treinamento extra organizacional com foco em empreendedorismo. 2008. Dissertação (Mestrado em Psicologia) - Universidade Federal da Bahia (UFBA), Salvador, 2008.

BARLACH, Lisete. A criatividade humana sob a ótica do empreendedorismo inovador. 2009. Tese (Doutorado em Psicologia) - Universidade de São Paulo (USP). São Paulo, 2009.

BROWN, Travor C; HANLON, Dennis. Developing behavioural observation scales to foster effective entrepreneurship. Journal of Small Business and Entrepreneurship. v.17, n.2, 2004.

BROWN, Travor C; HANLON, Dennis. Behavioral Criteria for Grounding Entrepreneurship Education and Training Programs: A Validation Study. Journal of Small Business

Management, v. 54, n. 2, p. 399-419, 2016.

DALFOVO, Michael S.; LANA, Rogério A.; SILVEIRA, A. Métodos quantitativos e qualitativos: Um resgate teórico. Revista Interdisciplinar Científica Aplicada, v. 2, n. 4, p. 01-13, 2008.

ELMUTI, Dean; KHOURY, Grace; OMRAN, Omar. Does entrepreneurship education have a role in developing entrepreneurial skills and ventures'efectiveness? Journal of

Entrepreneurship education, v. 15, p. 83-98, 2012.

EMPRETEC. Inspiring entrepreneurship. Disponível em:

$<$ http://empretec.unctad.org/?page_id=18 . Acesso em: 15/09/2016

EMPRETEC. Annual Report, 2014.

ERNST \& YOUNG. Nature or Nurture. Decoding the DNA of the Entrepreneur. 2011.

FISCHER, Tânia. Mestrado Profissional como Prática Acadêmica. Revista Brasileira de Pós-Graduação, v. 2, n. 4, pp. 24-29, 2005.

FLANAGAN, Patrick. Successful entrepreneurs carry a personality trait that displays the psychological characteristics of internal locus of control, high self-esteem, propensity to take risks, tolerance of ambiguity, need for achievement and innovativeness. 2014.

Dissertação (Mestrado em Administração) - National College of Ireland, 2014.

FLICK, Uwe. Introdução à Pesquisa Qualitativa. São Paulo: Artmed, 2009.

FRANCESCONI, Milton. Centro de Serviços Compartilhados para Pequenas Empresas: avaliação de uma iniciativa empreendedora de prestação de serviços. 2016. Dissertação (Mestrado Profissional em Empreendedorismo). FEA-USP, São Paulo, 2016.

FREDERICK, Howard H. Blended Learning in Entrepreneurship Education in the Asia-Pacific: A Grounded Theory Approach to Entrepreneurship Pedagogy. AUSTRALIA NEW ZEALAND ASSOCIATION OF MANAGEMENT, STREAM 7. Sydney, Australia, 2007. 
FREITAS, Henrique; OLIVEIRA, Mírian; SACCOL, Alessandra Z; MOSCAROLA, Jean. O Método de Pesquisa Survey. Revista de Administração. v. 35, n. 3, pp. 105-112. 2000.

GIL, Antônio C. Como Elaborar Projetos de Pesquisa. São Paulo. 2002.

GLOBAL ENTREPRENEURSHIP MONITOR. Empreendedorismo no Brasil, 2015.

GLOBAL ENTREPRENEURSHIP MONITOR. Empreendedorismo no Brasil, 2016.

GORMAN, Gary; HANLON, Denis; KING, Wayne. Some Research Perspectives on Entrepreneurship Education, Entrerprise Education and Education for Small Business Management: A Ten-year Literature Review. International Journal of Small Business, v. 15, n. 3, 1997.

INSTITUTO BRASILEIRO DE GEOGRAFIA E ESTATÍSTICA. Demografia das Empresas. Brasília, 2017.

JONATHAN, Eva; SILVA, Taissa. Empreendedorismo feminino: tecendo a trama de demandas conflitantes. Psicologia \& Sociedade. v. 19, pp 77-84, 2007.

KAUFMANN, Patrick; WELSH, Dianne; BUSHMARIN, Nicholas. Locus of Control And Entrepreneurship in The Russian Republic. Entrepreneurship Theory and Practice, v. 20, n. 1, p 43-56, 1995.

KLEIN, Peter; BULLOCK, J Bruce. Can Entrepreneurship Be Taught? Journal of Agricultural and Applied Economics. v. 38, n. 2, p.429-439, 2006.

KRAKAUER, Patrícia V C; MARQUES, Jane A; ALMEIDA, Martinho I R. Mestrado Profissional em Administração: Diretrizes na elaboração de projetos. In: ENCONTRO ENANPAD, Belo Horizonte-MG, 2015.

KURATKO, Donald F. Entrepreneurship Education: Emerging Trends and Challenges for the 21st Century. White Paper, U. S. Association of Small Business Education, 2003.

KUZON. William; URBANCHECK, Melanie; McCABE, Steven. The seven deadly sins of statistical analysis. Annals of Plastic Surgery. v .37, p. 265-272, 1996.

KYNDT, Eva; BAERT, Herman. Entrepreneurial Competencies: Assessment and predictive value for entrepreneurship. Journal of Vocation Behavior, v. 90, p. 13-25, 2015.

LATHAM, Gary; WEXLEY, Kenneth. Behavioural Observation Scales For Performance Appraisal Purposes. Personal Psychology, v. 30, p. 255-268, 1977.

LENZI, Fernando Cesar; VENTURI, James Luiz; DUTRA, Ivan de Souza. Estudo Comparativo das Características e Tipos de Empreendedores em Pequenas Empresas, In: ENCONTRO ENANPAD, Camboriú-SC, 2005.

LEVENSON, Hanna. Distinctions within the concept of internal-external control: Development of a new scale. Proceedings of the Annual Convention of the American Psychological Association. v. 7, n. 1, p. 261-262, 1972. 
LIMA, Telma C. S.; MIOTO, Regina C. T. Procedimentos metodológicos na construção do conhecimento científico: A pesquisa bibliográfica. Revista Katál, v. 10, n. esp, p. 37-45. Florianopólis, 2007.

LOPES, Rosemary. Avaliação de Resultados de um Programa de Treinamento Comportamental para Empreendedores - EMPRETEC. 1999. Dissertação (Mestrado em Psicologia) - Instituto de Psicologia, USP, São Paulo, 1999.

LUNA, Sergio Vasconcelos de. Planejamento de pesquisa: uma introdução. São Paulo. EDUC. 1997.

MACIEL, Cristiano de O; CAMARGO, Camila. Lócus De Controle, Comportamento Empreendedor e Desempenho De Pequenas Empresas. RAM - Revista De Administração Mackenzie, v. 11, n. 2. 2010.

MCCLELLAND, David.et al. The Achievement motive. Boston: Irvington, 1967.

MCCLELLAND, David. Entrepreneurs are Made, Not Born. Forbes, v. 103, n. 11, p. 53-54, 1969.

MCCLELLAND, David et al. Talent and Society. Nova Iorque: Van Nostrand, 1958.

MIRON, David; MCCLELLAND, David C. The Impact of Achievement Motivation Training on Small Businesses. California Management Review. v. 21, n. 4, p 13-28, 1979.

MORALES, Sandro. Relação entre competências e tipos psicológicos Junguianos entre empreendedores. 2004. Tese (Doutorado em Engenharia de Produção). Universidade Federal de Santa Catarina (UFSC), Florianopólis, 2004.

MOREIRA TAVARES, Carlos E.; LUIZ DE MOURA, Gilnei; NUNES ALVES, Juliano. Educação empreendedora e a geração de novos negócios. Observatorio de la Economía Latinoamericana, v. 188, 2013.

NICOLACI-DA-COSTA, Ana Maria. O Campo da Pesquisa Qualitativa e o Método de Explicitação do Discurso Subjacente (MEDS). Psicologia: Reflexão e Crítica. v. 20 (1), pp. 65- 73. 2007.

NORMAN, Geoff. Likert Scales, Levels of Measurement, and the "Laws" of Statistics. Advances in Health Science Education, 2010.

O'CALLAGHAN, Ramon. Educating Entrepreneurs: Process, Outcomes and the Experience at Nazarbayev University. In: International Conference on Entrepreneurship and Business Education in Emerging World International Academy of Business. Cazaquistão, 2013.

OLIVEIRA, João Maria. Empreendedor Individual: Ampliação da Base Formal ou Substituição do Emprego? Radar. n. 25, 2013.

PAULINO, Alice Dias; ROSSI, Sonia Maria Morro. Um estudo de caso sobre Perfil Empreendedor - Características e traços de personalidade empreendedora. EGEPE ENCONTRO DE ESTUDOS SOBRE EMPREENDEDORISMO E GESTÃO DE PEQUENAS EMPRESAS. Brasília, 2003. 
PILATI, Ronaldo; ABBAD, Gardênia. Análise Fatorial Confirmatória da Escala de Impacto do Treinamento no Trabalho. Psicologia: Teoria e Pesquisa. v. 21 n. 1, p. 43-51. 2005.

POLITIS, Diamanto.The Process of Entrepreneurial Learning: A Conceptual Framework, Entrepreneurship Theory and Practice, v. 29. n. 4, p. 399-424, 2005.

REIS, Isaílton S. Comportamentos empreendedores na gestão de pequenas empresas. 2013. Dissertação (Mestrado em Gestão) - Universidade De Trás-os-Montes e Alto Douro, Portugal, 2013.

RIBEIRO, Renato J. Mestrado Profissional, Mestrado Acadêmico e Doutorado. Brasília, 2007.

ROTTER, Julian B. Generalized expectancies for internal versus external control of reinforcement. University of Connecticut. v. 80, n. 1, 1966.

SCHUMPETER, Joseph. Change and the Entrepreneur: Postulates and Patterns for Entrepreneurial History. Boston: Harvard University Press, 1949.

SEBRAE. Título do artigo. Disponível em:

$<$ http://www.sebrae.com.br/sites/PortalSebrae/sebraeaz/EMPRETEC:-fortale\%C3\%A7a-suashabilidades-como-empreendedor>._Acesso em: 14 nov. 2017.

SEBRAE - Disponível em:

$<$ http://www.sebrae.com.br/sites/PortalSebrae/canais_adicionais/conheca_quemsomos $>$.

Acesso em: 14 jan. 2018.

SEBRAE-SP. Manual do Facilitador EMPRETEC, Brasília, 2010.

SEBRAE - Unidade de Gestão Estratégica. Participação das micro e pequenas empresas na economia brasileira. Brasília, 2014.

SEBRAE - DIEESE. Anuário do trabalho nos pequenos negócios. São Paulo, 2017.

SILVA, Edna L; MENEZES, Estera M. Metodologia de pesquisa e elaboração de dissertação. UFSC, 2005.

VALE, Gláucia M. V. Empreendedor: Origens, Concepções Teóricas, Dispersão e Integração. RAC, v. 18, n. 6, p. 874-891, Rio de Janeiro, 2014.

VIEIRA, Henrique C; CASTRO, Aline E; SCHUCH Jr. Vitor F. O uso de questionários via email em pesquisas acadêmicas sob a ótica dos respondentes. XIII SEMEAD - Seminários em Administração, 2010. 
APÊNDICE A - Formulário da Pesquisa Qualitativa

Introdurtio

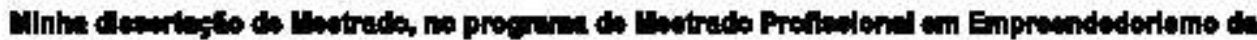

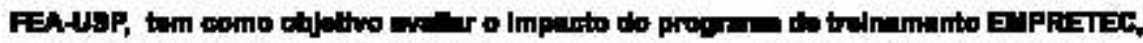

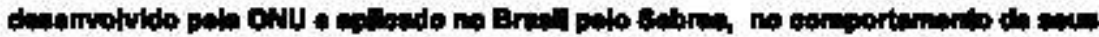

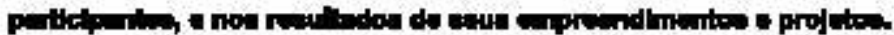

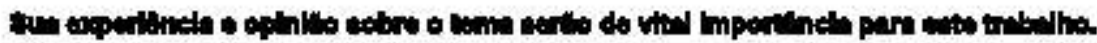

1. Nome

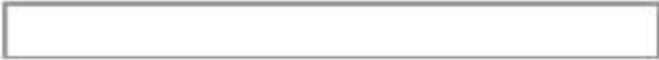

2 Formatiosio

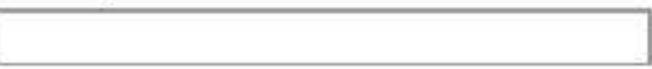

3. Reivelo enm o emproendadortemo

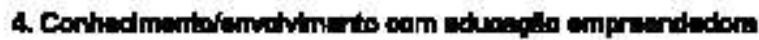

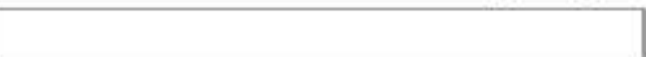

6. Conhadmentofenvilytme to cam a progema EMPRETEC 
Questlontivo

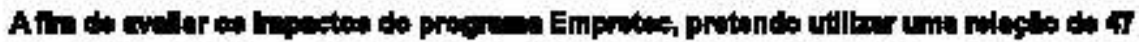

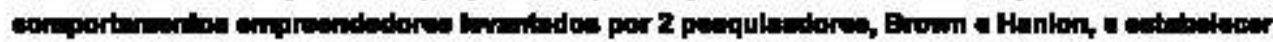

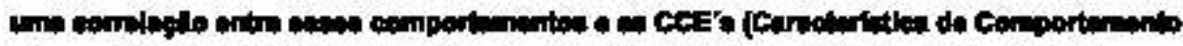

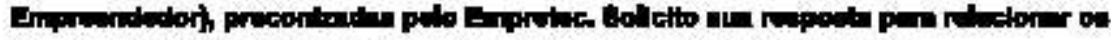

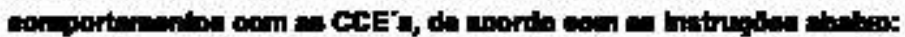

a Thoul das CCEE'

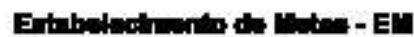

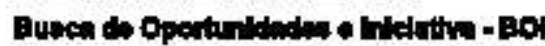

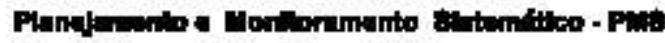

Comar Flabe: Celouleda - Cac

Duect do Infermestow - $\mathrm{E}$

Erighnala do Qudidada o Erathida - Ex:E

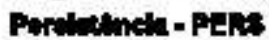

Comprometmanta - Goup

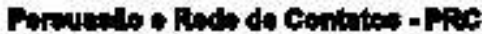

Ldependincta s Autocosilinnga - LAt

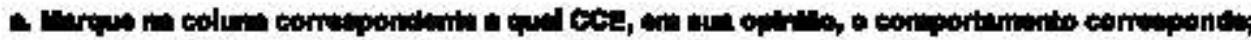

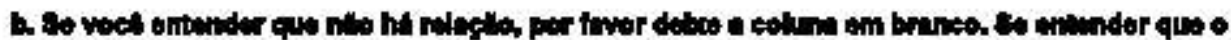

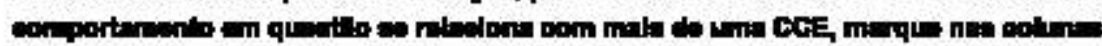
cermependentien:

B. Tabela de comportenentos pere preenchimento

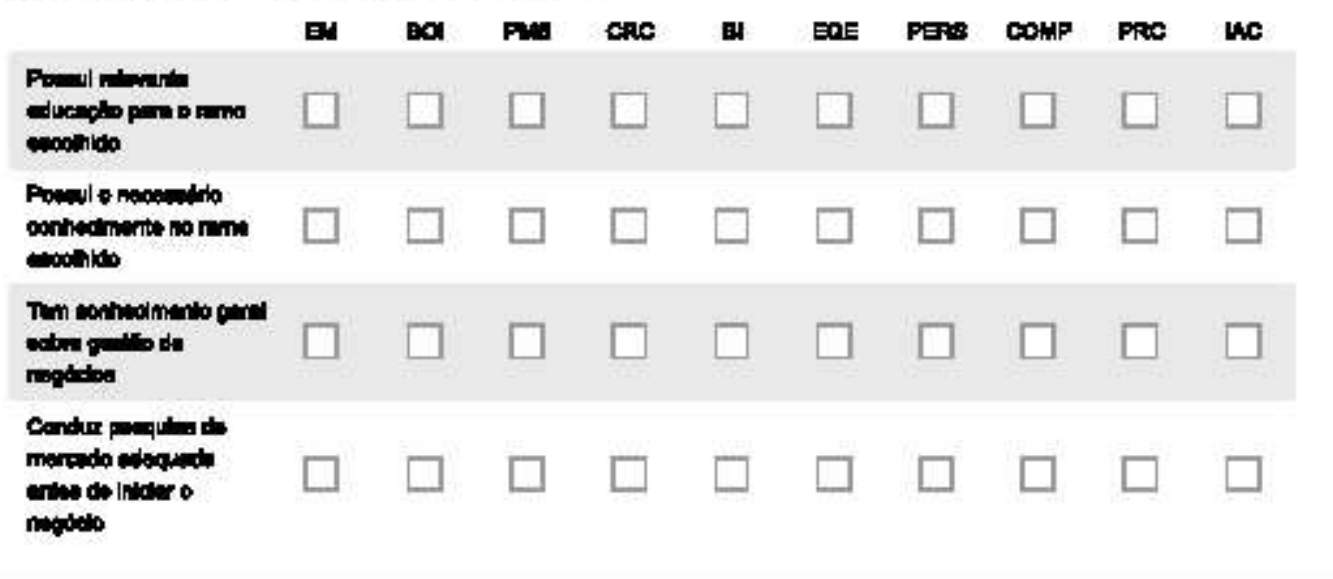




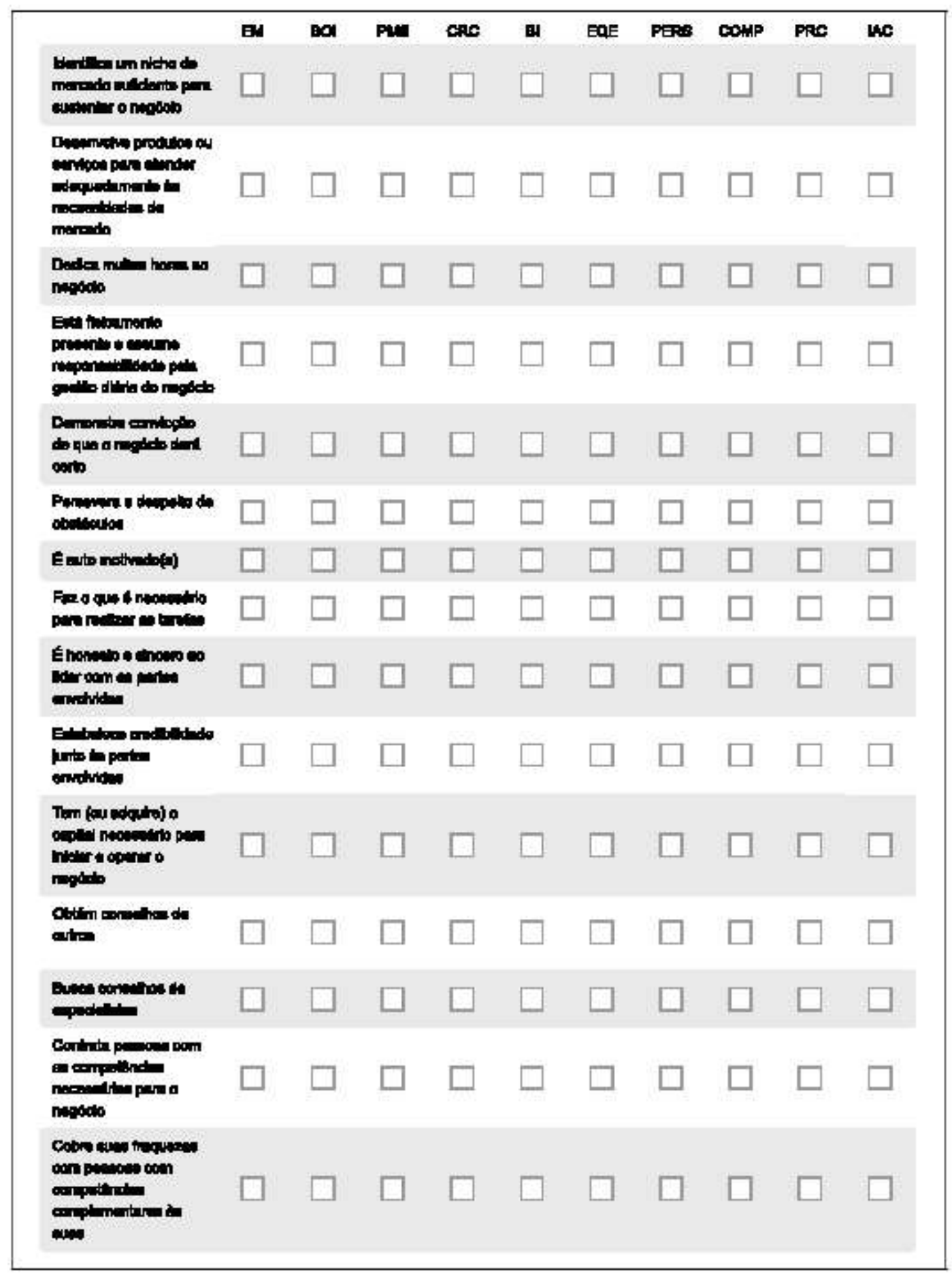




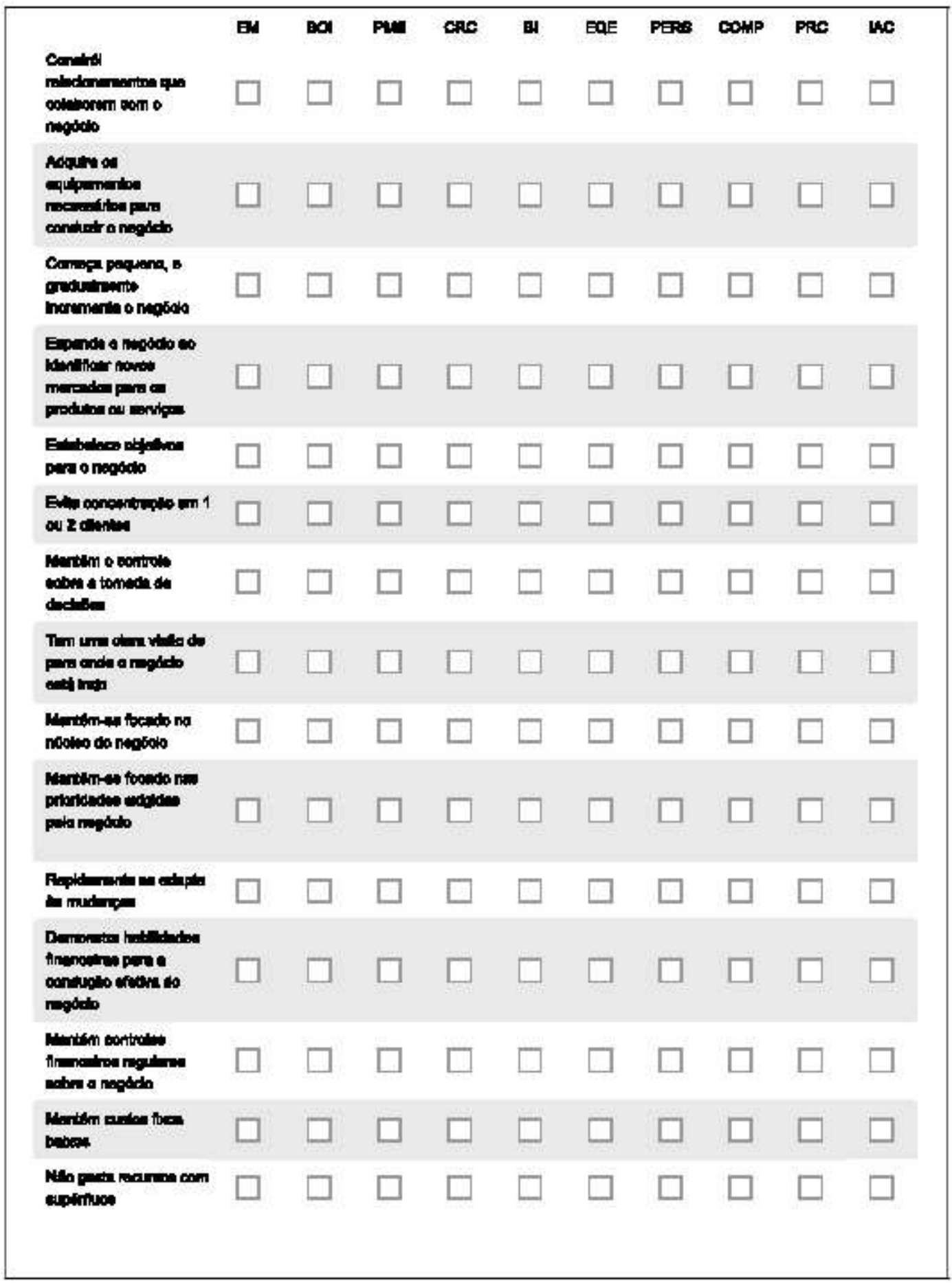




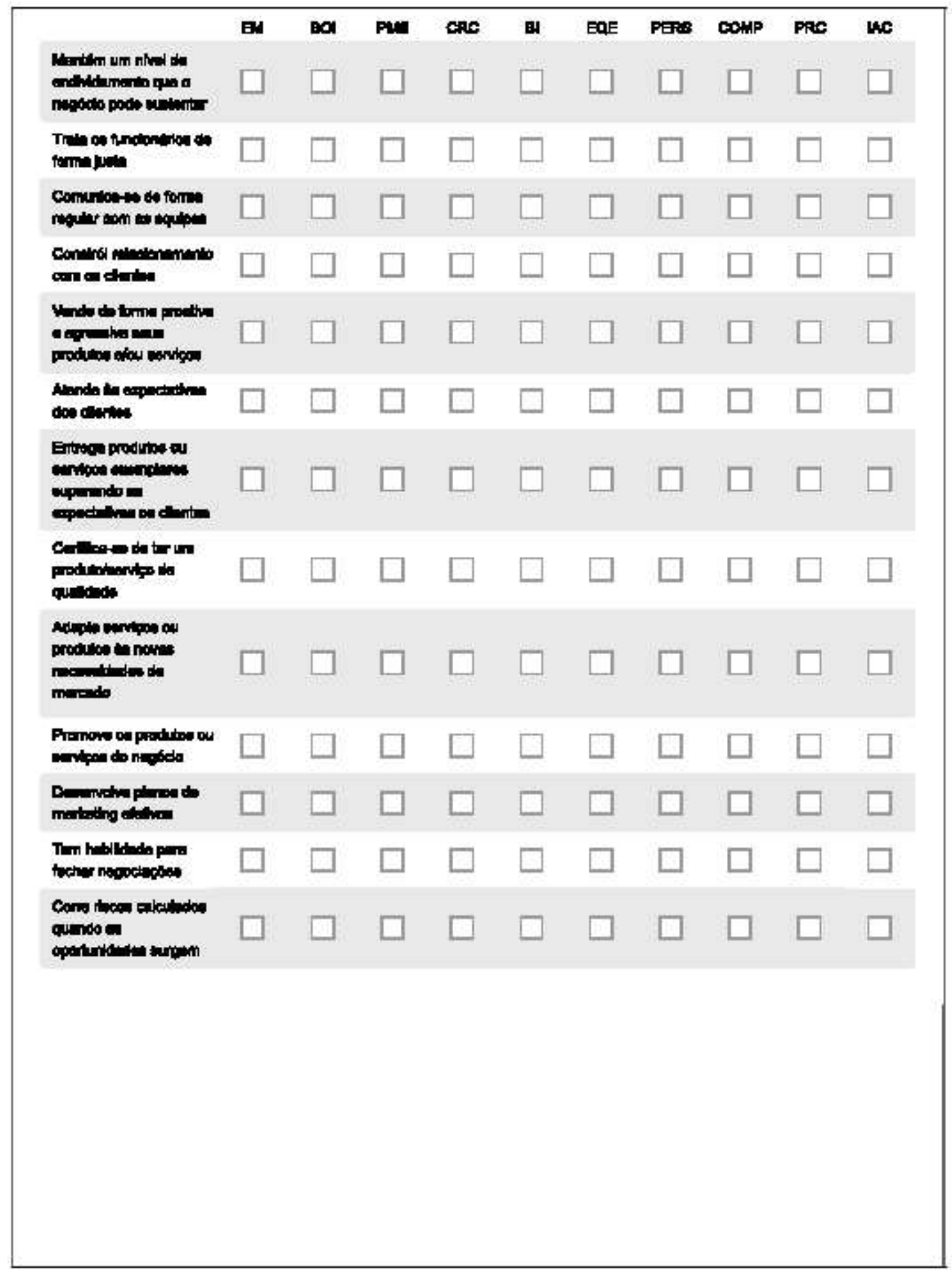


Conchuatio

Aqredego au pertedpaplo.

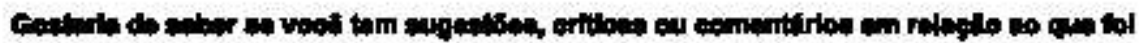

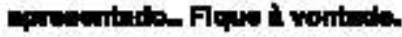

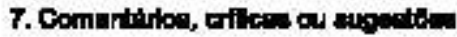


APÊNDICE B - Formulário Pesquisa Quantitativa

20त्रा?

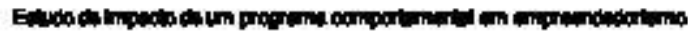

\section{Estudo de impacto de um programa comportamental om empreendedorismo}

Introdurlo

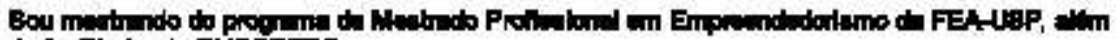
de fachinder do EUPRETEC.

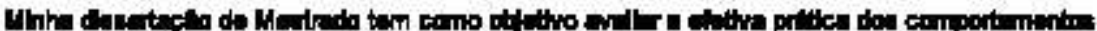

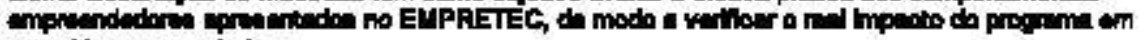

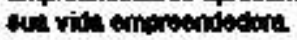

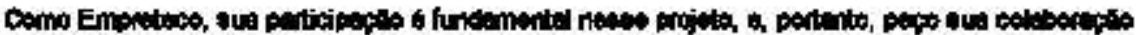
no prenchimerto dect peaquall

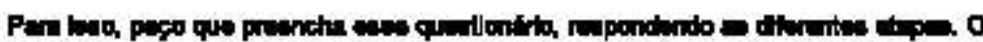

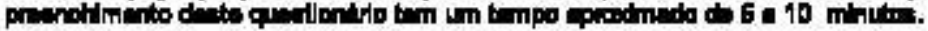

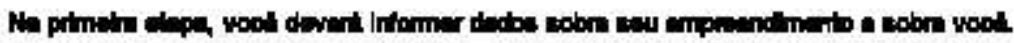

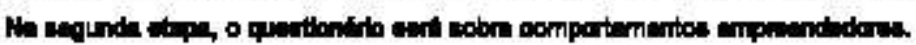

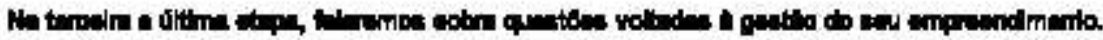

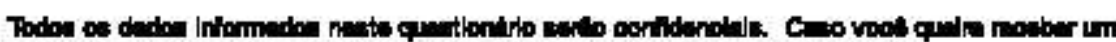

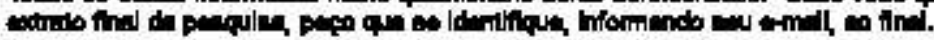

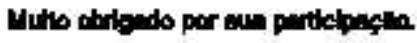

Ful Tame

Obulgandrio

\section{Etapa 1 - Dados da empreana e do(a) empreondedor(a)}

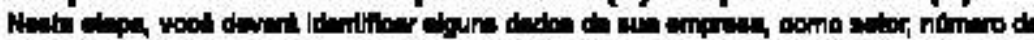

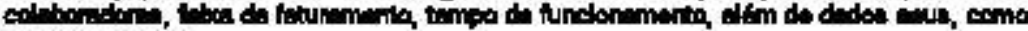
omproondodonty.

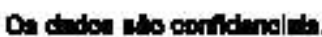

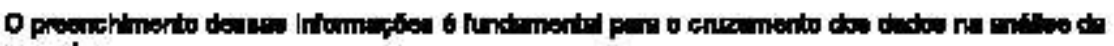
paratie

1. Qundo weat fire o Empotes?

hrear apenes ume ovid.

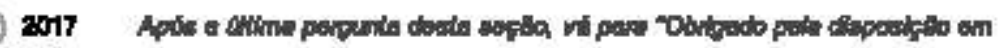
partialer:

2010

(D) 2015

(D) 2014

2013

2012

2011

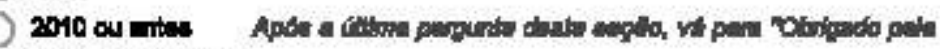
cheorigos am perteper: 


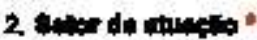

Mower apone ime ovel

Camirito

Benripe

Indistita

Gutro:

2. Himno de eolabordore -Ambe do Emprates

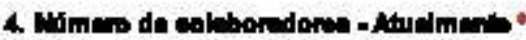

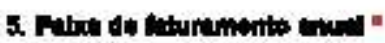

Mherar epanes ume ond.

Ab Ra cand,

De RA 60,000,00 a R- 30,000,00

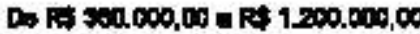

Do fit 1200.000,00 = Ft 2,000,000,00

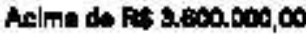

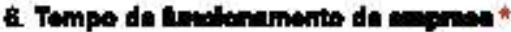

\section{Dendoed do[a) Emprecendedor(a)}

7. Aas

Mincer apando ima oved.

Fomining

C) Mrenolno

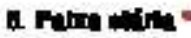

Ampar apenes ume ond
$18 \square 24=10$
$2034=10$
36 $100=10$
51 a B inta
Anpind do 65 ane 


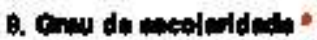

Nowar apones ume ovel.

Enaino fundmente

Emino Modo

(D) superor

Paspoduefio

\section{Etapa 2 - Comportamentos Empreendedores}

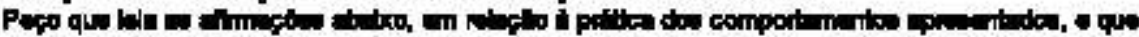

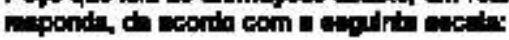

1. Nunea

2 Pinmon

8. Al varim

4. Unialmente

5. vompen

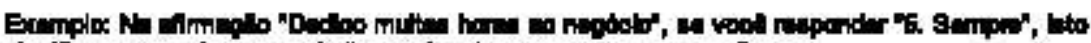

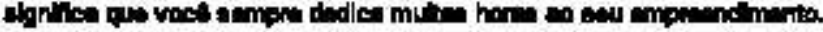

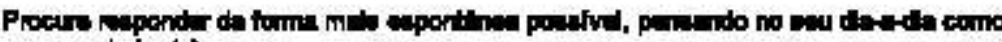
empinendeder (A3. 
1h.

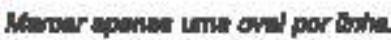

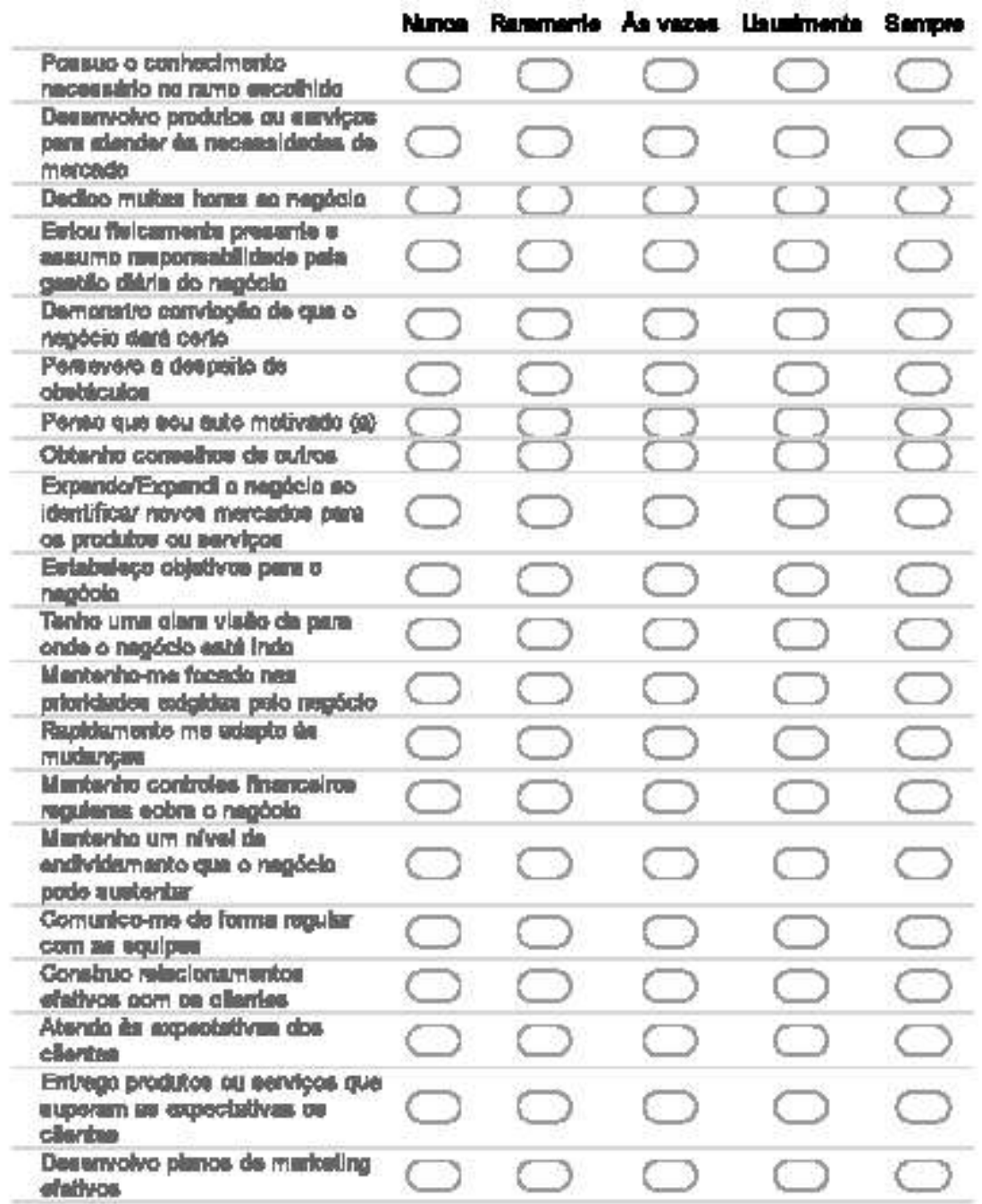

\section{Etapa 3 - Pritleas do gestllo}

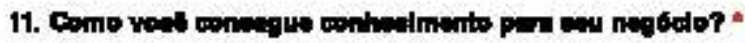
Mapie bodur que as molonem.

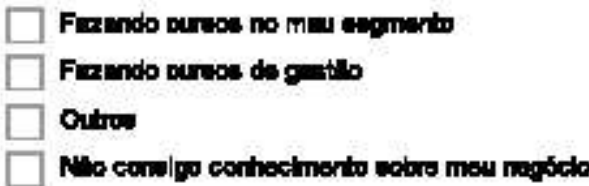




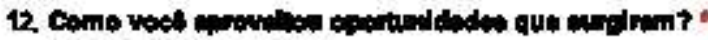

Manor aponie umi ovid.

No masmo asomerto en que tho

C Num nowo alomente

Dim nowo nepole

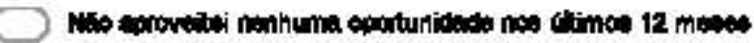

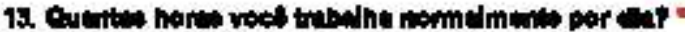

Meper openes ums ovel.

Bathore

10.12 how

14 how ou mit

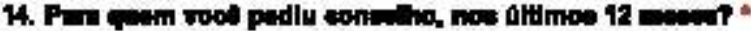
Marcar apenes ume ovel

Dimlan emponendeders

\section{Othou entro:}

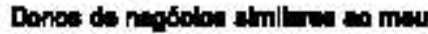

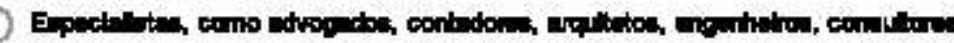

Wo pedl fonmehos a ninguim

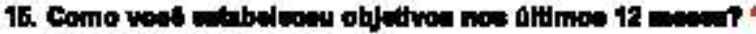
Monar apmes unt ovel.

Em funqle da que a mecodo permita

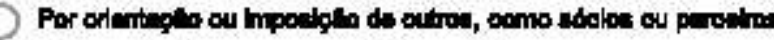

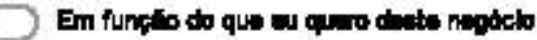

(1) No whelecl dithos

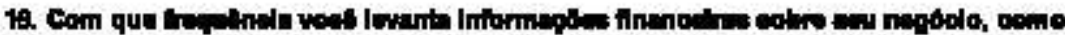

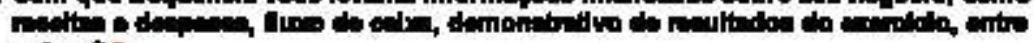
comeat "

Mrovar apenus uma ond.

Darmant

Deminadmonto

Culruminents

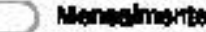

Ourr:

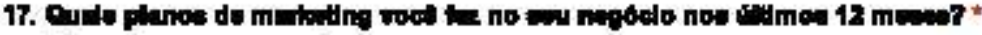
Moner aponse ume ove.

E-mill marketing

Partitutiogm

Publektudo pela Intomat

Rocke rochls:

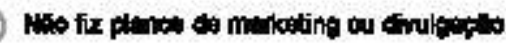




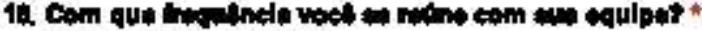

Monar aponie imi ovid.

Dlarmenta

Comidmonto

Cudranemento

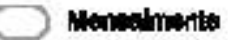

curv:

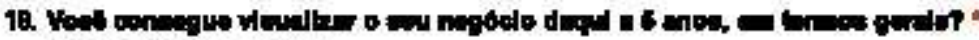
Memar apones imi ovid.

$\bigcirc \mathrm{sm}$

№so

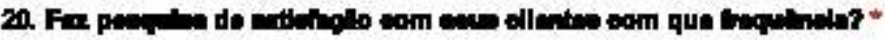

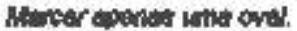

(D) Mnomentita

(B) Bmandmento

Semendmento

D Anvinimerta

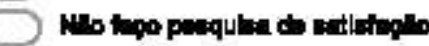

Obrigado por sua particlpacilo

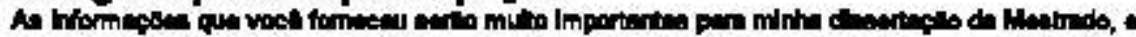
poderbo aluter fituros empisendectrise

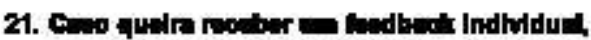

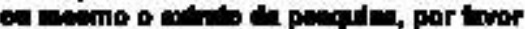

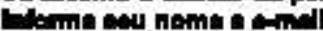

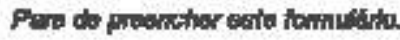

Obrigado pela diaposifflo em partieipar

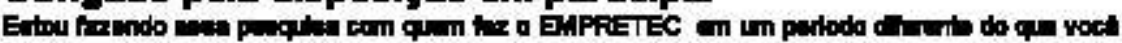
ing

Pondend by

it Google Forms 


\section{APÊNDICE C - CARTA AO SEBRAE}

São Paulo, 30 de agosto de 2016

Sebrae-SP

Coordenação Estadual do Programa EMPRETEC

São Paulo SP

\section{At. Sra. Ana Maria de Araújo Brasílio}

\section{Prezada Senhora}

No ínicio do ano de 2016, iniciei na Faculdade de Economia, Administração e Contabilidade da USP(FEA-USP), como aluno, o Mestrado Profissional em Empreendedorismo, stricto-sensu, cujo comprovante de matricula encaminho em anexo.

Em função da minha experiência como facilitador, fui estimulado por minha orientadora a elaborar um projeto de pesquisa sobre o EMPRETEC, o que prontamente aceitei tendo em vista o vasto material disponivel e as grandes oportunidades de aprendizado e sugestões possiveis.

No primeiro semestre, este projeto de pesquisa foi submetido a diversas avaliações técnicas, e, com diversas contribuições, tanto de professores como de colegas, recebeu a versão atual, cuja cópia encaminho em anexo.

Submeto o projeto a esta Coordenação, no sentido de obter apoio para a realização do mesmo, da seguinte forma:

1. Concordância do Sebrae-SP na utilização do nome da instituição, do nome do programa e da publicação da dissertação final;

2. Contribuiçōes e sugestöes, na etapa da pesquisa qualitativa descrita no projeto, na formação das questões que serão feitas aos participantes do programa na fase quantitativa;

3. Envio do link do endereço eletrônico da pesquisa quantitativa a ser realizada com participantes que fizeram o programa a partir de 2012.

Fico à disposição para esclarecimentos adicionais, e no aguardo de uma breve deliberaçẫo sobre 0 assunto.

Desde já agradeço $\mathrm{a}$ atenção<smiles>[14CH3]</smiles>

Rui Sérgio Torres 
ANEXO A - RESPOSTA DO SEBRAE

$23 / 06 / 2018$

Gmall - Dissertaçbes sobre o Empretec

M Gmail

Rui Torres <rui sergio.torres ggmail.com>

\section{Dissertações sobre o Empretec}

Ana Maria de Araujo Brasilio <anamariab(esp. sebrae.com br>

3 de outubro de 2016 15:42

Para: Rui Torres <nui.sergio.torres@gmail.com>

Oi Rui tudo bom ?

Desculpe a demora, fiquei em atividade externa e nâo consegui te responder.

Referente as solicitaçōes dos 02 primeiros itens estão ok, autorizados.

O uso da logomarca do Empretec somente na condiçāo de destacar que o SEBRAE é a única instituição no Brasil que possuí a exclusividade de aplicar o curso empretec.

Sobre o item 3 fornecimento e utilizaçäo do mailing dos participantes no empretec, não será possível disponibilizar -

Rui consegue dar andamento ao projeto?

Fico no aguardo.

Att.

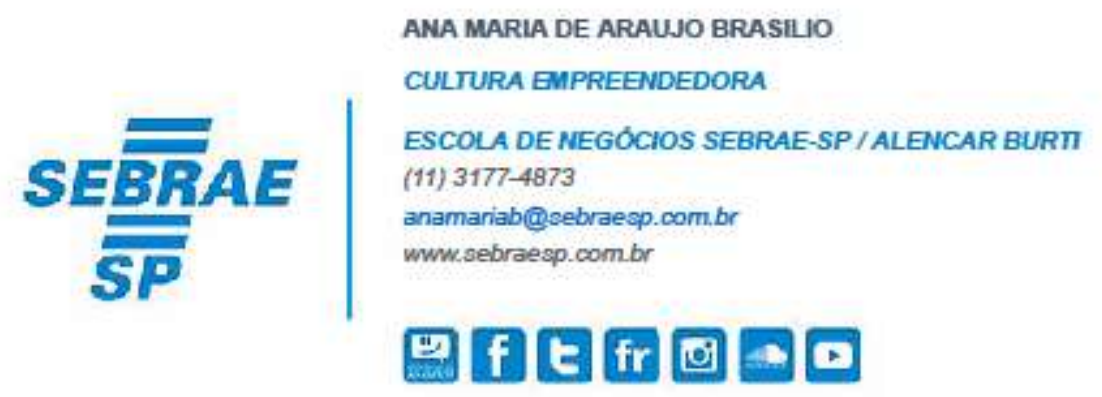

De: Rui Torres [mailto:nui.sergio.torres@gmail.com]

Enviada em: segunda-feira, 3 de outubro de 2016 10:40

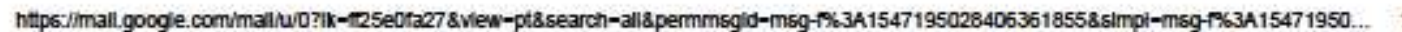




\section{CENTRO DE ESTATÍSTICA APLICADA - CEA - USP RELATÓRIO DE CONSULTA}

TíTULO: "Estudo de impacto do programa de treinamento comportamental em empreendedorismo - EMPRETEC"

PESQUISADOR: Rui Sérgio Torres

ORIENTADORA: Prof ${ }^{a}$ Dra $^{a}$ Lisete Barlach

INSTITUIÇÃO: Faculdade de Economia, Administração e Contabilidade - FEA

FINALIDADE DO PROJETO: Mestrado

PARTICIPANTES DA CONSULTA: Adriana Marques Maia

Carlos Eduardo Barbosa Bastos da Silva Júlia Maria Pavan Soler Mônica Carneiro Sandoval

Rui Sérgio Torres

DATA: 06/03/2018

FINALIDADE DA CONSULTA: Responder questionamentos sobre algumas análises já realizadas dos dados e avaliar propostas adicionais de análise.

RELATÓRIO ELABORADO POR: Adriana Marques Maia

Carlos Eduardo Barbosa Bastos da Silva 


\section{Sumário}

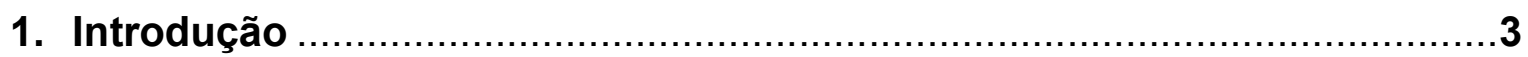

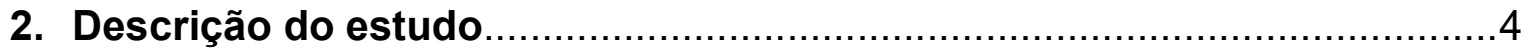

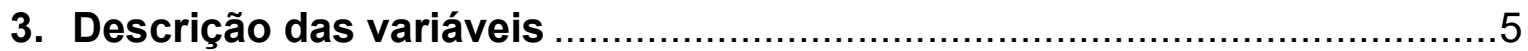

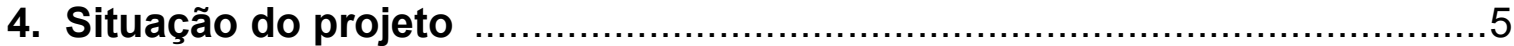

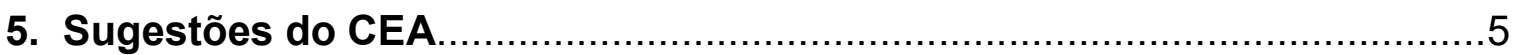

5.1. Questionamentos do Pesquisador.......................................... 5

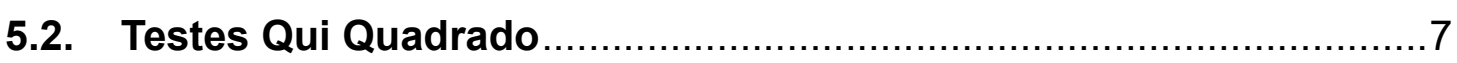

5.3. Tabelas de Contingência e Análise de Correspondência ...............10

5.4. Intervalos de Confiança para Proporções ................................... 11

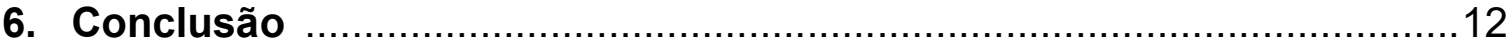

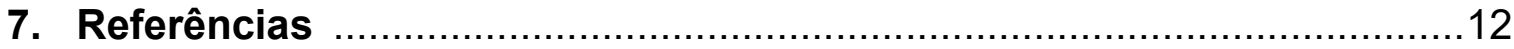

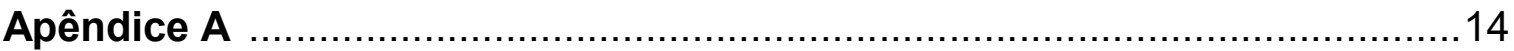

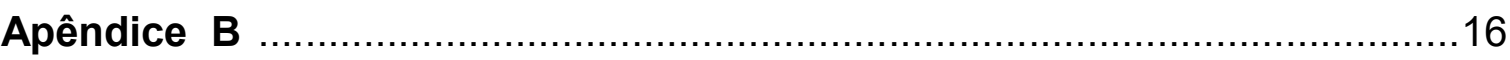

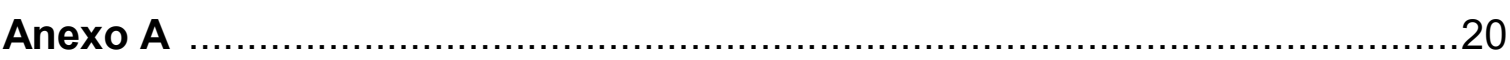

1. Introdução

De acordo com 0 Portal $\quad$ Sebrae (http:// http://www.sebrae.com.br/sites/PortalSebrae), pode-se entender como empreendedor aquele que inicia algo novo, que vê o que ninguém vê, enfim, aquele que realiza antes, aquele que sai da área do sonho, do desejo, e parte para a ação. Ser empreendedor significa ser um realizador que produz novas ideias através da congruência entre criatividade e imaginação. 
Dessa forma, para se tornar um empreendedor de sucesso basta reunir a imaginação com determinação, habilidade de organizar, habilidade de liderar pessoas e habilidade de conhecer tecnicamente etapas e processos. Dentro desses conceitos temos o EMPRETEC.

O EMPRETEC é uma metodologia da Organização das Nações Unidas - ONU - voltada para o desenvolvimento de características de comportamento empreendedor e para a identificação de novas oportunidades de negócios e foi promovida em cerca de 40 países. No Brasil, a metodologia é realizada exclusivamente pelo Sebrae, que já capacitou cerca de 250 mil pessoas, em mais de 10 mil turmas distribuídas pelos 27 Estados da Federação.

Como funciona essa metodologia? São $60 \mathrm{~h}$ de capacitação em seis dias de imersão em que o participante é desafiado em atividades práticas, cientificamente fundamentadas e que apontam como um empreendedor de sucesso age, tendo como base 10 características comportamentais:

1. Busca de oportunidade e iniciativa

2. Persistência

3. Correr riscos calculados

4. Exigência de qualidade e eficiência

5. Comprometimento

6. Busca de informações

7. Estabelecimento de metas

8. Planejamento e monitoramento sistemáticos

9. Persuasão e rede de contatos

10. Independência e autoconfiança

Para participar, um candidato deve procurar o Sebrae do estado onde reside ou ligar na central e inscrever-se para a seleção. Em seguida, agendar uma entrevista, a qual será composta de perguntas sobre situações de seu cotidiano. Somente após, o entrevistador informará se o candidato está apto ou não para participar do Seminário do EMPRETEC, podendo então se matricular.

Dentro do curso do EMPRETEC existem três perfis de pessoas: as que já empreendem; as que querem empreender e têm projeto; e, as que querem empreender e não têm um projeto. Conhecendo esses perfis, foi realizado um questionário em que os empretecos - participantes do curso - respondem sobre eles mesmos e seu empreendimento (etapa 1 do questionário), sobre comportamentos empreendedores (etapa 2) e sobre gestão do próprio empreendimento (etapa 3). 
Nesse sentido, o objetivo geral desse estudo é avaliar o impacto do programa EMPRETEC nos seus participantes através da prática de comportamentos empreendedores. A finalidade desta consulta é responder questionamentos sobre algumas análises já realizadas dos dados e avaliar propostas adicionais de análise comparando as etapas 1 e 2 e as etapas 2 e 3 do questionário.

\section{Descrição do estudo}

O questionário aplicado foi inserido no aplicativo Google Forms considerando resultados de uma pesquisa qualitativa realizada previamente pelo pesquisador. Depois de pronto foi disparado para aproximadamente 1200 pessoas, das quais 307 responderam. Dessas 307 respostas, 42 foram excluídas totalizando em 265 respostas válidas para a análise.

O questionário (Anexo $A$ ) está dividido em 3 partes, chamadas de etapas. $A$ etapa 1 consiste em coletar dados da empresa e do empreendedor e contém 6 questões de múltipla escolha - algumas com uma alternativa aberta - e 3 questões abertas; a etapa 2, em coletar dados sobre comportamentos empreendedores em que os respondentes especificam seu nível de concordância em 20 afirmações. Foi utilizada uma escala Likert de 5 pontos (1= "nunca", 2="raramente", 3="às vezes", 4="usualmente" e 5="sempre"); já a etapa 3 coletou dados sobre práticas de gestão contendo 10 questões de múltipla escolha sobre o assunto, mas com algumas questões com opção aberta.

Com as 265 respostas válidas, o pesquisador iniciou algumas análises descritivas dos dados, porém trouxe algumas preocupações que estão sintetizadas nas seguintes questões:

a. "Na etapa 2, eu coloquei os números da escala Likert, de 1 a 5, ao lado das classificações (Nunca, Raramente, Às vezes, Usualmente e Sempre) nas instruções, mas não coloquei na sequência. Isso de alguma forma invalida o uso desses dados para uma análise quantitativa?"

b. "Usando a escala de 1 a 5, posso fazer uma média da prática de cada comportamento, em termos percentuais, comparando com um total Ideal (só respostas Sempre)?" 
c. "Dos 265 respondentes, 14 disseram que o EMPRETEC não fez diferença para eles. E seus comportamentos se mostraram muito mais fracos que os demais. Como posso usar isso estatisticamente?"

d. "Quais análises estatísticas posso fazer comparando a etapa 1, em que traço um perfil de gênero, faixa etária, escolaridade, etc, com a etapa 2, da prática autodeclarada dos comportamentos? Ex. Diferenças entre homens e mulheres na prática dos comportamentos?"

e. "Igualmente, como posso comparar as etapas 2 e 3? Exemplo: 0 comportamento "Dedico muitas horas ao negócio" com a questão 13, onde pergunto quantas horas o respondente trabalha por dia."

\section{Descrição das variáveis}

O questionário aplicado na pesquisa está em anexo (Anexo $A$ ) a este relatório com a descrição dos 39 itens avaliados (9 itens na etapa 1, 20 na etapa 2 e 10 na etapa 3).

\section{Situação do projeto}

O projeto está na fase de análise dos dados, sob a responsabilidade do pesquisador.

\section{Sugestões do CEA}

\subsection{Questionamentos do Pesquisador}

a. A escala Likert, proposta em 1932 por Reinsis Likert para medir atitudes e opiniões, é uma escala ordinal de 5 ou 7 pontos. Historicamente, há controvérsias sobre como esses dados devem ser analisados, isto é, se variáveis ordinais, convertidas como números, podem ser analisadas como variáveis quantitativas (calculando-se médias e variâncias). Normam (2010), abordando esse tema, apresenta evidências, com base em dados reais e simulados, de que análises paramétricas são suficientemente robustas e podem ser aplicadas a dados ordinais tais como a escala Likert, porém respeitando-se algumas limitações, principalmente, na conversão e 
interpretação da escala. Por exemplo, a média de uma resposta 5 com duas respostas 2 é 3, mas qual é o significado desse número? Nesse sentido, recomenda-se na análise descritiva dos dados o cálculo de outras medidas de posição, como a moda e a mediana, além da distribuição de frequências das classificações. Deste modo, levando-se em consideração que a escala Likert de 5 pontos foi apresentada nas Instruções do Questionário, estando indexadas às classificações de $1=$ "nunca" a $5=$ "sempre", os dados podem ser tratados como variáveis quantitativas para algumas finalidades de análise, porém devese levar em conta sua natureza ordinal tanto na análise descritiva, como na construção e análise de tabelas de contingência e na interpretação dos resultados.

b. Considerando a conversão numérica da escala ordinal Likert, sim, é possível fazer esse cálculo e estabelecer essa comparação descritiva, contudo, sendo cuidadoso na interpretação dos resultados. Também, para dar mais consistência aos resultados, é interessante calcular outras medidas de posição, como a moda e a mediana, e compará-las com a resposta $5=$ "sempre". Além disso, intervalos de confiança para a média (bem como para a mediana) podem ser calculados, os quais levam em conta a variabilidade dos dados (ver, por exemplo, Bussab e Morettin, 2017). Nesse caso, cuidados devem ser tomados na realização de inferências para a população dos Empretecos com base na amostra coletada, pois, como o plano amostral não foi aleatório, a população caracterizada pelos respondentes do questionário pode ser diferente da população alvo do estudo.

c. Inicialmente, os dois grupos de respondentes (dos 14 citados e dos outros 251), devem ser bem caracterizados por meio da análise descritiva, relativamente às variáveis demográficas além da distribuição de frequências das cinco categorias nas variáveis comportamentais. Além disso, pode ser indicado que, com base nesses resultados (14/265=0,05 x 251/265=0,95), há evidência amostral de que a probabilidade de um respondente dizer que "o EMPRETEC não fez diferença para ele" é significantemente menor que a probabilidade do respondente dizer o contrário. Essa diferença estatisticamente significante pode ser justificada por meio de testes de hipóteses e/ou intervalos de confiança para a probabilidade de sucesso da Binomial, porém, possíveis 
comparações entre esses grupos ficam prejudicadas pelo alto grau de desbalanceamento entre eles (14 × 251 respondentes).

d. Os testes apresentados na Seção 5.2 são um exemplo do tipo de análise que pode ser feita com os dados apresentados. Em geral, busca-se verificar se existe homogeneidade entre, por exemplo, os sexos (uma variável da etapa 1) na distribuição de frequências das categorias (de 1 a 5 ) para as questões apresentadas na etapa 2 ou 3.

e. É possível comparar questões das etapas 2 e 3 por meio da análise de tabelas de contingência com as distribuições de frequências conjuntas. Testes de associação ou homegeneidade, bem como análises de correspondência, podem então ser realizados, conforme exemplo apresentado na Seção 5.3.

\subsection{Testes Qui-Quadrado}

As análises a seguir utilizam o Teste Qui-quadrado para testar a homogeneidade entre os sexos de acordo com a distribuição de frequência das respostas relacionadas a cada uma das questões. Maiores detalhes sobre o uso de testes Qui-quadrado, em estudos de homogeneidade ou associação em tabelas de contingência, podem ser obtidos em Bussab e Morettin (2017).

$\mathrm{Na}$ análise das tabelas de contingência, nos casos em que a frequência de mais do que $20 \%$ das caselas é menor que cinco, utilizamos o Teste Exato de Fisher, conforme recomendado na literatura (Freeman e Halton, 1951). A opção 'Nunca' foi agrupada com a opção 'Raramente', pois não existem observações para a categoria 'Nunca' em algumas perguntas do questionário, impossibilitando a execução do teste.

A Tabela 1 apresenta a descrição das questões de Comportamento analisadas de acordo com o sexo dos respondentes. A seguir são apresentadas as tabelas de distribuição de frequências para cada uma dessas questões com as estatísticas do teste de homogeneidade entre os sexos e os correspondentes valores-p (níveis descritivos do teste).

Tabela 1. Questões de Comportamento.

\begin{tabular}{lc}
\hline Comportamento & Sigla \\
\hline Possuo o conhecimento necessário no ramo escolhido & Q1 \\
Desenvolvo produtos ou serviços para atender às necessidades de mercado & Q2 \\
Dedico muitas horas ao negócio & Q3 \\
Estou fisicamente presente e assumo responsabilidade pela gestão diária do negócio & Q4
\end{tabular}


Demonstro convicção de que o negócio dará certo $\quad$ Q5

Persevero a despeito de obstáculos $\quad$ Q6

$\begin{array}{ll}\text { Penso que sou auto motivado (a) } & \text { Q7 }\end{array}$

Obtenho conselhos de outros $\quad$ Q8

Expando/Expandi o negócio ao identificar novos mercados para os produtos ou serviços $\quad$ Q9

Tabela 2. Distribuição de frequências de Q1 por sexo.

\begin{tabular}{cccccc}
\hline & \multicolumn{5}{c}{ Respostas de Q1 } \\
\cline { 2 - 6 } Sexo & 1. Nunca/Raramente & 2. Às vezes & 3. Usualmente & 4. Sempre & Total \\
\hline M & $4(2 \%)$ & $12(7 \%)$ & $61(36 \%)$ & $93(55 \%)$ & $170(100 \%)$ \\
F & $1(1 \%)$ & $3(3 \%)$ & $37(39 \%)$ & $54(57 \%)$ & $95(100 \%)$ \\
Total & $5(2 \%)$ & $15(6 \%)$ & $98(37 \%)$ & $147(55 \%)$ & $265(100 \%)$ \\
\hline
\end{tabular}

Tabela 3. Distribuição de frequências de Q2 por sexo.

\begin{tabular}{cccccc}
\hline & \multicolumn{5}{c}{ Respostas de Q2 } \\
\cline { 2 - 6 } Sexo & 1. Nunca/Raramente & 2. Às vezes & 3. Usualmente & 4. Sempre & Total \\
\hline M & $6(4 \%)$ & $18(11 \%)$ & $72(42 \%)$ & $74(44 \%)$ & $170(100 \%)$ \\
F & $0(0 \%)$ & $13(14 \%)$ & $32(34 \%)$ & $50(53 \%)$ & $95(100 \%)$ \\
Total & $6(2 \%)$ & $31(12 \%)$ & $104(39 \%)$ & $124(47 \%)$ & $265(100 \%)$ \\
\hline
\end{tabular}

Tabela 4. Distribuição de frequências de Q3 por sexo.

\begin{tabular}{cccccc}
\hline & \multicolumn{5}{c}{ Respostas de Q3 } \\
\cline { 2 - 6 } Sexo & 1. Nunca/Raramente & 2. Às vezes & 3. Usualmente & 4. Sempre & Total \\
\hline M & $6(4 \%)$ & $21(12 \%)$ & $41(24 \%)$ & $102(60 \%)$ & $170(100 \%)$ \\
F & $2(2 \%)$ & $8(8 \%)$ & $32(34 \%)$ & $53(56 \%)$ & $95(100 \%)$ \\
Total & $8(3 \%)$ & $29(11 \%)$ & $73(28 \%)$ & $155(58 \%)$ & $265(100 \%)$ \\
\hline
\end{tabular}

Tabela 5. Distribuição de frequências de Q4 por sexo.

\begin{tabular}{cccccc}
\hline & \multicolumn{5}{c}{ Respostas de Q4 } \\
\cline { 2 - 6 } Sexo & 1. Nunca/Raramente & 2. Às vezes & 3. Usualmente & 4. Sempre & Total \\
\hline M & $7(4 \%)$ & $14(8 \%)$ & $43(25 \%)$ & $106(62 \%)$ & $170(100 \%)$ \\
$F$ & $1(1 \%)$ & $7(7 \%)$ & $22(23 \%)$ & $65(68 \%)$ & $95(100 \%)$ \\
Total & $8(3 \%)$ & $21(8 \%)$ & $65(25 \%)$ & $171(65 \%)$ & $265(100 \%)$ \\
\hline \multicolumn{6}{c}{ Tabela 6.Distribuição de frequências de Q5 por sexo } \\
\hline \multicolumn{6}{c}{ Respostas de Q5 } \\
Sexo & 1. Nunca/Raramente & 2. Às vezes & 3. Usualmente & 4. Sempre & Total \\
\cline { 2 - 6 } M & $6(4 \%)$ & $14(8 \%)$ & $42(25 \%)$ & $108(64 \%)$ & $170(100 \%)$ \\
F & $0(0 \%)$ & $5(5 \%)$ & $29(31 \%)$ & $61(64 \%)$ & $95(100 \%)$ \\
Total & $6(2 \%)$ & $19(7 \%)$ & $71(27 \%)$ & $169(64 \%)$ & $265(100 \%)$ \\
\hline
\end{tabular}


Tabela 7. Distribuição de frequências de Q6 por sexo

\begin{tabular}{cccccc}
\hline & \multicolumn{5}{c}{ Respostas de Q6 } \\
\cline { 2 - 6 } Sexo & 1. Nunca/Raramente & 2. Às vezes & 3. Usualmente & 4. Sempre & Total \\
\hline M & $5(3 \%)$ & $7(4 \%)$ & $55(32 \%)$ & $103(61 \%)$ & $170(100 \%)$ \\
F & $0(0 \%)$ & $4(4 \%)$ & $31(33 \%)$ & $60(63 \%)$ & $95(100 \%)$ \\
Total & $5(2 \%)$ & $11(4 \%)$ & $86(32 \%)$ & $163(62 \%)$ & $265(100 \%)$ \\
\hline
\end{tabular}

Tabela 8. Distribuição de frequências de Q7 por sexo

\begin{tabular}{cccccc}
\hline & \multicolumn{5}{c}{ Respostas de Q7 } \\
\cline { 2 - 6 } Sexo & 1. Nunca/Raramente & 2. Às vezes & 3. Usualmente & 4. Sempre & Total \\
\hline M & $6(4 \%)$ & $28(16 \%)$ & $63(37 \%)$ & $73(43 \%)$ & $170(100 \%)$ \\
F & $0(0 \%)$ & $18(19 \%)$ & $38(40 \%)$ & $39(41 \%)$ & $95(100 \%)$ \\
Total & $6(2 \%)$ & $46(17 \%)$ & $101(38 \%)$ & $112(42 \%)$ & $265(100 \%)$ \\
\hline
\end{tabular}

Tabela 9. Distribuição de frequências de Q8 por sexo

\begin{tabular}{cccccc}
\hline & \multicolumn{5}{c}{ Respostas de Q8 } \\
\cline { 2 - 6 } Sexo & 1. Nunca/Raramente & 2. Às vezes & 3. Usualmente & 4. Sempre & Total \\
\hline M & $7(4 \%)$ & $29(17 \%)$ & $81(48 \%)$ & $53(31 \%)$ & $170(100 \%)$ \\
F & $1(1 \%)$ & $16(17 \%)$ & $43(45 \%)$ & $35(37 \%)$ & $95(100 \%)$ \\
Total & $8(3 \%)$ & $45(17 \%)$ & $124(47 \%)$ & $88(33 \%)$ & $265(100 \%)$ \\
\hline
\end{tabular}

Tabela 10. Distribuição de frequências de Q9 por sexo

\begin{tabular}{cccccc}
\hline \multirow{5}{*}{ Sexo } & \multicolumn{5}{c}{ Respostas de Q9 } \\
\cline { 2 - 6 } M & 1. Nunca/Raramente & 2. Às vezes & 3. Usualmente & 4. Sempre & Total \\
F & $21(12 \%)$ & $33(19 \%)$ & $62(36 \%)$ & $54(32 \%)$ & $170(100 \%)$ \\
Total & $9(9 \%)$ & $18(19 \%)$ & $35(37 \%)$ & $33(35 \%)$ & $95(100 \%)$ \\
\hline
\end{tabular}

Tabela 11. Valores - p (nível descritivo) associados aos testes de homogeneidade para cada questão.

\begin{tabular}{lccccccccc}
\hline & Q1 & Q2 & Q3 & Q4 & Q5 & Q6 & Q7 & Q8 & Q9 \\
\cline { 2 - 10 } $\begin{array}{l}\text { valor - } \\
\mathrm{p}\end{array}$ & 0.5106 & 0.1088 & 0.3234 & 0.4908 & 0.1782 & 0.4285 & 0.2962 & 0.4643 & 0.892 \\
\hline
\end{tabular}

Observação: Os valores-p destacados em amarelo foram gerados pelo teste exato de Fisher.

Adotando um nível de significância de $5 \%$, para todas as questões, os resultados indicam que não há evidência amostral para a rejeição da hipótese de homogeneidade entre os sexos, isto é, não há evidência amostral para diferença significante entre os sexos relativamente ao padrão de respostas das práticas de comportamentos avaliados (Q1 a Q9). 
Os testes Qui-Quadrado foram executados utilizando os recursos do aplicativo SAS, versão 9.4. O Apêndice A apresenta os comandos do procedure freq do SAS para gerar as análises. Estes comandos podem ser usados para realizar análises adicionais (testes Qui-quadrado de homogeneidade ou associação).

\subsection{Tabelas de Contingência e Análise de Correspondência}

A Análise de Correspondência é uma técnica gráfica multidimensional, essencialmente descritiva, útil na representação do padrão de associação entre as variáveis em tabelas de contingência. Maiores detalhes podem ser encontrados em Johnson e Wichern (2007).

Considerando o questionamento "e" feito pelo pesquisador (indicado na Seção 2) foi construída uma tabela de contingência (Tabela 12). A Análise de Associação destes dados é apresentada na Tabela 13, em que, da mesma forma como aplicado e explicado na Seção 5.2, foi utilizado o teste exato de Fisher. As categorias "Nunca" e "Raramente" foram unidas devido à baixa frequência observada. Adotando um nível de significância de $5 \%$, os resultados indicam que há evidência amostral para a rejeição da hipótese de homogeneidade entre as faixas de horas, ou seja, há evidência amostral para diferença significante entre as faixas de horas relativamente ao padrão de respostas da questão (valor-p $<0,001$ ). Adicionalmente, usando os recursos do aplicativo $R$, versão 3.4.4, foi realizada a Análise de Correspondência. O Apêndice $B$ apresenta os comandos do $\mathrm{R}$ usados para gerar as análises.

Tabela 12. Distribuição de frequências das respostas às afirmações "Dedico muitas horas ao meu negócio" e "Quantas horas você trabalha normalmente por dia".

\begin{tabular}{cccccl}
\hline & \multicolumn{5}{c}{ Resposta } \\
\cline { 2 - 6 } Horas & Nunca/Raramente & Às vezes & Usualmente & Sempre & Total \\
\hline $6-8$ & $2(2 \%)$ & $23(27 \%)$ & $31(36 \%)$ & $29(34 \%)$ & $85(100 \%)$ \\
$10-12$ & $6(4 \%)$ & $4(3 \%)$ & $37(25 \%)$ & $100(68 \%)$ & $147(100 \%)$ \\
$14+$ & $0(0 \%)$ & $2(6 \%)$ & $5(15 \%)$ & $26(79 \%)$ & $33(100 \%)$ \\
\hline
\end{tabular}

A Figura 1 mostra os resultados da Análise de Correspondência. Através dela consegue-se visualizar que as faixas de horas "10-12" e "+14" têm perfis de resposta semelhantes, pois seus pontos estão mais próximos, e ambos têm perfis diferentes da faixa "6-8", já que seus pontos estão mais distantes. Considerando as resposta para a escala Likert pode-se observar que as faixas "10-12" e "+14" tendem a estar mais associadas às repostas "sempre", pois seus pontos estão 
mais próximos. Já a faixa "6-12" está mais associada com as respostas "às vezes" e "usualmente".

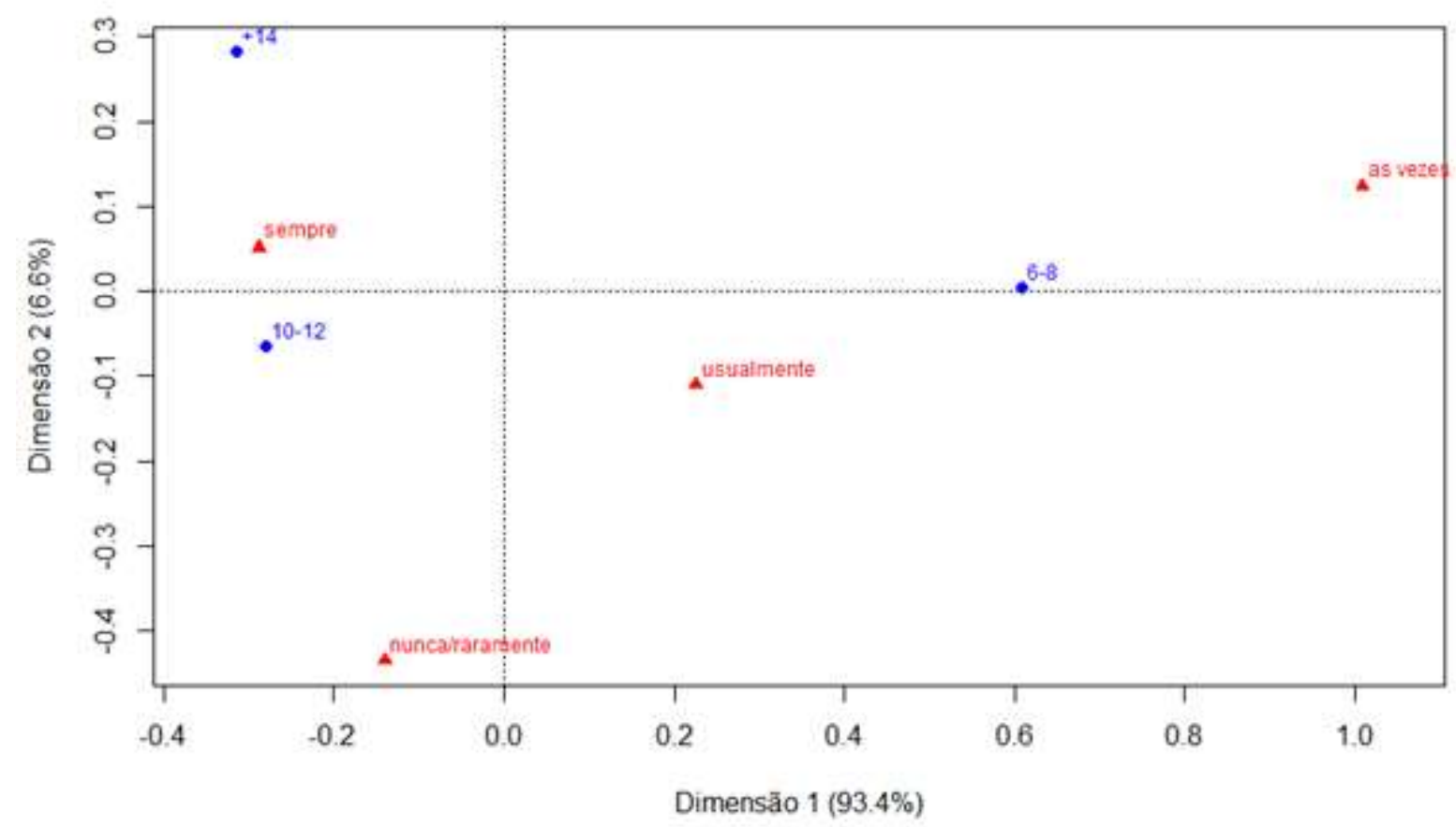

Figura 1. Análise de Correspondência

As duas dimensões apresentadas na Figura 1 são as que representam os dados. Pode-se observar que a variância explicada pela Dimensão 1 é de 93,4\% e que com as duas dimensões a variabilidade total dos dados para essa tabela é explicada.

Essa mesma análise pode ser realizada para outras variáveis entre as etapas 2 e 3.

\subsection{Intervalos de Confiança para Proporções}

Com base nos resultados, há evidência amostral de que a probabilidade ("p") de um respondente dizer que "o EMPRETEC não fez diferença para ele" é significantemente menor que a probabilidade do respondente dizer o contrário; 0 intervalo de confiança para "p" não inclui o valor 0,50.

$$
I C(p) a 95 \%=\hat{p} \pm 1,96 \sqrt{\frac{\hat{p}(1-\hat{p})}{n}}=0,05 \pm 1,96 \sqrt{\frac{0,05 * 0,95}{265}}=(0,024 ; 0,076)
$$

\section{Conclusão}


O pesquisador contatou o CEA para responder algumas questões relacionadas a um questionário aplicado a uma amostra dos participantes de um treinamento voltado ao desenvolvimento de características de comportamento empreendedor.

Os questionamentos apresentados na Seção 2 foram considerados ao longo deste relatório e algumas análises foram realizadas envolvendo a aplicação de testes Qui-quadrado, Análise de Correspondência e Intervalos de Confiança para proporções.

Os testes Qui-quadrado apresentados na Seção 5.2 indicam que não há evidência amostral para diferenças entre os sexos dos entrevistados de acordo com a distribuição de frequências das respostas das questões Q1 a Q9.

A Análise de Correspondência apresentada na Seção 5.3 descreve graficamente os dados dispostos em uma tabela de contingência. Esta análise pode ser aplicada para outras tabelas de contingência construídas entre as variáveis das etapas 2 e 3.

Para a probabilidade de um respondente dizer que "o EMPRETEC não fez diferença para ele", o intervalo de confiança (a 95\%) para proporções indicou que esta é significantemente menor que a probabilidade do respondente dizer o contrário, isto é, que o EMPRETEC fez diferença para ele.

\section{Referências}

[1] JOHNSON, R.A.; WICHERN, D.W. (2007). Applied Multivariate Statistical Analysis. $6^{\text {th }}$.ed.Pearson Education

[2] Empretec: fortaleça suas habilidades como empreendedor. Disponível em: http://www.sebrae.com.br/sites/PortalSebrae/sebraeaz/empretec-fortaleca-suashabilidades-comoempreendedor,db3c36627a963410VgnVCM1000003b74010aRCRD. Acesso em 12/03/2018.

[3] O que é ser empreendedor.

Disponível em:

http://www.sebrae.com.br/sites/PortalSebrae/bis/o-que-e-serempreendedor,ad17080a3e107410VgnVCM1000003b74010aRCRD. Acesso em $12 / 03 / 2018$. 
[4] NORMAN, G. (2010) Likert scales, levels of measurement and the "laws"of statistics. Adv Health Sci Educ Theory Pract 15(5): 625-632.

[5] FREEMAN, G.H.; HALTON, J.H. (1951) Note on exact treatment of contingency, goodness of fit and other problems of significance. Biometrika, 38, 141-149.

[6] Example 3.5 Analysis of a $2 \times 2$ Contingency Table. Disponível em: http://support.sas.com/documentation/cdl/en/procstat/66703/HTML/default/viewer.ht m\#procstat freq examples05.htm. Acesso em 23/03/2018.

[7] BUSSAB, W.O.; MORETTIN, P.A. (2017). Estatística Básica. $9^{\text {th }}$.ed. Editora Saraiva 


\section{APÊNDICE A - Comandos utilizados na Seção 5.2}

Comandos do procedure freq do SAS - versão 9.4 - para gerar as análises:

proc freq data=ruitr order=internal;

tables source ${ }^{*}$ sex ${ }^{*}$ freq / chisq nocol norow nopercent;

exact pchi;

weight Column1;

run;

Dados da base ruitr:

\begin{tabular}{|c|c|c|c|}
\hline Freq & Sex & Source & Column 1 \\
\hline Nunca/Rara & $\mathrm{M}$ & Q1 & 4 \\
\hline Nunca/Rara & $\mathrm{M}$ & $\mathrm{Q} 2$ & 6 \\
\hline Nunca/Rara & $\mathrm{M}$ & Q3 & 0 \\
\hline Nunca/Rara & $\mathrm{M}$ & Q4 & 7 \\
\hline Nunca/Rara & $\mathrm{M}$ & Q5 & 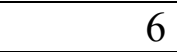 \\
\hline Nunca/Rara & $\mathrm{M}$ & Q6 & 5 \\
\hline Nunca/Rara & $\mathrm{M}$ & Q7 & 6 \\
\hline Nunca/Rara & $\mathrm{M}$ & Q8 & 7 \\
\hline Nunca/Rara & $\mathrm{M}$ & Q9 & 21 \\
\hline Nunca/Rara & $\mathrm{M}$ & Q10 & 9 \\
\hline Nunca/Rara & $M$ & Q11 & 13 \\
\hline Nunca/Rara & $\mathrm{M}$ & Q12 & 5 \\
\hline Nunca/Rara & $\mathrm{M}$ & Q13 & 8 \\
\hline Nunca/Rara & $\mathrm{M}$ & Q14 & 17 \\
\hline Nunca/Rara & $\mathrm{M}$ & Q15 & 21 \\
\hline Nunca/Rara & $\mathrm{M}$ & Q16 & 12 \\
\hline Nunca/Rara & $\mathrm{M}$ & Q17 & 10 \\
\hline Nunca/Rara & $\mathrm{M}$ & Q18 & 4 \\
\hline Nunca/Rara & $\mathrm{M}$ & Q19 & 7 \\
\hline Nunca/Rara & $\mathrm{M}$ & Q20 & 36 \\
\hline Nunca/Rara & $\mathrm{F}$ & Q1 & 1 \\
\hline Nunca/Rara & $\mathrm{F}$ & Q2 & 0 \\
\hline Nunca/Rara & $\mathrm{F}$ & Q3 & 2 \\
\hline Nunca/Rara & $\mathrm{F}$ & Q4 & 1 \\
\hline Nunca/Rara & $\mathrm{F}$ & Q5 & 0 \\
\hline Nunca/Rara & $\mathrm{F}$ & Q6 & 0 \\
\hline Nunca/Rara & $\mathrm{F}$ & Q7 & 0 \\
\hline Nunca/Rara & $\mathrm{F}$ & Q8 & 1 \\
\hline Nunca/Rara & $\mathrm{F}$ & Q9 & 9 \\
\hline Nunca/Rara & $\mathrm{F}$ & Q10 & 6 \\
\hline Nunca/Rara & $\mathrm{F}$ & Q11 & 6 \\
\hline Nunca/Rara & $\mathrm{F}$ & Q12 & 3 \\
\hline Nunca/Rara & $\mathrm{F}$ & Q13 & 7 \\
\hline Nunca/Rara & $\mathrm{F}$ & Q14 & 11 \\
\hline Nunca/Rara & $\mathrm{F}$ & Q15 & 9 \\
\hline
\end{tabular}

\begin{tabular}{|l|l|l|r|} 
Nunca/Rara & F & Q16 & 7 \\
\hline Nunca/Rara & F & Q17 & 3 \\
\hline Nunca/Rara & F & Q18 & 2 \\
\hline Nunca/Rara & F & Q19 & 2 \\
\hline Nunca/Rara & F & Q20 & 18 \\
\hline Sempre & M & Q1 & 93 \\
\hline Sempre & M & Q2 & 74 \\
\hline Sempre & M & Q3 & 102 \\
\hline Sempre & M & Q4 & 106 \\
\hline Sempre & M & Q5 & 108 \\
\hline Sempre & M & Q6 & 103 \\
\hline Sempre & M & Q7 & 73 \\
\hline Sempre & M & Q8 & 53 \\
\hline Sempre & M & Q9 & 54 \\
\hline Sempre & M & Q10 & 62 \\
\hline Sempre & M & Q11 & 58 \\
\hline Sempre & M & Q12 & 57 \\
\hline Sempre & M & Q13 & 63 \\
\hline Sempre & M & Q14 & 78 \\
\hline Sempre & M & Q15 & 86 \\
\hline Sempre & M & Q16 & 70 \\
\hline Sempre & M & Q17 & 71 \\
\hline Sempre & M & Q18 & 59 \\
\hline Sempre & M & Q19 & 52 \\
\hline Sempre & M & Q20 & 23 \\
\hline Sempre & F & Q1 & 54 \\
\hline Sempre & F & Q2 & 50 \\
\hline Sempre & $F$ & Q3 & 53 \\
\hline Sempre & F & Q4 & 65 \\
\hline Sempre & F & Q5 & 61 \\
\hline Sempre & F & Q6 & 60 \\
\hline Sempre & F & Q7 & 39 \\
\hline Sempre & F & Q8 & 35 \\
\hline Sempre & F & Q9 & 33 \\
\hline Sempre & F & Q10 & 27 \\
\hline Sempre & F & Q11 & 27 \\
\hline
\end{tabular}




\begin{tabular}{|c|c|c|c|}
\hline Sempre & $\mathrm{F}$ & Q12 & 29 \\
\hline Sempre & $\mathrm{F}$ & Q13 & 28 \\
\hline Sempre & $\mathrm{F}$ & Q14 & 37 \\
\hline Sempre & $\mathrm{F}$ & Q15 & 45 \\
\hline Sempre & $\mathrm{F}$ & Q16 & 41 \\
\hline Sempre & $\mathrm{F}$ & Q17 & 47 \\
\hline Sempre & $\mathrm{F}$ & Q18 & 41 \\
\hline Sempre & $\mathrm{F}$ & Q19 & 36 \\
\hline Sempre & $\mathrm{F}$ & Q20 & 9 \\
\hline Usualmente & $\mathrm{M}$ & Q1 & 61 \\
\hline Usualmente & $\mathrm{M}$ & Q2 & 72 \\
\hline Usualmente & $\mathrm{M}$ & Q3 & 41 \\
\hline Usualmente & $\mathrm{M}$ & Q4 & 43 \\
\hline Usualmente & $\mathrm{M}$ & Q5 & 42 \\
\hline Usualmente & $\mathrm{M}$ & Q6 & 55 \\
\hline Usualmente & $\mathrm{M}$ & Q7 & 63 \\
\hline Usualmente & $\mathrm{M}$ & Q8 & 81 \\
\hline Usualmente & $\mathrm{M}$ & Q9 & 62 \\
\hline Usualmente & $\mathrm{M}$ & Q10 & 70 \\
\hline Usualmente & $\mathrm{M}$ & Q11 & 70 \\
\hline Usualmente & $\mathrm{M}$ & Q12 & 81 \\
\hline Usualmente & $\mathrm{M}$ & Q13 & 68 \\
\hline Usualmente & $\mathrm{M}$ & Q14 & 51 \\
\hline Usualmente & $\mathrm{M}$ & Q15 & 36 \\
\hline Usualmente & $\mathrm{M}$ & Q16 & 60 \\
\hline Usualmente & $\mathrm{M}$ & Q17 & 71 \\
\hline Usualmente & $\mathrm{M}$ & Q18 & 92 \\
\hline Usualmente & $\mathrm{M}$ & Q19 & 91 \\
\hline Usualmente & $\mathrm{M}$ & Q20 & 66 \\
\hline Usualmente & $\mathrm{F}$ & Q1 & 37 \\
\hline Usualmente & $\mathrm{F}$ & Q2 & 32 \\
\hline Usualmente & $\mathrm{F}$ & Q3 & 32 \\
\hline Usualmente & $\mathrm{F}$ & Q4 & 22 \\
\hline Usualmente & $\mathrm{F}$ & Q5 & 29 \\
\hline Usualmente & $\mathrm{F}$ & Q6 & 31 \\
\hline Usualmente & $\mathrm{F}$ & Q7 & 38 \\
\hline Usualmente & $\mathrm{F}$ & Q8 & 43 \\
\hline Usualmente & $\mathrm{F}$ & Q9 & 35 \\
\hline Usualmente & $\mathrm{F}$ & Q10 & 38 \\
\hline Usualmente & $\mathrm{F}$ & Q11 & 45 \\
\hline Usualmente & $\mathrm{F}$ & Q12 & 40 \\
\hline Usualmente & $\mathrm{F}$ & Q13 & 35 \\
\hline Usualmente & $\mathrm{F}$ & Q14 & 32 \\
\hline Usualmente & $\mathrm{F}$ & Q15 & 25 \\
\hline Usualmente & $\mathrm{F}$ & Q16 & 37 \\
\hline
\end{tabular}

\begin{tabular}{|c|c|c|c|}
\hline Usualmente & $\mathrm{F}$ & Q17 & 34 \\
\hline Usualmente & $\mathrm{F}$ & Q18 & 45 \\
\hline Usualmente & $\mathrm{F}$ & Q19 & 49 \\
\hline Usualmente & $\mathrm{F}$ & Q20 & 42 \\
\hline Às vezes & $\mathrm{M}$ & Q1 & 12 \\
\hline Às vezes & $\bar{M}$ & Q2 & 18 \\
\hline Às vezes & $\mathrm{M}$ & Q3 & 21 \\
\hline Às vezes & $\mathrm{M}$ & Q4 & 14 \\
\hline Às vezes & $\mathrm{M}$ & Q5 & 14 \\
\hline Às vezes & $\mathrm{M}$ & Q6 & 7 \\
\hline Às vezes & $\mathrm{M}$ & Q7 & 28 \\
\hline Às vezes & $\mathrm{M}$ & Q8 & 29 \\
\hline Às vezes & $\bar{M}$ & Q9 & 33 \\
\hline Às vezes & $\mathrm{M}$ & Q10 & 29 \\
\hline Às vezes & $\mathrm{M}$ & Q11 & 29 \\
\hline Às vezes & $\mathrm{M}$ & Q12 & 27 \\
\hline Às vezes & $\mathrm{M}$ & Q13 & 31 \\
\hline Às vezes & $\mathrm{M}$ & Q14 & 24 \\
\hline Às vezes & $\mathrm{M}$ & Q15 & 27 \\
\hline Às vezes & $\mathrm{M}$ & Q16 & 28 \\
\hline Às vezes & $\bar{M}$ & Q17 & 18 \\
\hline Às vezes & $\mathrm{M}$ & Q18 & 15 \\
\hline Às vezes & $\mathrm{M}$ & Q19 & 20 \\
\hline Às vezes & $\mathrm{M}$ & Q20 & 45 \\
\hline Às vezes & $\mathrm{F}$ & Q1 & 3 \\
\hline Às vezes & $\mathrm{F}$ & Q2 & 13 \\
\hline Às vezes & $\mathrm{F}$ & Q3 & 8 \\
\hline Às vezes & $\mathrm{F}$ & Q4 & 7 \\
\hline Às vezes & $\mathrm{F}$ & Q5 & 5 \\
\hline Às vezes & $\mathrm{F}$ & Q6 & 4 \\
\hline Às vezes & $\mathrm{F}$ & Q7 & 18 \\
\hline Às vezes & $\mathrm{F}$ & Q8 & 16 \\
\hline Às vezes & $\mathrm{F}$ & Q9 & 18 \\
\hline Às vezes & $\mathrm{F}$ & Q10 & 24 \\
\hline Às vezes & $\mathrm{F}$ & Q11 & 17 \\
\hline Às vezes & $\mathrm{F}$ & Q12 & 23 \\
\hline Às vezes & $\mathrm{F}$ & Q13 & 25 \\
\hline Às vezes & $\mathrm{F}$ & Q14 & 15 \\
\hline Às vezes & $\mathrm{F}$ & Q15 & 16 \\
\hline Às vezes & $\mathrm{F}$ & Q16 & 10 \\
\hline Às vezes & $\mathrm{F}$ & Q17 & 11 \\
\hline Às vezes & $\mathrm{F}$ & Q18 & 7 \\
\hline Às vezes & $\mathrm{F}$ & Q19 & 8 \\
\hline Às vezes & $\mathrm{F}$ & Q20 & 26 \\
\hline
\end{tabular}




\section{APÊNDICE B - Comandos utilizados na Seção 5.3}

Com base nos dados da Tabela 12 foram utilizados os seguintes comandos no aplicativo R - versão 3.4.4 - para executar a Análise de Correspondência:

dados<-matrix $(c(2,6,0,23,4,2,31,37,5,29,100,26)$, nrow=3, ncol=4)

dados<-as.table(dados)

dados

rownames $($ dados $)=c(" 6-8$ ", "10-12", "+14")

colnames(dados)=c("nunca/raramente", "as vezes", "usualmente", "sempre")

dados

prop.table(dados, 1$)$

prop.table(dados,2)

library(ca)

dados $1<-$ ca(dados)

dados 1

plot(dados1, main="Figura 1. Análise de Correspondência", cex.main=0.9, xlab = "Dimensão 1 (93.4\%)", ylab = "Dimensão 2 (6.6\%)")

As informações da tabela 13 foram geradas a partir do aplicativo SAS - versão 9.4 - com o seguinte código:

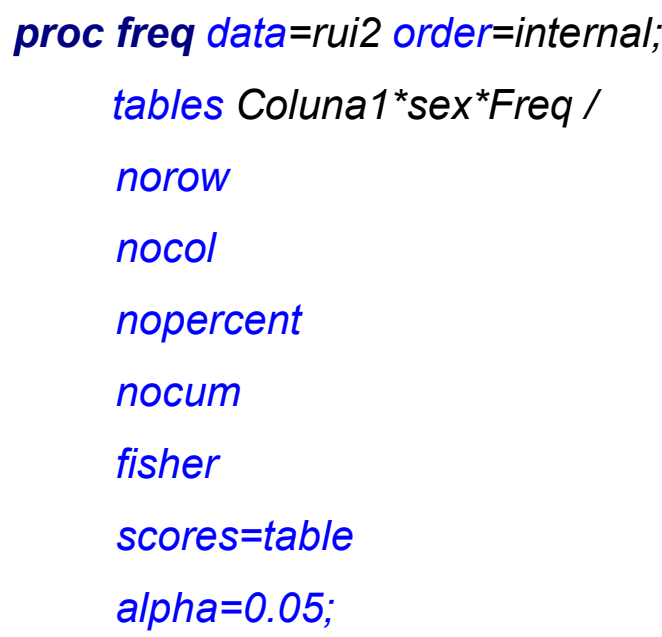

run; 
Dados da base rui2:

\begin{tabular}{|c|c|}
\hline Freq & Coluna1 \\
\hline $\begin{array}{l}1 . \\
\text { Nunca/Raramente }\end{array}$ & 10 a 12 horas \\
\hline $\begin{array}{l}1 . \\
\text { Nunca/Raramente }\end{array}$ & 10 a 12 horas \\
\hline $\begin{array}{l}1 . \\
\text { Nunca/Raramente }\end{array}$ & 10 a 12 horas \\
\hline $\begin{array}{l}1 . \\
\text { Nunca/Raramente }\end{array}$ & 10 a 12 horas \\
\hline $\begin{array}{l}1 . \\
\text { Nunca/Raramente }\end{array}$ & 6 a 8 horas \\
\hline $\begin{array}{l}1 . \\
\text { Nunca/Raramente }\end{array}$ & 10 a 12 horas \\
\hline $\begin{array}{l}1 . \\
\text { Nunca/Raramente }\end{array}$ & 6 a 8 horas \\
\hline $\begin{array}{l}1 . \\
\text { Nunca/Raramente }\end{array}$ & 10 a 12 horas \\
\hline 2. Às vezes & 10 a 12 horas \\
\hline 2. Às vezes & 6 a 8 horas \\
\hline 2. Às vezes & 6 a 8 horas \\
\hline 2. Às vezes & 6 a 8 horas \\
\hline 2. Às vezes & 6 a 8 horas \\
\hline 2. Às vezes & 6 a 8 horas \\
\hline 2. Às vezes & 6 a 8 horas \\
\hline 2. Às vezes & 6 a 8 horas \\
\hline 2. Às vezes & 10 a 12 horas \\
\hline 2. Às vezes & 10 a 12 horas \\
\hline 2. Às vezes & 6 a 8 horas \\
\hline 2. Às vezes & 6 a 8 horas \\
\hline 2. Às vezes & 6 a 8 horas \\
\hline 2. Às vezes & 10 a 12 horas \\
\hline 2. Às vezes & 6 a 8 horas \\
\hline 2. Às vezes & 14 horas ou mais \\
\hline 2. Às vezes & 6 a 8 horas \\
\hline 2. Às vezes & 6 a 8 horas \\
\hline 2. Às vezes & 6 a 8 horas \\
\hline 2. Às vezes & 6 a 8 horas \\
\hline 2. Às vezes & 6 a 8 horas \\
\hline 2. Às vezes & 6 a 8 horas \\
\hline 2. Às vezes & 6 a 8 horas \\
\hline 2. Às vezes & 14 horas ou mais \\
\hline 2. Às vezes & 6 a 8 horas \\
\hline 2. Às vezes & 6 a 8 horas \\
\hline 2. Às vezes & 6 a 8 horas \\
\hline 2. Às vezes & 6 a 8 horas \\
\hline 2. Às vezes & 6 a 8 horas \\
\hline
\end{tabular}

\begin{tabular}{|c|c|}
\hline 3. Usualmente & 10 a 12 horas \\
\hline 3. Usualmente & 10 a 12 horas \\
\hline 3. Usualmente & 6 a 8 horas \\
\hline 3. Usualmente & 6 a 8 horas \\
\hline 3. Usualmente & 10 a 12 horas \\
\hline 3. Usualmente & 10 a 12 horas \\
\hline 3. Usualmente & 10 a 12 horas \\
\hline 3. Usualmente & 10 a 12 horas \\
\hline 3. Usualmente & 10 a 12 horas \\
\hline 3. Usualmente & 10 a 12 horas \\
\hline 3. Usualmente & 10 a 12 horas \\
\hline 3. Usualmente & 6 a 8 horas \\
\hline 3. Usualmente & 10 a 12 horas \\
\hline 3. Usualmente & 10 a 12 horas \\
\hline 3. Usualmente & 6 a 8 horas \\
\hline 3. Usualmente & 10 a 12 horas \\
\hline 3. Usualmente & 6 a 8 horas \\
\hline 3. Usualmente & 10 a 12 horas \\
\hline 3. Usualmente & 10 a 12 horas \\
\hline 3. Usualmente & 10 a 12 horas \\
\hline 3. Usualmente & 6 a 8 horas \\
\hline 3. Usualmente & 10 a 12 horas \\
\hline 3. Usualmente & 6 a 8 horas \\
\hline 3. Usualmente & 6 a 8 horas \\
\hline 3. Usualmente & 6 a 8 horas \\
\hline 3. Usualmente & 10 a 12 horas \\
\hline 3. Usualmente & 6 a 8 horas \\
\hline 3. Usualmente & 10 a 12 horas \\
\hline 3. Usualmente & 6 a 8 horas \\
\hline 3. Usualmente & 14 horas ou mais \\
\hline 3. Usualmente & 6 a 8 horas \\
\hline 3. Usualmente & 10 a 12 horas \\
\hline 3. Usualmente & 6 a 8 horas \\
\hline 3. Usualmente & 10 a 12 horas \\
\hline 3. Usualmente & 10 a 12 horas \\
\hline 3. Usualmente & 6 a 8 horas \\
\hline 3. Usualmente & 10 a 12 horas \\
\hline 3. Usualmente & 10 a 12 horas \\
\hline 3. Usualmente & 14 horas ou mais \\
\hline 3. Usualmente & 10 a 12 horas \\
\hline 3. Usualmente & 6 a 8 horas \\
\hline 3. Usualmente & 10 a 12 horas \\
\hline 3. Usualmente & 6 a 8 horas \\
\hline 3. Usualmente & 6 a 8 horas \\
\hline 3. Usualmente & 6 a 8 horas \\
\hline
\end{tabular}




\begin{tabular}{|c|c|}
\hline 3. Usualmente & 6 a 8 horas \\
\hline 3. Usualmente & 6 a 8 horas \\
\hline 3. Usualmente & 10 a 12 horas \\
\hline 3. Usualmente & 6 a 8 horas \\
\hline 3. Usualmente & 6 a 8 horas \\
\hline 3. Usualmente & 6 a 8 horas \\
\hline 3. Usualmente & 10 a 12 horas \\
\hline 3. Usualmente & 10 a 12 horas \\
\hline 3. Usualmente & 6 a 8 horas \\
\hline 3. Usualmente & 6 a 8 horas \\
\hline 3. Usualmente & 6 a 8 horas \\
\hline 3. Usualmente & 10 a 12 horas \\
\hline 3. Usualmente & 10 a 12 horas \\
\hline 3. Usualmente & 10 a 12 horas \\
\hline 3. Usualmente & 6 a 8 horas \\
\hline 3. Usualmente & 14 horas ou mais \\
\hline 3. Usualmente & 10 a 12 horas \\
\hline 3. Usualmente & 14 horas ou mais \\
\hline 3. Usualmente & 10 a 12 horas \\
\hline 3. Usualmente & 10 a 12 horas \\
\hline 3. Usualmente & 10 a 12 horas \\
\hline 3. Usualmente & 14 horas ou mais \\
\hline 3. Usualmente & 6 a 8 horas \\
\hline 3. Usualmente & 6 a 8 horas \\
\hline 3. Usualmente & 10 a 12 horas \\
\hline 3. Usualmente & 10 a 12 horas \\
\hline 3. Usualmente & 6 a 8 horas \\
\hline 3. Usualmente & 6 a 8 horas \\
\hline 4. Sempre & 10 a 12 horas \\
\hline 4. Sempre & 10 a 12 horas \\
\hline 4. Sempre & 10 a 12 horas \\
\hline 4. Sempre & 10 a 12 horas \\
\hline 4. Sempre & 14 horas ou mais \\
\hline 4. Sempre & 14 horas ou mais \\
\hline 4. Sempre & 10 a 12 horas \\
\hline 4. Sempre & 10 a 12 horas \\
\hline 4. Sempre & 10 a 12 horas \\
\hline 4. Sempre & 10 a 12 horas \\
\hline 4. Sempre & 6 a 8 horas \\
\hline 4. Sempre & 6 a 8 horas \\
\hline 4. Sempre & 10 a 12 horas \\
\hline 4. Sempre & 10 a 12 horas \\
\hline 4. Sempre & 6 a 8 horas \\
\hline 4. Sempre & 10 a 12 horas \\
\hline 4. Sempre & 10 a 12 horas \\
\hline 4. Sempre & 10 a 12 horas \\
\hline
\end{tabular}

\begin{tabular}{|c|c|}
\hline 4. Sempre & 10 a 12 horas \\
\hline 4. Sempre & 10 a 12 horas \\
\hline 4. Sempre & 14 horas ou mais \\
\hline 4. Sempre & 10 a 12 horas \\
\hline 4. Sempre & 10 a 12 horas \\
\hline 4. Sempre & 6 a 8 horas \\
\hline 4. Sempre & 10 a 12 horas \\
\hline 4. Sempre & 10 a 12 horas \\
\hline 4. Sempre & 10 a 12 horas \\
\hline 4. Sempre & 10 a 12 horas \\
\hline 4. Sempre & 14 horas ou mais \\
\hline 4. Sempre & 10 a 12 horas \\
\hline 4. Sempre & 10 a 12 horas \\
\hline 4. Sempre & 10 a 12 horas \\
\hline 4. Sempre & 10 a 12 horas \\
\hline 4. Sempre & 10 a 12 horas \\
\hline 4. Sempre & 6 a 8 horas \\
\hline 4. Sempre & 10 a 12 horas \\
\hline 4. Sempre & 10 a 12 horas \\
\hline 4. Sempre & 10 a 12 horas \\
\hline 4. Sempre & 14 horas ou mais \\
\hline 4. Sempre & 6 a 8 horas \\
\hline 4. Sempre & 14 horas ou mais \\
\hline 4. Sempre & 6 a 8 horas \\
\hline 4. Sempre & 10 a 12 horas \\
\hline 4. Sempre & 10 a 12 horas \\
\hline 4. Sempre & 14 horas ou mais \\
\hline 4. Sempre & 14 horas ou mais \\
\hline 4. Sempre & 10 a 12 horas \\
\hline 4. Sempre & 14 horas ou mais \\
\hline 4. Sempre & 10 a 12 horas \\
\hline 4. Sempre & 10 a 12 horas \\
\hline 4. Sempre & 6 a 8 horas \\
\hline 4. Sempre & 6 a 8 horas \\
\hline 4. Sempre & 14 horas ou mais \\
\hline 4. Sempre & 10 a 12 horas \\
\hline 4. Sempre & 10 a 12 horas \\
\hline 4. Sempre & 10 a 12 horas \\
\hline 4. Sempre & 6 a 8 horas \\
\hline 4. Sempre & 10 a 12 horas \\
\hline 4. Sempre & 10 a 12 horas \\
\hline 4. Sempre & 14 horas ou mais \\
\hline 4. Sempre & 10 a 12 horas \\
\hline 4. Sempre & 10 a 12 horas \\
\hline 4. Sempre & 6 a 8 horas \\
\hline 4. Sempre & 6 a 8 horas \\
\hline
\end{tabular}




\begin{tabular}{|c|c|}
\hline 4. Sempre & 14 horas ou mais \\
\hline 4. Sempre & 10 a 12 horas \\
\hline 4. Sempre & 10 a 12 horas \\
\hline 4. Sempre & 10 a 12 horas \\
\hline 4. Sempre & 10 a 12 horas \\
\hline 4. Sempre & 14 horas ou mais \\
\hline 4. Sempre & 6 a 8 horas \\
\hline 4. Sempre & 10 a 12 horas \\
\hline 4. Sempre & 10 a 12 horas \\
\hline 4. Sempre & 10 a 12 horas \\
\hline 4. Sempre & 6 a 8 horas \\
\hline 4. Sempre & 10 a 12 horas \\
\hline 4. Sempre & 14 horas ou mais \\
\hline 4. Sempre & 10 a 12 horas \\
\hline 4. Sempre & 10 a 12 horas \\
\hline 4. Sempre & 6 a 8 horas \\
\hline 4. Sempre & 10 a 12 horas \\
\hline 4. Sempre & 10 a 12 horas \\
\hline 4. Sempre & 10 a 12 horas \\
\hline 4. Sempre & 14 horas ou mais \\
\hline 4. Sempre & 6 a 8 horas \\
\hline 4. Sempre & 10 a 12 horas \\
\hline 4. Sempre & 10 a 12 horas \\
\hline 4. Sempre & 10 a 12 horas \\
\hline 4. Sempre & 6 a 8 horas \\
\hline 4. Sempre & 10 a 12 horas \\
\hline 4. Sempre & 6 a 8 horas \\
\hline 4. Sempre & 14 horas ou mais \\
\hline 4. Sempre & 10 a 12 horas \\
\hline 4. Sempre & 10 a 12 horas \\
\hline 4. Sempre & 6 a 8 horas \\
\hline 4. Sempre & 10 a 12 horas \\
\hline 4. Sempre & 10 a 12 horas \\
\hline 4. Sempre & 10 a 12 horas \\
\hline 4. Sempre & 6 a 8 horas \\
\hline 4. Sempre & 10 a 12 horas \\
\hline 4. Sempre & 10 a 12 horas \\
\hline 4. Sempre & 10 a 12 horas \\
\hline 4. Sempre & 10 a 12 horas \\
\hline 4. Sempre & 10 a 12 horas \\
\hline 4. Sempre & 6 a 8 horas \\
\hline 4. Sempre & 6 a 8 horas \\
\hline 4. Sempre & 10 a 12 horas \\
\hline 4. Sempre & 10 a 12 horas \\
\hline 4. Sempre & 10 a 12 horas \\
\hline 4. Sempre & 6 a 8 horas \\
\hline
\end{tabular}

\begin{tabular}{|c|c|}
\hline 4. Sempre & 6 a 8 horas \\
\hline 4. Sempre & 10 a 12 horas \\
\hline 4. Sempre & 10 a 12 horas \\
\hline 4. Sempre & 10 a 12 horas \\
\hline 4. Sempre & 10 a 12 horas \\
\hline 4. Sempre & 14 horas ou mais \\
\hline 4. Sempre & 10 a 12 horas \\
\hline 4. Sempre & 10 a 12 horas \\
\hline 4. Sempre & 14 horas ou mais \\
\hline 4. Sempre & 6 a 8 horas \\
\hline 4. Sempre & 10 a 12 horas \\
\hline 4. Sempre & 10 a 12 horas \\
\hline 4. Sempre & 10 a 12 horas \\
\hline 4. Sempre & 14 horas ou mais \\
\hline 4. Sempre & 14 horas ou mais \\
\hline 4. Sempre & 10 a 12 horas \\
\hline 4. Sempre & 10 a 12 horas \\
\hline 4. Sempre & 10 a 12 horas \\
\hline 4. Sempre & 10 a 12 horas \\
\hline 4. Sempre & 10 a 12 horas \\
\hline 4. Sempre & 10 a 12 horas \\
\hline 4. Sempre & 10 a 12 horas \\
\hline 4. Sempre & 10 a 12 horas \\
\hline 4. Sempre & 6 a 8 horas \\
\hline 4. Sempre & 14 horas ou mais \\
\hline 4. Sempre & 14 horas ou mais \\
\hline 4. Sempre & 14 horas ou mais \\
\hline 4. Sempre & 10 a 12 horas \\
\hline 4. Sempre & 14 horas ou mais \\
\hline 4. Sempre & 10 a 12 horas \\
\hline 4. Sempre & 10 a 12 horas \\
\hline 4. Sempre & 10 a 12 horas \\
\hline 4. Sempre & 10 a 12 horas \\
\hline 4. Sempre & 10 a 12 horas \\
\hline 4. Sempre & 10 a 12 horas \\
\hline 4. Sempre & 10 a 12 horas \\
\hline 4. Sempre & 10 a 12 horas \\
\hline 4. Sempre & 10 a 12 horas \\
\hline 4. Sempre & 14 horas ou mais \\
\hline 4. Sempre & 6 a 8 horas \\
\hline 4. Sempre & 10 a 12 horas \\
\hline 4. Sempre & 6 a 8 horas \\
\hline 4. Sempre & 6 a 8 horas \\
\hline 4. Sempre & 14 horas ou mais \\
\hline 4. Sempre & 10 a 12 horas \\
\hline
\end{tabular}


